Florida International University FIU Digital Commons

3-20-2014

\title{
China's Military Modernization, Japan's Normalization and its Effects on the South China Sea Territorial Disputes
}

Zenel Garcia

zgarc001@fiu.edu

DOI: $10.25148 /$ etd.FI14040898

Follow this and additional works at: https:// digitalcommons.fiu.edu/etd

Part of the Asian Studies Commons, Defense and Security Studies Commons, International $\underline{\text { Relations Commons, Military and Veterans Studies Commons, and the Political Theory Commons }}$

\section{Recommended Citation}

Garcia, Zenel, "China's Military Modernization, Japan's Normalization and its Effects on the South China Sea Territorial Disputes" (2014). FIU Electronic Theses and Dissertations. 1315.

https://digitalcommons.fiu.edu/etd/1315 


\section{FLORIDA INTERNATIONAL UNIVERSITY}

Miami, Florida

\section{CHINA'S MILITARY MODERNIZATION, JAPAN'S NORMALIZATION AND ITS EFFECTS ON THE SOUTH CHINA SEA TERRITORIAL DISPUTES}

A thesis submitted in partial fulfillment of

the requirements for the degree of

MASTER OF ARTS

in

ASIAN STUDIES

by

Zenel Garcia 
To: Dean Kenneth G. Furton

College of Arts and Sciences

This thesis, written by Zenel Garcia, and entitled China's Military Modernization, Japan's Normalization and its Effects on the South China Sea Disputes, having been approved in respect to style and intellectual content, is referred to you for judgment.

We have read this thesis and recommend that it be approved.

Steven Heine

Jin Zeng

Thomas Breslin, Major Professor

Date of Defense: 3/20/2014

The thesis of Zenel Garcia is approved.

Dean Kenneth G. Furton

College of Arts and Sciences

Dean Lakshmi N. Reddi

University Graduate School

Florida International University, 2014 


\section{DEDICATION}

I dedicate this thesis to my mother and grandmother who have been supportive of my academic endeavors for many years. Without their love and support I would not have been able to accomplish the things that I have thus far. 


\section{ACKNOWLEDGMENTS}

I am grateful to my committee which has been instrumental in the development and completion of this study. I thank my major advisor, Dr. Thomas Breslin, for his endless support and providing me with much-needed counsel and research material. Without his assistance this research would not have come to fruition. I would also like to thank Dr. Mohiaddin Mesbahi for his guidance and helping me formulate the framework for this study. I'd also like to thank Dr. Steven Heine whose assistance in research methodology was vital in putting this thesis together. Finally, I am thankful to Dr. Jin Zeng for accepting my request to participate in this committee at the $11^{\text {th }}$ hour and providing valuable feedback and insight that proved valuable for my final draft. I am thankful for the support and encouragement that I have received throughout this process, not only by my committee, but also from the Asian Studies and International Relations Department faculty and staff. Their kind words of encouragement made a world of difference. 


\author{
ABSTRACT OF THE THESIS \\ CHINA’S MILITARY MODERNIZATION, JAPAN’S NORMALIZATION \\ AND ITS EFFECTS ON THE SOUTH CHINA SEA TERRITORIAL DISPUTES \\ by \\ Zenel Garcia
}

Florida International University 2014

Miami, Florida

Professor Thomas Breslin, Major Professor

China’s military modernization has allowed it to take a more assertive position on the territorial disputes it currently has with Japan and its Southeast Asian neighbors. The South China Sea (SCS) dispute is a clear example. Meanwhile, Japan is normalizing its military status to play a more proactive security role in the region. Japan's normalization process has been greatly influenced by China's growing military capabilities as it fears that China could pose a threat to its sea lanes of communications. Although Japan does not have territorial claims in the SCS, it regards the SCS as a strategically vital area. It is this particular concern that has brought Japan into the current territorial disputes in the SCS. This thesis analyzes how Japan has tried to forge partnerships with Southeast Asian countries in the form of foreign aid and the provision of military equipment and training that can potentially offset China's assertiveness. 


\section{TABLE OF CONTENTS}

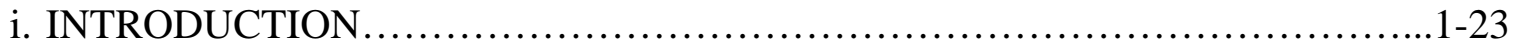

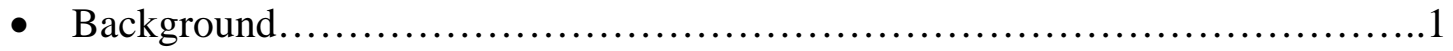

- Marine Superhighway........................................................

- Energy Deposits................................................................

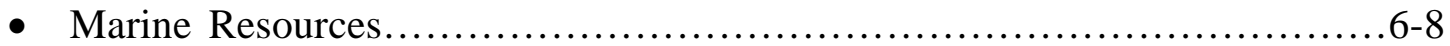

- The South China Sea Disputes.............................................

o China...........................................................

o The Philippines....................................................

o Vietnam.....................................................

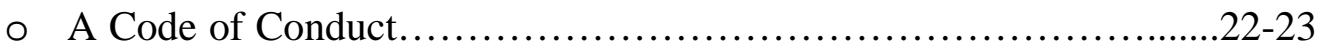

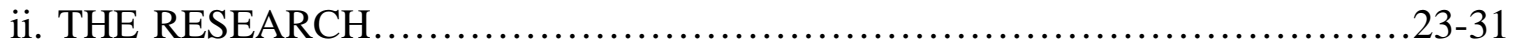

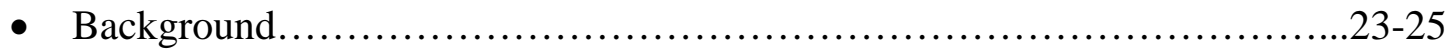

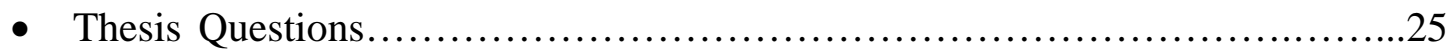

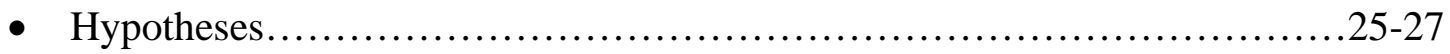

- Methodology, Theoretical Framework, and Structure..........................28-31

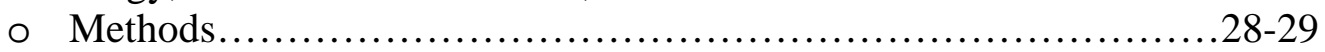

o Theoretical Framework.........................................29-30

o Structure and Organization....................................

I. SINO-JAPANESE SECURITY RELATIONS......................................31-40

- Historical Legacy............................................................

- Chinese Security Perceptions of Japan........................................33-36

- Japanese Security Perceptions of China......................................36-40

II. CHINA'S MILITARY MODERNIZATION.................................40-56

- Background...................................................................

- Catalysts for Modernization................................................41-43

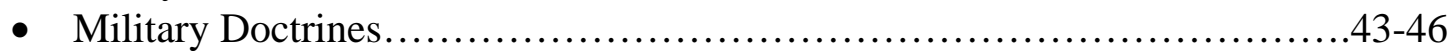

- Acquisitions and Indigenous Production.....................................46-48

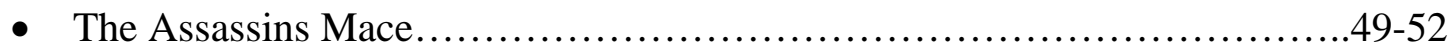

- China's South China Sea Policy...........................................52-56

III. JAPANESE NORMALIZATION..............................................56-75

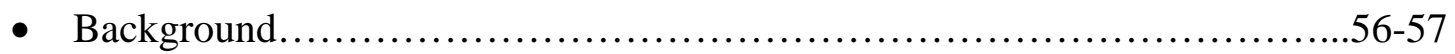

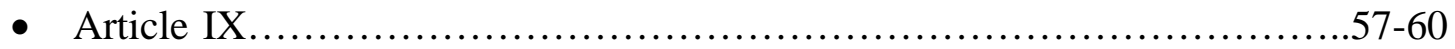

- The Normalization Process......................................................60-65

- Capabilities of the JSDF......................................................65-66

o Ground Forces.................................................66-67 
o Naval Forces.................................................67-71

o Air Forces........................................................... 72

- Japan’s South China Sea Policy.....................................72-75

IV. REPUBLIC OF THE PHILIPPINES CASE STUDY ..........................76-90

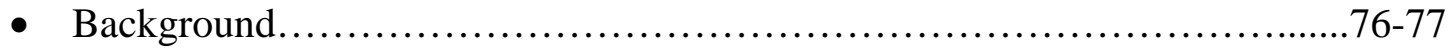

- Energy Resources....................................................... 78

- Marine Resources...................................................... 79

- Strategic Value..........................................................79-80

- Sino-Philippine Disputes.............................................80-82

- The West Philippine Sea.............................................82-83

- AFP Modernization.....................................................83-86

- Japan-Philippine Relations........................................86-90

V. SOCIALIST REPUBLIC OF VIETNAM CASE STUDY .......................91-107

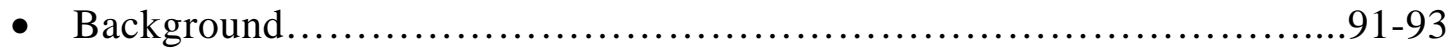

- Energy Resources...................................................93-95

- Marine Resources....................................................95-96

- Sino-Vietnamese Disputes.........................................96-100

- VPA Modernization..................................................100-103

- Japan-Vietnamese Relations.........................................103-107

VI. CONCLUSION......................................................107-131

- Japan and Southeast Asia..........................................107-108

- China and Japan: Growing Enmity..................................108-113

- Securitizing China................................................113-118

- De-securitizing Japan.............................................118-122

- $\quad$ RSCT and Predictive Scenarios.....................................122-125

o Scenario \#1...................................................125-127

o Scenario \#2.......................................................127-129

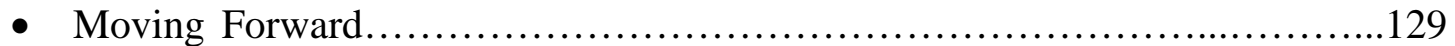

- Further Research.....................................................126-131

LIST OF REFERENCES..............................................132-146 


\section{LIST OF MAPS AND FIGURES}

MAP 1: SCS daily oil trade flows in 2011

MAP 2: SCS daily LNG trade flows in 2011

MAP 3: SCS maritime claims

MAP 4: Spratly Island claims \& occupations

MAP 5: 9-dash map 15

FIGURE 1: Kilo-Class Submarine

FIGURE 2: Sovremenny-Class destroyer

FIGURE 3: Woody Island

FIGURE 4: Osumi-Class LST

FIGURE 5: Hyuga-Class Helicopter Destroyer

FIGURE 6: Izumo-Class Helicopter Destroyer

FIGURE 7: Thitu Island

FIGURE 8: Spratly Island proper 


\section{i. Introduction:}

\section{Background}

East and Southeast Asia are projected to be the most economically dynamic regions in the world for the coming years. With an average GDP growth of $7.1 \%$ in 2013, the area is expected to "contribute $40 \%$ of global growth and one-third of global trade this year; higher than any other region in the world."1 However, despite its economic vitality, East and Southeast Asia continue to be plagued by ongoing territorial disputes among a number of states. These disputes do not appear to be headed towards peaceful resolution and could potentially derail the economic aspirations of many countries in the region as well as abroad. The most critical of the ongoing rows in East and Southeast Asia is the South China Sea (SCS) territorial disputes. This is the result of a number of factors: particularly the SCS's global position as maritime superhighway, its significant energy deposits, and its abundant marine resources. The territorial disputes have the potential to disrupt global trade and potentially destabilize the region.

\section{Maritime Superhighway}

Stretching from the Strait of Malacca in the southwest to the Luzon Straits in the northeast, the SCS serves as one of the main arteries for global shipping. Over " $50 \%$ of the world's merchant fleet tonnage crosses through the Malacca, Sunda and Lombok Straits, with the majority continuing on into the South China Sea."2 The tanker traffic that passes through the Malacca Straits "is more than three times greater than the Suez Canal

\footnotetext{
1 “East Asia Pacific Economic Update, October 2013 - Rebuilding Policy Buffers and Reinvigorating Growth,” The World Bank, 2013, http://www.worldbank.org/en/region/eap/publication/east-asiapacific-economic-update-october-2013 (Accessed November 15, 2013)

${ }^{2}$ Emmers, Ralf, Geopolitics and Maritime Territorial Disputes in East Asia
} (New York: Routledge, 2010), Pg. 65 
traffic, and well over five times more than the traffic of the Panama Canal.”3 The Energy Information Administration (EIA), an agency of the U.S. Department of Energy, estimated that by the end of 2011 oil trade passing through the Malacca Straits was greater than 15 million barrels per day (BPD), amounting to one-third of all seaborne oil and second only to the Strait of Hormuz (See Map 1). ${ }^{4}$ The EIA also reported that "about 6 trillion cubic feet (Tcf) of liquefied natural gas, or more than half of global LNG trade, passed through the South China Sea in 2011. Half of this amount continued on to Japan, with the rest of it going to South Korea, China, Taiwan, and other regional countries (See Map 2)."5 Lastly, significant quantities of coal from Australia and Indonesia, which are the world's two largest coal exporters, are transported through the SCS to markets around the world, particularly China and Japan. ${ }^{6}$

The sea lanes of communications (SLOC) of most countries in the region traverse through the SCS, making it a lifeline to the economic security of these countries. As a result, the potential for conflict over territorial disputes in the SCS is of vital importance for countries which rely heavily on energy imports and whose economies are primarily driven by exports of manufactured goods. This is particularly the case with Japan which relies on its SCS SLOC for $80 \%$ of its oil supply and $70 \%$ of its exports. Therefore, "any

\footnotetext{
${ }^{3}$ Khemakorn, Pakjuta, "Sustainable Management of Pelagic Fisheries in the South China Sea Region," United Nations - The Nippon Foundation, 2006, Pg. 14, http://www.un.org/depts/los/nippon/unnff_programme_home/fellows_pages/fellows_papers/khem akorn_0607_thailand.pdf (Accessed November 12, 2013)

4 "The South China Sea is an Important World Energy Trade Route," Energy Information Administration, 2013, http://www.eia.gov/todayinenergy/detail.cfm?id=10671 (Accessed December 20, 2013)

${ }^{5}$ Ibid.

${ }^{6}$ Ibid.
} 
disruption of the maritime traffic due to frictions between claimant states or undue control by a single dominant power would have a catastrophic impact on Japan. For this reason, the SCS is seen as a "national security concern” by diplomatic authorities."7

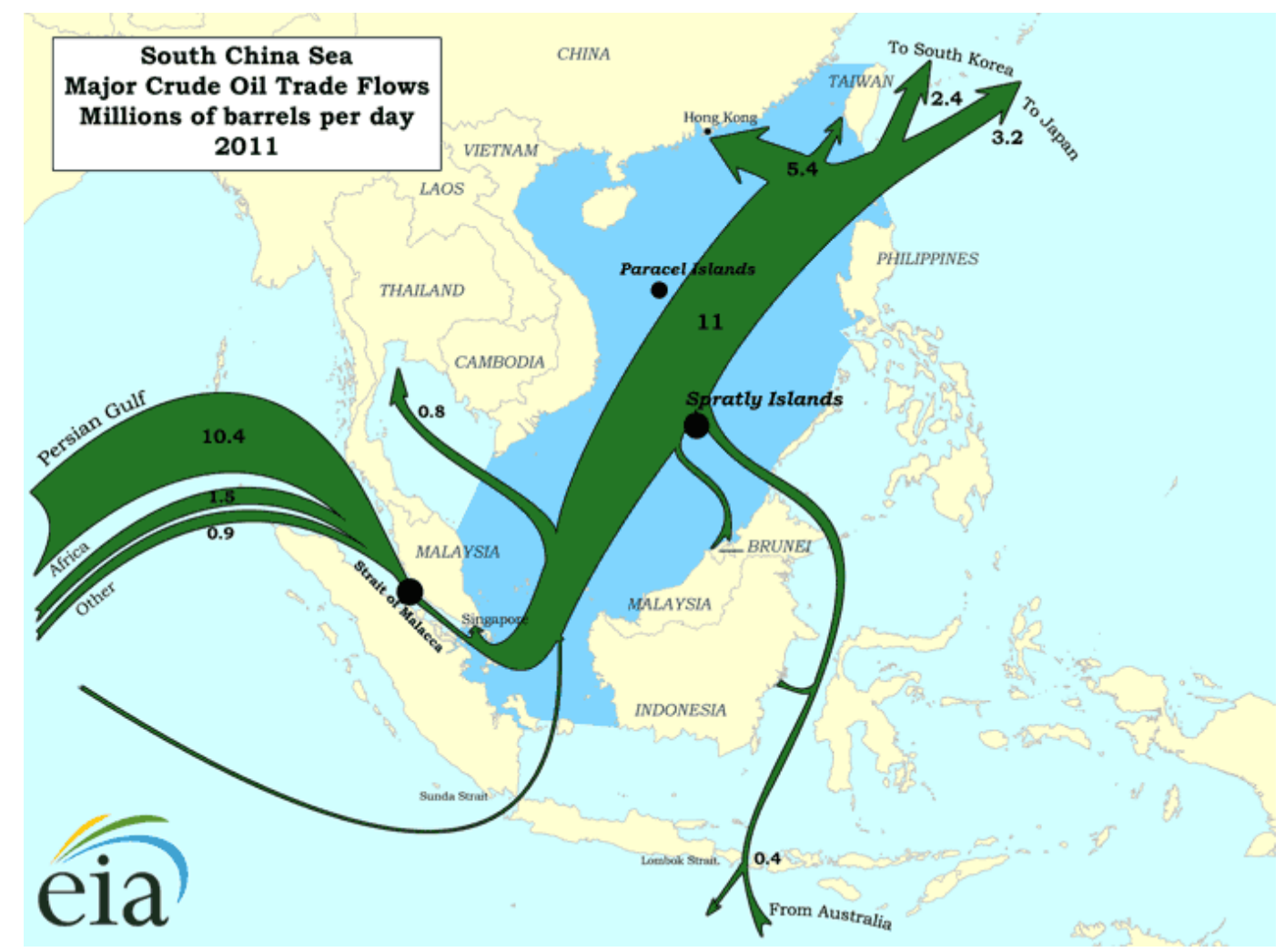

Map 1. SCS daily oil trade flows in 2011.

Source EIA: http://www.eia.gov/countries/regions-topics.cfm?fips=scs

\footnotetext{
${ }^{7}$ Pajon, Celine, “Japan and the South China Sea: Forging Strategic Partnerships in a Divided Region,” Institut Francais des Relations Internationales, Center for Asian Studies, 2013, Pg. 7, http://www.ifri.org/?page=contribution-detail\&id=7555 (Accessed September 20, 2013)
} 


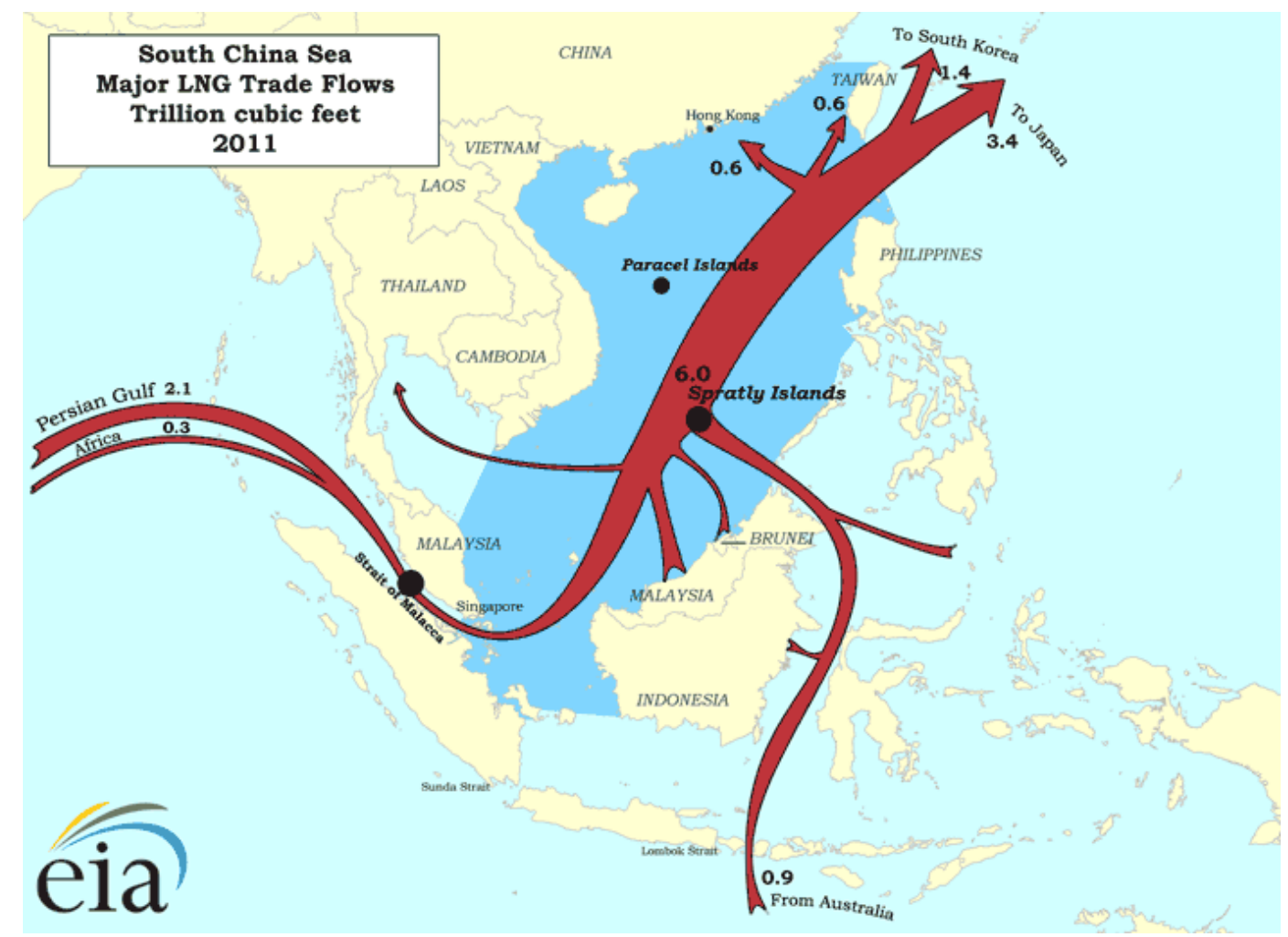

Map 2. SCS daily LNG trade flows in 2011.

Source EIA: http://www.eia.gov/countries/regions-topics.cfm?fips=scs

\section{Energy Deposits}

The second factor that makes the SCS increasingly important is its estimated energy deposits. The robust economic growth in the region is expected to increase the demand for fossil fuels. The EIA projects that Asian countries outside of the Organization for Economic Cooperation Development (OECD) will have a 2.6\% annual increase in demand for liquid fuels. This will result in an increased share of global consumption from $20 \%$ in 2008 to $30 \%$ by $2035 .{ }^{8}$ Non-OECD Asian countries' natural gas consumption is also expected to grow at an annual rate of $3.9 \%$; increasing their share of global

\footnotetext{
8 “South China Sea," Energy Information Administration, 2013, http://www.eia.gov/countries/regions-topics.cfm?fips=scs (Accessed December 20, 2013)
} 
consumption from $10 \%$ in 2008 to $19 \%$ by 2035 . The "EIA expects China to account for 43 percent of that growth." "With Southeast Asian domestic oil production projected to remain flat or decline as consumption rises, the region's countries will look to new sources of energy to meet domestic demand.” ${ }^{10}$ As a result, these countries are increasingly looking to the SCS as a potential source of energy to meet national demands in order to continue promoting economic growth. This has created an imperative for securing parts of the SCS as a way to acquire new sources of fossil fuel. However, the territorial disputes in the region have hindered efforts to conduct proper exploration of energy resources in the area.

There are a number of conflicting claims regarding the oil and natural gas deposits in the SCS. The Chinese have been the most enthusiastic in their estimates. “Zhang Dawei, an official at China’s Ministry of Land Resources, has optimistically claimed that the South China Sea might hold 23-40 billion tons of oil reserves." ${ }^{\text {11 }}$ That figure is larger than China's current onshore resources. The Chinese have also estimated that the area may contain more than 2,000 tcf of natural gas reserves. ${ }^{12} \mathrm{~A}$ different study conducted by the state-owned Chinese National Offshore Oil Company (CNOOC) estimates that the SCS holds around 125 billion barrels of oil and 500 tcf of natural gas. However, no independent studies have been able to confirm any of the optimistic

\footnotetext{
${ }^{9}$ Ibid.

${ }^{10}$ Ibid.

${ }^{11}$ Emmers, Ralf, Geopolitics and Maritime Territorial Disputes in East Asia (New York: Routledge, 2010), Pg. 77

${ }^{12}$ Ibid.
} 
estimates provided by Chinese agencies or corporations. ${ }^{13}$ A 1995 study conducted by Russia’s Research Institute of Geology of Foreign Countries concluded that deposits were closer to 6 billion barrels of oil in the Spratly Islands, of which $70 \%$ would be natural gas. ${ }^{14}$

Two American agencies have also conducted surveys of the area, providing yet another set of conflicting figures. The EIA estimates that the oil and natural gas reserves in the SCS are 11 billion barrels and 190 tcf respectively. The report indicates that these figures represent proven and probable reserves and are much closer to the high-end estimate. ${ }^{15}$ In the next survey:

"The U.S. Geological Survey (USGS) analyzed the potential for undiscovered conventional oil and gas fields within several geologic provinces of Southeast Asia in 2010 as part of its World Petroleum Resources Assessment Project. The study included a significant area of the South China Sea, which the USGS estimates may contain anywhere between 5 and 22 billion barrels of oil and between 70 and 290 trillion cubic feet of gas in as-yet undiscovered resources (not including the Gulf of Thailand and other areas adjacent to the South China Sea). These additional resources are not considered commercial reserves at this time because it is unclear how economically feasible it would be to extract them."16

Despite the conflicting claims, however, the fact is that the SCS does possess valuable energy resources which are desperately needed in the region in order to promote continued economic growth. Chinese media in particular have referred to the area as the "Second Persian Gulf."17

\footnotetext{
13 “South China Sea,” Energy Information Administration, 2013, http://www.eia.gov/countries/regions-topics.cfm?fips=scs (Accessed December 20, 2013)

${ }^{14}$ Banlaoi, Rommel C., Philippines-China Security Relations: Current Issues and Emerging Concerns (Quezon City: Philippine Institute for Peace, Violence and Terrorism Research, 2012), Pg. 25

15 “South China Sea,” Energy Information Administration, 2013, http://www.eia.gov/countries/regions-topics.cfm?fips=scs (Accessed December 20, 2013)

${ }^{16}$ Ibid.

${ }^{17}$ Banlaoi, Rommel C., Philippines-China Security Relations: Current Issues and Emerging Concerns
} 


\section{Marine Resources}

The third major factor that makes the SCS important is its abundant marine resources. This is underscored by the fact that by 1995 the SCS contributed to $12 \%$ of the total marine global production as well as $54 \%$ of marine culture production. ${ }^{18}$ The fishing industry is one of the most important sectors to the economy and livelihood of the many states in the SCS region. During the 3-year span of 2000-2003 the per capita consumption of fish in the region was $26.1 \mathrm{~kg}$ a year. Compared to the world average of $16.3 \mathrm{~kg}$ a year, it is clear that the states in the SCS area rely heavily on fish and other marine foods for nutrition and protein. ${ }^{19}$ As a matter of fact "fish protein is more than 22 percent of the average Asian diet, significantly higher than the global average of 16 percent." ${ }^{20}$ The fishing industry is a multi-billion dollar a year business that is a major provider of employment and income for millions of people in the region.

"In 1994, the estimated numbers of full and part-time fishers engaged in marine and inland fisheries were 8.7 million and 1.7 million, respectively. According to FAO's findings, around $85 \%$ of the world's fishers are concentrated in Asia, particularly in the SCS region, compared to $77 \%$ in 1970 . China has the largest number of fishers followed by Vietnam, Indonesia and the Philippines. In total, at least 31 million people are

(Quezon City: Philippine Institute for Peace, Violence and Terrorism Research, 2012), Pg. 25

${ }^{18}$ Gomez, Edgardo D., "Is the Degradation of Resources in the South China Sea Reversible?: Approaches to Sustainable Management,” International Symposium of Protection and Management of the Coastal Marine Ecosystem, 2000, Pg. 219, http://www.emecs.or.jp/2000thai-sympo/pdf/re-gomes.pdf (Accessed December 20, 2013)

${ }^{19}$ Khemakorn, Pakjuta, "Sustainable Management of Pelagic Fisheries in the South China Sea Region," United Nations - The Nippon Foundation, 2006, Pg. 29, http://www.un.org/depts/los/nippon/unnff_programme_home/fellows_pages/fellows_papers/khem akorn_0607_thailand.pdf (Accessed November 12, 2013)

${ }^{20}$ Cronin, Patrick M., China's Global Quest for Resources and Implication for the United States,” Center for a New American Security, 2012, http://www.cnas.org/files/documents/publications/CNAS\%20Testimony\%20Cronin\%20012612_1 .pdf (Accessed December 20, 2013) 
engaged in the fisheries sector (including aquaculture) and related industries in the region." 21

The biodiversity of the SCS makes it a prime location for marine resource extraction. "According to a Chinese study, species abundance in the SCS region includes: 1,027 fish, 91 shrimp and 73 cephalopod species in the Northern continental shelf; approximately 205 fish and 96 shrimp species in the continental slope, and more than 520 fish species around the islands and reefs of the Southern waters.”22 However, intense overfishing and pollution are causing concerns over the long-term productivity of the area. $^{23}$ This appears to be a particular concern in the coastal areas of the SCS states, and as a result, most have ventured beyond their territorial waters and deeper into the contested areas of the SCS. Consequently, fishing has become a politically sensitive issue for the disputing countries. Numerous encounters have resulted in the apprehension of fishing crews. Many have been fined, harassed, and even killed. ${ }^{24}$

\section{The South China Sea Disputes}

As previously stated, the vital resources and strategic location of the SCS make the ongoing territorial disputes the most important security problem in the East and Southeast Asia region. It is a dispute that can destabilize the economies of the states in the SCS area and can threaten the interests of regional and global powers like Japan, and

${ }^{21}$ Khemakorn, Pakjuta, "Sustainable Management of Pelagic Fisheries in the South China Sea Region," United Nations - The Nippon Foundation, 2006, Pg. 29, http://www.un.org/depts/los/nippon/unnff_programme_home/fellows_pages/fellows_papers/khem akorn_0607_thailand.pdf (Accessed November 12, 2013)

${ }^{22}$ Ibid. Pg. 18-19

${ }^{23}$ Emmers, Ralf, Geopolitics and Maritime Territorial Disputes in East Asia (New York: Routledge, 2010), Pg. 77

${ }^{24}$ Storey, Ian, “The South China Sea Dispute (Part 1): Negative Trends Continue in 2013,” The Jamestown Foundation China Brief 13:12 (2013), Pg. 3-6, http://www.jamestown.org/uploads/media/cb_06_09.pdf (Accessed, December 5, 2013) 
the United States. While these states do not have direct territorial claims on the SCS, they depend on the freedom of navigation in the area in order to conduct trade, research, and surveillance operations. In essence, these states have a vested interest in keeping their SLOC in the SCS open. Armed conflict among the disputing parties could potentially threaten this national interest. These powers are also concerned that sole Chinese control of all SCS features could mean a disruption of their SLOC.

The parties to the current disputes include: China, Taiwan, Vietnam, Philippines, Malaysia and Brunei. All of them are signatories to the United Nations Convention on the Law of the Sea (UNCLOS). The current statuses of the claims are as follows:

- "A dispute over the Paracel Islands in the SCS, which are claimed by China and Vietnam, and occupied by China;

- A dispute over the Spratly Islands in the SCS, which are claimed entirely by China, Taiwan, and Vietnam, and in part by the Philippines, Malaysia, and Brunei, and which are occupied in part by all these countries except Brunei; and

- A dispute over Scarborough Shoal in the SCS, which is claimed by China, Taiwan, and the Philippines."25 (See Maps 3\&4)

For the purposes of the present paper the only claims which will be evaluated are those of the People's Republic of China (PRC), the Philippines, and Vietnam. The reason for narrowing the list of claimants is a result of their relevance to the overall research topic which will be discussed below. In the Spratly archipelago China occupies 7 features, Vietnam 21, and the Philippines $9 .^{26}$ There is a $10^{\text {th }}$ Philippine area that appears to be absent from most available listings of SCS features currently under control by a sovereign state. This feature is internationally known as the Second Thomas Shoal, a

\footnotetext{
${ }^{25}$ O’Rourke, Ronald, “Maritime Territorial and Exclusive Economic Zone (EEZ) Disputes Involving China: Issues for Congress," Congressional Research Service, 2013, Pg. 1, http://www.fas.org/sgp/crs/row/R42784.pdf (Accessed September 12, 2013)

${ }^{26}$ Clive Schofield and Ian Storey, “The South China Sea Disputes: Increasing Stakes and Rising Tensions,” The Jamestown Foundation, 2009, Pg. 10
} 
small shoal in which the Philippines maintains a minor force composed of 10 marines. They are housed in a World War II-era landing transport ship which was intentionally run aground in 1999 in order to establish a permanent presence in the area. ${ }^{27}$

${ }^{27}$ Bonnie Glaser and Alison Szalwinski, "Second Thomas Shoal Likely the Next Flashpoint in South China Sea,” The Jamestown Foundation China Brief 13:13 (2013), Pg. 5-6, http://www.jamestown.org/uploads/media/cb_06_21.pdf (Accessed December 5, 2013) 


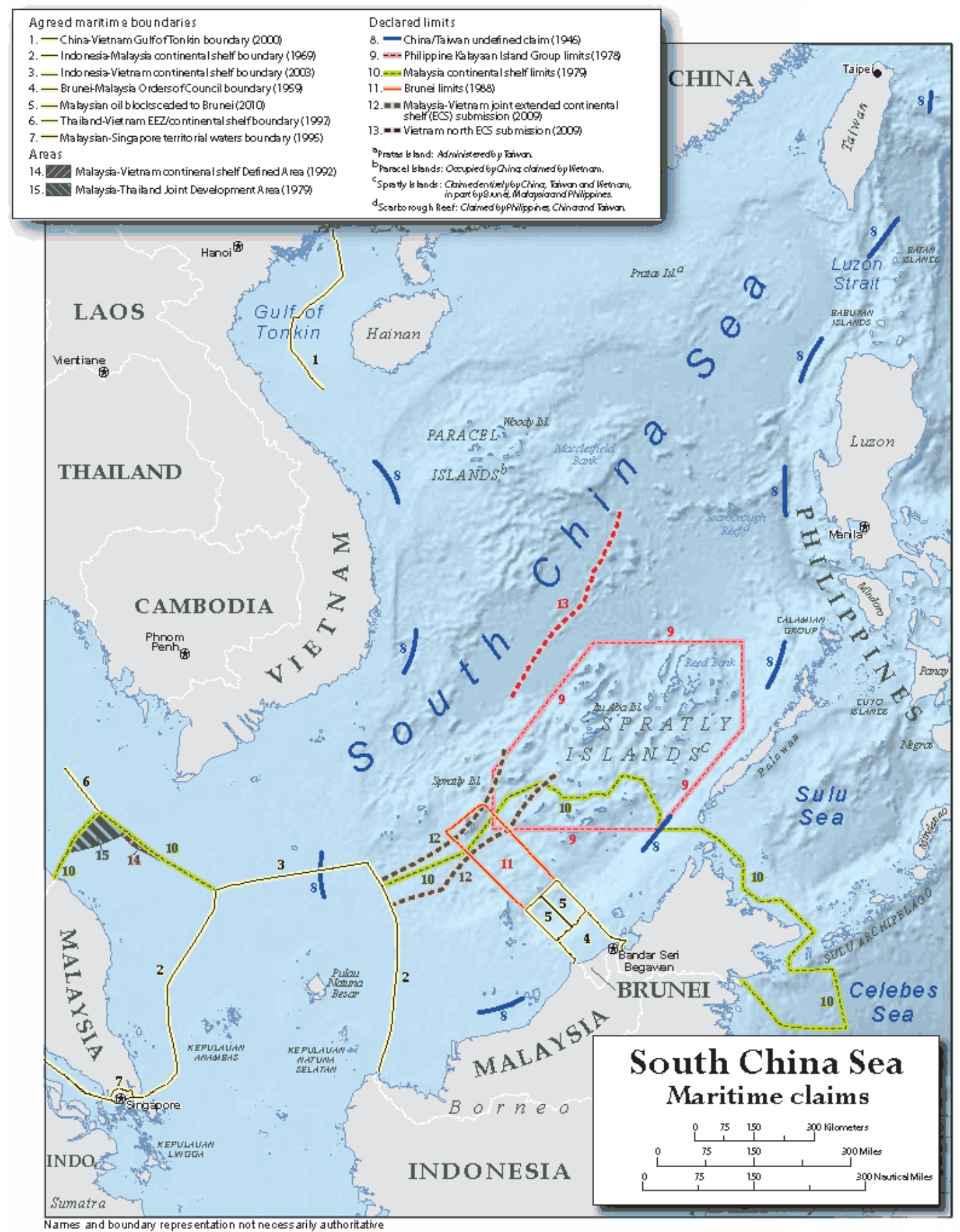

Map 3. SCS maritime claims.

Source EIA: http://www.eia.gov/countries/regions-topics.cfm?fips=scs 


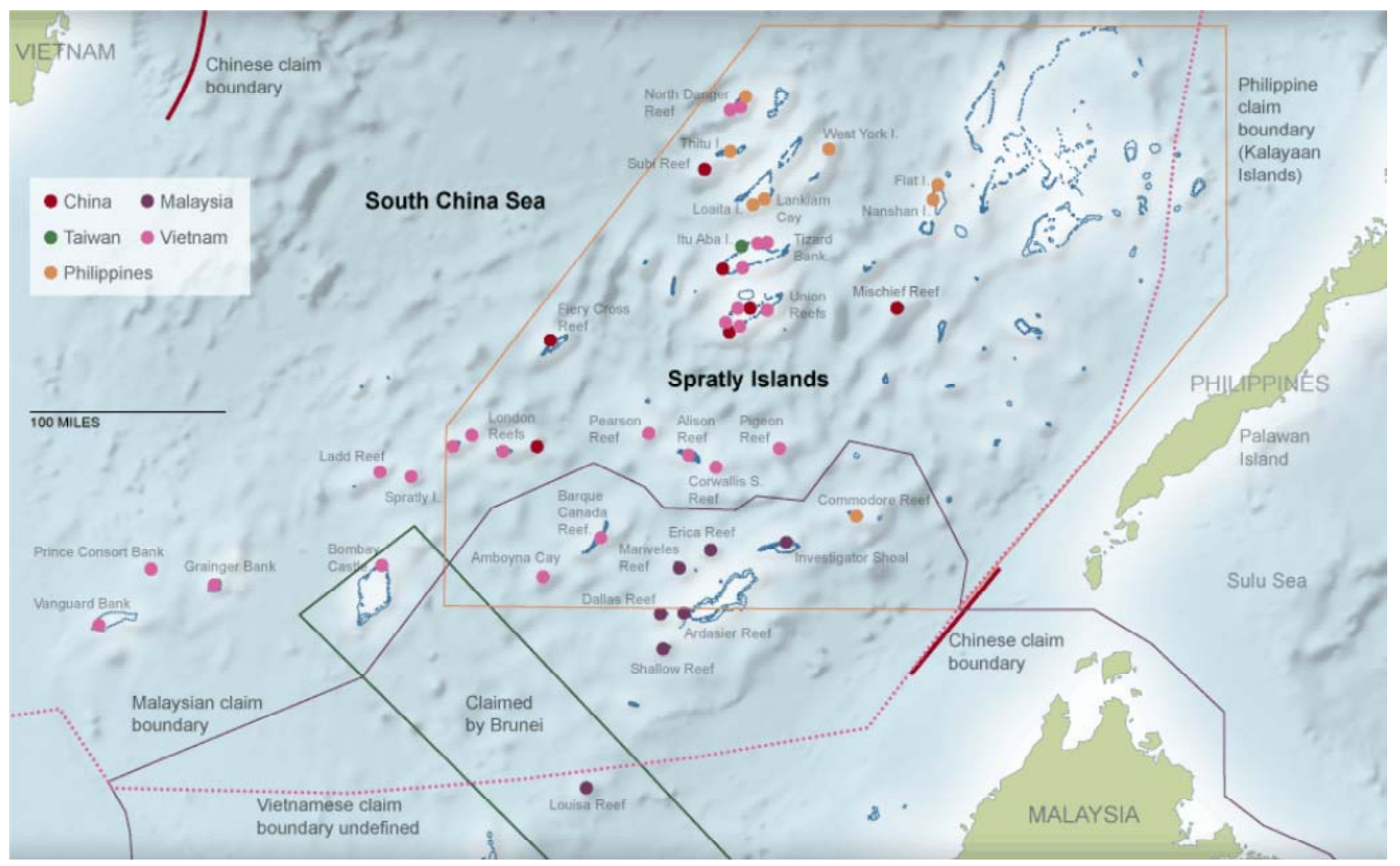

Map 4: Spratly Island claims \& occupations. Source The NYT and the State Department: http://www.nytimes.com/interactive/2012/05/31/world/asia/Territorial-Claims-in-South-ChinaSea.html?_r=3\&

\section{$\underline{\text { China }}$}

Chinese claims on the SCS are largely based on historical and archeological grounds. They cite the numerous expeditions sent to the area during the Han Dynasty in 110 CE and by the Ming Dynasty in the $15^{\text {th }}$ century. ${ }^{28}$ Furthermore, historical references, maps, and artifacts have been used to supplement their territorial claims. ${ }^{29}$ After World War II (WWII) ended, Japan, which had been occupying many of the features in the Paracel and Spratly Islands for many years, withdrew its forces and abandoned all claims

${ }^{28}$ Burgess, J. Peter, "The Politics of the South China Sea: Territoriality and International Law,” Security Dialogue 34:1 (2003), Pg. 8, http://community.middlebury.edu/ scs/docs/Burgess,\%20Politics\%20of\%20the\%20South\%20Chi na\%20Sea-Territoriality\%20and\%20.pdf (Accessed December 5, 2013)

${ }^{29}$ Emmers, Ralf, Geopolitics and Maritime Territorial Disputes in East Asia (New York: Routledge, 2010), Pg. 67 
in the region. This paved the way for the Republic of China under Chiang Kai-Shek to define Chinese traditional claims in the area by drawing up the now-famous nine-dash map. The U-shaped line map was adopted by the Chinese Communist Party (CCP) after their victory over the Nationalist forces of Chiang Kai-Shek. Although the original map consisted of 11 dashes, Premier Zhou Enlai approved the removal of two of the lines around the Gulf of Tonkin in 1953. Subsequent maps published by the PRC have shown 9 rather than 11 lines. ${ }^{30}$ The San Francisco Treaty of 1951 finalized the terms of Japanese surrender and as a response the CCP formalized its claims in the SCS by referring to the Nationalist map (See Map 5). ${ }^{31}$

This map represents the most expansive claim among the parties to the disputes because of the fact that the U-shaped line that it forms covers roughly $80 \%$ of the total area of the SCS. ${ }^{32}$ The area far exceeds what is claimable as territorial waters under United Nations Convention on the Law of the Sea. This is a problem exacerbated by the fact that the claimed area includes waters that lie well within the claimable Exclusive Economic Zones (EEZ) of the Philippines, Malaysia, Brunei, and Vietnam. ${ }^{33}$ For its part China has been ambiguous over what the nine-dash line in the map actually represents. It is unclear whether the Chinese are claiming sovereignty over the entire sea and seabed in

\footnotetext{
${ }^{30}$ Li Jinming and Li Dexia, “The Dotted Line on the Chinese Map of the South China Sea: A Note,” Ocean Development \& International Law 34 (2003), Pg. 290, http://community.middlebury.edu/ scs/docs/Li\%20and\%20LiThe\%20Dotted\%20Line\%20on\%20the\%20Map.pdf (Accessed September 11, 2013)

${ }^{31}$ Emmers, Ralf, Geopolitics and Maritime Territorial Disputes in East Asia (New York: Routledge, 2010), Pg. 67

${ }^{32}$ O’Rourke, Ronald, “Maritime Territorial and Exclusive Economic Zone (EEZ) Disputes Involving China: Issues for Congress," Congressional Research Service, 2013, Pg. 9, http://www.fas.org/sgp/crs/row/R42784.pdf (Accessed September 12, 2013)

${ }^{33}$ Ibid. Pg. 11
} 
the enclosed area, or if it is making more limited claims, such as sovereignty over the land features or to historical fishing and navigational rights. ${ }^{34}$

Despite some ambiguity over the exact claims being made by the Chinese government with the nine-dash line, it does appear that at minimum China is claiming sovereignty over the island groups within the area enclosed by U-shaped line on the map. The island groups claimed are the Pratas Islands (Dongsha), the Paracel Islands (Xisha), Macclesfield Bank (Zhongsha), and the Spratly Islands (Nansha). ${ }^{35}$ China’s 1992 Law on the Territorial Sea and Contiguous Zone placed these island groups under the administration of Hainan Island Province. ${ }^{36}$ This claim was further reinforced in 2009 when China submitted the nine-dash map to the United Nations with an accompanying statement that read:

"China has indisputable sovereignty over the islands in the South China Sea and the adjacent waters, and enjoys sovereign rights and jurisdiction over the relevant waters as well as the seabed and subsoil thereof (see attached map [of the nine-dash line]). The above position is consistently held by the Chinese Government, and is widely known by the international community., ${ }^{37}$

${ }^{34}$ Ben Dolven and others, eds., "Maritime Territorial Disputes in East Asia: Issues for Congress," Congressional Research Service, 2013, Pg. 8, http://www.fas.org/sgp/crs/row/R42930.pdf (Accessed September 12, 2013)

${ }^{35}$ Dutton, Peter, “Three Disputes and Three Objectives, China and the South China Sea," Naval War College Review 2011, Pg. 45

${ }^{36}$ Khemakorn, Pakjuta, "Sustainable Management of Pelagic Fisheries in the South China Sea Region,” United Nations - The Nippon Foundation, 2006, Pg. 24, http://www.un.org/depts/los/nippon/unnff_programme_home/fellows_pages/fellows_papers/khem akorn_0607_thailand.pdf (Accessed November 12, 2013)

${ }^{37}$ O’Rourke, Ronald, “Maritime Territorial and Exclusive Economic Zone (EEZ) Disputes Involving China: Issues for Congress," Congressional Research Service, 2013, Pg. 12, http://www.fas.org/sgp/crs/row/R42784.pdf (Accessed September 12, 2013) 
The Chinese statement was made in response to a joint submission made by Malaysia and Vietnam regarding their territorial claims to the United Nations. ${ }^{38}$ By June 2012 the Chinese government had announced that it would be upgrading the administrative level of Sansha city, a city that is located on an island in the Paracel Island group. The following month the PRC stated that a military garrison would be set up on the island. Sansha city is used to administer the disputed areas in the SCS. ${ }^{39}$

\footnotetext{
${ }^{38}$ Ben Dolven and others, eds., "Maritime Territorial Disputes in East Asia: Issues for Congress,” Congressional Research Service, 2013, Pg. 8-9, http://www.fas.org/sgp/crs/row/R42930.pdf (Accessed September 12, 2013)

${ }^{39}$ Ibid. Pg. 9
} 


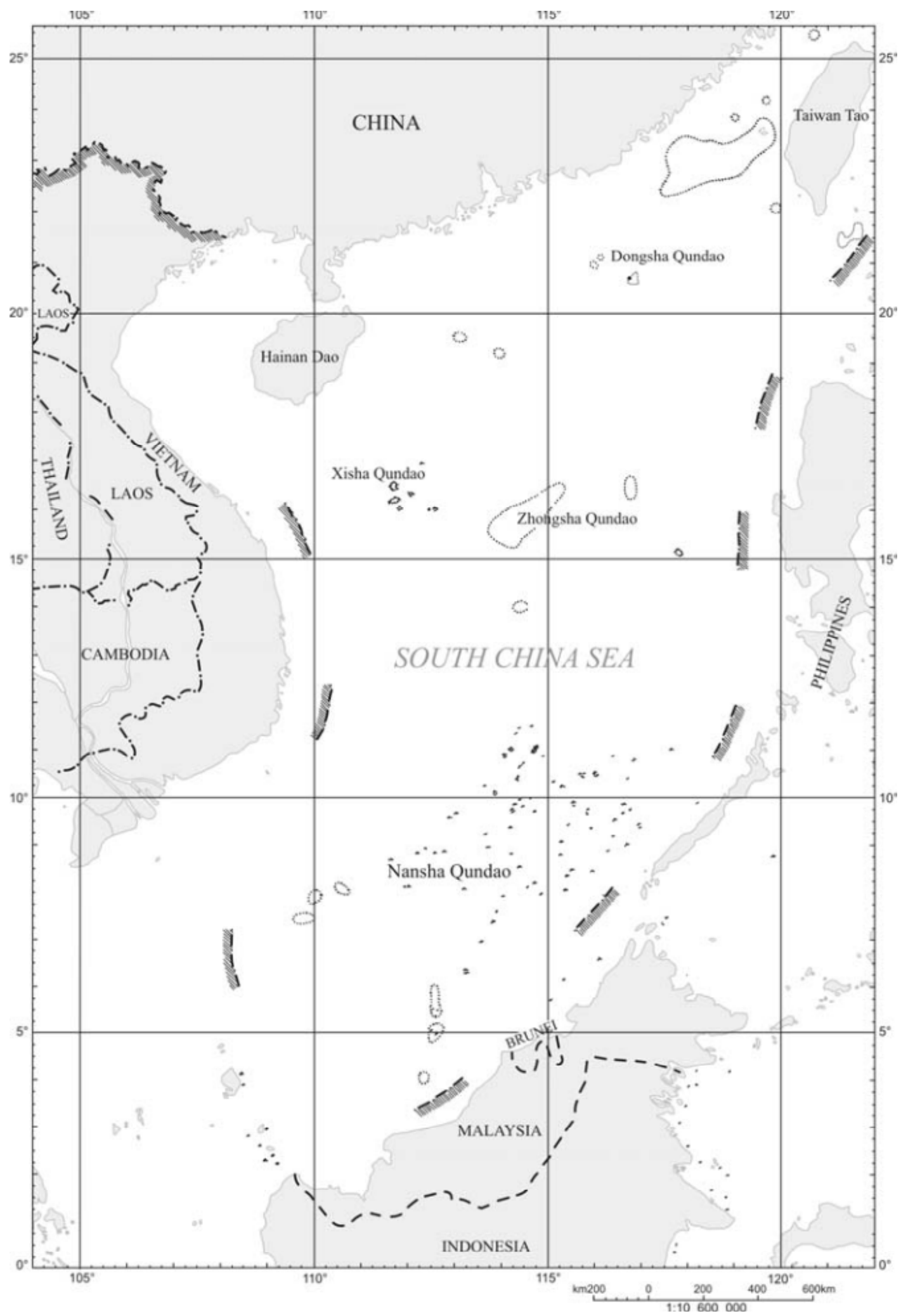

Map 5. 9-dash map. Source United Nations :http://www.un.org/Depts/los/clcs_new/submissions_files/submission_vnm_37_2009.htm 


\section{The Philippines}

The Republic of the Philippines' claims in the SCS are also based on historical justifications as well as the principle of terra nullius, which essentially means that the islands were not occupied or under the sovereign authority of any other state. The Philippines began laying claims in the SCS as early as 1947. At the time the Spratly Islands were referred as the "New Southern Islands" by the Philippine government. The Philippine Foreign Affairs Secretary at the time, Carlos P. Garcia, requested the Allied Forces to place the islands under the jurisdiction of the Philippines, citing security reasons. ${ }^{40}$ In the same year a Filipino businessman and lawyer by the name of Tomas Cloma established settlements in the Spratlys and declared them a protectorate. He named the group of islands he identified or settled as the "Kalaya'an" or "Freedomland."41

By 1974 Cloma deeded the Kalaya'an group to the Philippine government and in both 1971 and 1978 the Philippine President Ferdinand Marcos declared the Kalaya'an Island Group (KIG) to be formally part of the Philippines. ${ }^{42}$ The 1978 declaration was made official through Presidential Decree No. 1596 in which the KIG are identified as a municipality of Palawan. ${ }^{43}$ Since 1968 the Philippines has had a military presence in the KIG group and effectively controls and administers at least 8 of its features. The KIG

\footnotetext{
${ }^{40}$ Banlaoi, Rommel C., Philippines-China Security Relations: Current Issues and Emerging Concerns (Quezon City: Philippine Institute for Peace, Violence and Terrorism Research, 2012), Pg. 23

${ }^{41}$ Hong, Nong, UNCLOS and Ocean Dispute Settlement: Law and Politics in the South China Sea (New York: Routledge, 2012), Pg. 18

${ }^{42}$ Ibid.

${ }^{43}$ Banlaoi, Rommel C., Philippines-China Security Relations: Current Issues and Emerging Concerns (Quezon City: Philippine Institute for Peace, Violence and Terrorism Research, 2012), Pg. 24
} 
also hosts residents who participate in local elections, a fact that allows the Philippine government to demonstrate sovereignty in the area. ${ }^{44}$ It is the exploration and "discovery" of the KIG group by Tomas Cloma that serves as one of the historical bases of the Philippine claim.

The second historical bases for the Philippine claim comes from previous treaties it had signed with other parties in order to demarcate maritime boundaries. "The Philippines continues to claim that all of the waters between its baselines and the lines defined by a series of treaties dating from 1898, 1900, and 1930, the so-called “Philippines Treaty Limits” or "Philippines Box,” constitute its territorial waters.”45 These claims essentially extend the Philippines’ territorial sea from the 12 nautical miles allowed by the UNCLOS to 285 nautical miles. Although the disparity between the customary law of the UNCLOS and these treaties is clear, the Philippines has had difficulties abandoning the Treaty Limits claim as a result of domestic pressures as well as constitutional constraints. ${ }^{46}$

The Philippine justification for its terra nullius claim is centered on the Japanese withdrawal from the area after its defeat in WWII. Because Japan did not cede the islands to any other nation in the San Francisco Treaty, the islands were given the status of

\footnotetext{
${ }^{44}$ Ibid.

${ }^{45}$ Clive Schofield and Ian Storey, "The South China Sea Disputes: Increasing Stakes and Rising Tensions,” The Jamestown Foundation, 2009, Pg. 27

${ }^{46}$ Ibid. Pg. 27-28
} 
“trusts.” This essentially nullified any previous ownership of the islands. As a result, the Philippine government felt that its occupation of the islands was justified. ${ }^{47}$

In recent years the Philippine government has attempted to bring its SCS claims more in line with the UNCLOS because of the fact that its Treaty Limits claim was undermining its position as a claimant. ${ }^{48}$ In 2009 the Philippine Congress ratified the Archipelagic Baselines Act. In accordance with UNCLOS provisions the Philippine claimed 12 nautical miles of territorial sea and 200 nautical miles of EEZ from straight from territorial baselines. The Kalaya'an box that previously used to encapsulate the 53 features that it claimed has been done away with, although the Philippine continues to lay claim to those features under the "Regime of Islands" clause in the UNCLOS. At present only a small section of its southern boundary with Malaysia continues to be determined by the Treaty of Paris which is one of the treaties that make up the old Treaty Limits. ${ }^{49}$

\section{$\underline{\text { Vietnam }}$}

Like the other claimants, Vietnam bases some of its claims on historical usage. Court records from the reign of King Le Thanh Tong (1460-1497) indicate that Vietnam claimed sovereignty over the Spratly Islands. This historical claim is reinforced by Vietnamese maps dated to the $17^{\text {th }}$ century that incorporated the Spratlys into Vietnam. ${ }^{50}$

\footnotetext{
${ }^{47}$ Hong, Nong, UNCLOS and Ocean Dispute Settlement: Law and Politics in the South China Sea (New York: Routledge, 2012), Pg. 18

${ }^{48}$ Poling, Gregory B., The South China Sea in Focus: Clarifying the Limits of Maritime Dispute,” Center for Strategic \& International Studies, 2013, Pg. 10, http://csis.org/files/publication/130717_Poling_SouthChinaSea_Web.pdf (Accessed December 1, 2013)

${ }^{49}$ Ibid.

${ }^{50}$ Rowan, Joshua P., “The U.S.-Japan Security Alliance ASEAN and the South China Sea Dispute,” Asian Survey 45:3 (2005), Pg. 424
} 
Like China, Vietnam has also presented archeological evidence to bolster its claims to the Spratly and Paracel Islands. ${ }^{51}$ In addition to historical usage and archeological evidence, the Vietnamese government proclaims sovereignty over the Paracel and Spratly Island groups based on French colonial claims. When Vietnam became a protectorate of France in 1884 in the aftermath of the Sino-French War, France declared sovereignty over the entirety of the Paracel and Spratly archipelagos, an act which continues to be used to justify Vietnamese claims to this day. ${ }^{52}$

Like the Philippines, Vietnam has made some of its claims on the concept of terra/res nullius. The Vietnamese claim that before the French formally occupied some of the features in the Paracel and Spratly archipelagos in 1933, the islands were essentially unclaimed and therefore a "no man's land. ${ }^{, 53}$ As a result, Vietnam took over the sovereignty of the islands after Vietnam became independent. Since 1973 the Vietnamese have controlled up to 22 features in the Spratly Island group alone, making them the most significant holder of territory among the claimants. ${ }^{54}$ Although Vietnam also claims sovereignty over the Paracels, the PRC effectively evicted the Vietnamese from the archipelago in 1974 after an intense naval battle. ${ }^{55}$ Fortunes for the Vietnamese

\footnotetext{
${ }^{51}$ Khemakorn, Pakjuta, “Sustainable Management of Pelagic Fisheries in the South China Sea Region,” United Nations - The Nippon Foundation, 2006, Pg. 28, http://www.un.org/depts/los/nippon/unnff_programme_home/fellows_pages/fellows_papers/khem akorn_0607_thailand.pdf (Accessed November 12, 2013)

${ }^{52}$ Rowan, Joshua P., “The U.S.-Japan Security Alliance ASEAN and the South China Sea Dispute,” Asian Survey 45:3 (2005), Pg. 424-425

${ }^{53}$ Hong, Nong, UNCLOS and Ocean Dispute Settlement: Law and Politics in the South China Sea (New York: Routledge, 2012), Pg. 17

${ }^{54}$ Ibid.

${ }^{55}$ Phan, Nga, “Shift as Vietnam Marks South China Sea Battle,” BBC News Asia, 2014, http://www.bbc.co.uk/news/world-asia-25709833 (Accessed January, 2014)
} 
have fared much better in the Spratly archipelago. After establishing a significant foothold there in the 70s, in 2007 the Vietnamese government held local elections in the area in order for the inhabitants to select a representative to the National Assembly. ${ }^{56}$ The Spratlys, known as Hoang Sa in Vietnam, are currently administered as a district of the Khahn Hoa province. ${ }^{57}$

The division of Vietnam from the 1950s to the 1970s led to some confusion in regards to the claims being made in the SCS. North Vietnamese Premier Pham Van Dong stated that his government recognized the PRC claims in both the Paracel and Spratly Islands. In contrast, the South Vietnamese government located in Saigon held on to its claims on both groups. ${ }^{58}$ In fact it was the Saigon government that had been occupying the Paracels when the PRC dislodged its forces from the archipelago. The North did not acknowledge the casualties suffered by the South during this clash and instead supported its communist ally in the claims. ${ }^{59}$ However, when South and North Vietnam reunited in 1975, Vietnam reasserted its claims to both island groups that the South had previously contested. $^{60}$

\footnotetext{
${ }^{56}$ Clive Schofield and Ian Storey, "The South China Sea Disputes: Increasing Stakes and Rising Tensions,” The Jamestown Foundation, 2009, Pg. 30

${ }^{57}$ Khemakorn, Pakjuta, “Sustainable Management of Pelagic Fisheries in the South China Sea Region,” United Nations - The Nippon Foundation, 2006, Pg. 28, http://www.un.org/depts/los/nippon/unnff_programme_home/fellows_pages/fellows_papers/khem akorn_0607_thailand.pdf (Accessed November 12, 2013)

${ }^{58}$ Emmers, Ralf, Geopolitics and Maritime Territorial Disputes in East Asia (New York: Routledge, 2010), Pg. 68

${ }^{59}$ Phan, Nga, "Shift as Vietnam Marks South China Sea Battle,” BBC News Asia, 2014, http://www.bbc.co.uk/news/world-asia-25709833 (Accessed January, 2014)

${ }^{60}$ Emmers, Ralf, Geopolitics and Maritime Territorial Disputes in East Asia (New York: Routledge, 2010), Pg. 69
} 
In recent years, much in the same way as the Philippines, Vietnam has attempted to clarify its claims in the SCS in order to bring them into proper standing with the UNCLOS. In 2003 Vietnam signed a treaty with Indonesia that delimited the continental shelf and the EEZ boundaries between the two countries. That was followed by an agreement with China in 2004 that delimited the maritime boundaries in the Gulf of Tonkin. ${ }^{61}$ Then in 2009 Vietnam and Malaysia made a join submission to the United Nations Commission on the Limits of the Continental Shelf (CLCS). The submission dealt with claims beyond the 200 nautical mile EEZ. Lastly in 2012, Vietnam ratified a legislation called the Law of the Sea in which it claimed a 200 nautical mile EEZ and a 350 nautical mile continental shelf from its baselines. ${ }^{62}$ While there remain some discrepancies regarding certain portions of Vietnam's claims that do not fall in accordance with this new law, it is clear that it has made some efforts to bring its claims up to UNCLOS standards much the same manner as the Philippine has done.

\section{$\underline{\text { A Code of Conduct }}$}

After a decade of heightened tensions in the SCS leading to perceptions of a “China threat” among South East Asian countries, Beijing agreed to discuss a Code of Conduct (CoC) with the Association of Southeast Asian Nations (ASEAN). These discussions led to the Declaration of Conduct (DoC) in 2002. This became a key

\footnotetext{
${ }^{61}$ Poling, Gregory B., "The South China Sea in Focus: Clarifying the Limits of Maritime Dispute," Center for Strategic \& International Studies, 2013, Pg. 13, http://csis.org/files/publication/130717_Poling_SouthChinaSea_Web.pdf (Accessed December 1, 2013)

${ }^{62}$ Ibid.
} 
component of China's “charm offensive” in the region. ${ }^{63}$ The DoC outlines principles for avoiding conflicts in the SCS. It stated that:

"The Parties concerned undertake to resolve their territorial and jurisdictional disputes by peaceful means, without resorting to the threat or use of force, through friendly consultations and negotiations by sovereign states directly concerned, in accordance with universally recognized principles of international law, including the 1982 UN Convention on the Law of the Sea. ${ }^{, 64}$

Although the DoC called for the peaceful resolution of the disputes, it was non-binding, and therefore could not enforce any of its principles. The DoC was successful in easing tensions in the region for a number of years; however, by 2007 China had reverted to its assertive posture in the SCS. ${ }^{65}$ The return to heated rhetoric and clashes among the disputing parties has essentially stalled negotiations for a formal CoC in the SCS.

\section{ii. The Research:}

\section{Background}

This research will address questions concerning the relationships between the PRC, the Philippines, Vietnam, and Japan. Although Japan is not a claimant to any of the SCS features, it has been enhancing its economic and political presence in the area because of the fact that the SCS is the main artery of its SLOC. Since Japan also has an ongoing dispute with the PRC in the East China Sea (ECS) over the Senkaku/Diaoyu Islands, Tokyo is concerned that Beijing's attempt to change the status quo in the SCS could be a precursor to an escalation in the ECS. As a matter of fact, Japan has

\footnotetext{
${ }^{63}$ Clive Schofield and Ian Storey, "The South China Sea Disputes: Increasing Stakes and Rising Tensions,” The Jamestown Foundation, 2009, Pg. 19

${ }^{64}$ Ben Dolven and others, eds., "Maritime Territorial Disputes in East Asia: Issues for Congress," Congressional Research Service, 2013, Pg. 26, http://www.fas.org/sgp/crs/row/R42930.pdf (Accessed September 12, 2013)

${ }^{65}$ Clive Schofield and Ian Storey, "The South China Sea Disputes: Increasing Stakes and Rising Tensions,” The Jamestown Foundation, 2009, Pg. 19-20
} 
considered the disputes in the SCS and ECS as interrelated since 1992 when China passed its "Law on Territorial Waters and Contiguous Areas," in which it claimed sovereignty over the Spratly and the Senkaku/Diaoyu Islands. ${ }^{66}$

China's emergence as a more powerful and assertive actor has been one of the key factors in the rising tensions in the SCS and ECS. Its growing military capabilities have been instrumental in allowing it to undertake a more active and assertive role in its maritime periphery, something which has concerned nearly all of the countries in the region. ${ }^{67}$ As a reaction to China's growing assertiveness many of the countries in the area have undertaken military modernization programs of their own in order to provide a minimum credible defense along their coasts and their contested territories with China, resulting in what may be perceived as an arms race. This perception is reinforced by the fact that by 2010 defense spending among Southeast Asian countries was 60\% higher than it was in $2001 .^{68}$

Additionally, Southeast Asian countries have been pursuing a number of measures in order to protect themselves and their claims from further Chinese encroachment. The most immediate measure has been to socialize China within multilateral organizations, particularly ASEAN. The reasoning for this has been to find strength in numbers since four out of the ten ASEAN members have disputes in the SCS

\footnotetext{
${ }^{66}$ Pajon, Celine, “Japan and the South China Sea: Forging Strategic Partnerships in a Divided Region,” Institut Francais des Relations Internationales, Center for Asian Studies, 2013, Pg. 8, http://www.ifri.org/?page=contribution-detail\&id=7555 (Accessed September 20, 2013)

${ }^{67}$ Ben Dolven and others, eds., "Maritime Territorial Disputes in East Asia: Issues for Congress," Congressional Research Service, 2013, Pg. 23, http://www.fas.org/sgp/crs/row/R42930.pdf (Accessed September 12, 2013)

${ }^{68}$ Shearer, Andrew, "Southeast Asia and Australia: Case Studies in Responding to China’s Military Power," in Strategic Asia 2012-13: China's Military Challenge (Washington D.C.: The National Bureau of Asian Research, 2012), Pg. 251-253
} 
with China ${ }^{69}$ The second measure has been to pursue a strategy of hedging by inviting global and regional powers to play a larger role in the security of the region. ${ }^{70}$ Increasingly these countries have turned to Japan, an American ally, as another potential hedge vis-à-vis China. For its part Japan "is willing to play a role in the "great game" of influence currently underway in Southeast Asia, in which Tokyo is soft-balancing China and is supporting a more sustainable US military presence.,71

\section{Thesis Questions}

Having provided the background information to the current territorial disputes in the SCS and the rationale for its significance, we turn to the research questions that will inform the remainder of the paper. The present study will attempt to answer the following questions:

1. How does China's Military Modernization affect Japanese Normalization?

2. How does China's Military Modernization affect the SCS disputes?

3. How does Japan's Normalization affect the SCS disputes?

\section{Hypotheses}

1. China's military capabilities have significantly increased in recent decades as a result of its modernization programs. Increased military capabilities have enabled it to become more assertive in its territorial disputes with other countries in the region. Few other countries in the area have been more concerned about these developments than

\footnotetext{
${ }^{69}$ Ben Dolven and others, eds., "Maritime Territorial Disputes in East Asia: Issues for Congress," Congressional Research Service, 2013, Pg. 26, http://www.fas.org/sgp/crs/row/R42930.pdf (Accessed September 12, 2013)

${ }^{70}$ Medeiros, Evan S., “Strategic Hedging and the Future of Asia-Pacific Stability,” The Washington Quarterly 29:1 (2005), Pg. 145

${ }^{71}$ Pajon, Celine, “Japan and the South China Sea: Forging Strategic Partnerships in a Divided Region,” Institut Francais des Relations Internationales, Center for Asian Studies, 2013, Pg. 5, http://www.ifri.org/?page=contribution-detail\&id=7555 (Accessed September 20, 2013)
} 
Japan. Japan finds China's lack of military transparency and intensification of maritime activities as a serious security concern. ${ }^{72}$ Therefore, while Japan’s normalization process predates Chinese military advancements, it has served as a stimulus to hasten reforms. Anxiety over the Chinese military developments in the SCS prompted the Japanese to devote a section of their defense white paper to the area in 2012, citing growing concerns over the freedom of navigation in the region. ${ }^{73}$

2. After a period of relative cooperation in the early years of the 2000s, China resumed its hardline stance in the SCS. ${ }^{74}$ There have been a number of clashes in the SCS in recent years that has resulted in the intensification of the disputes. ${ }^{75}$ This has led to the increase of the military budgets for most countries in the region over the past decade as they seek to bolster their defensive capabilities. Although the littoral countries in the SCS are aware that China's military capabilities far exceed their own, they are determined to maintain at least a minimum credible defense capability. Japan appears to be willing to provide some assistance in this regard, particularly in the provision of coast guard vessels and training. ${ }^{76}$

\footnotetext{
72 “Defense Posture Review Interim Report,” Ministry of Defense, 2013, Pg. 2, http://www.mod.go.jp/j/approach/agenda/guideline/2013_chukan/gaiyou_e.pdf (Accessed October 13, 2013)

${ }^{73}$ Storey, Ian, "Japan's Growing Angst over the South China Sea," Institute of Southeast Asian Studies SEAS Perspective 20 (2013), Pg. 4, http://www.iseas.edu.sg/documents/publication/ISEAS_Perspective\%202013_20.pdf ${ }^{74}$ Ibid. (Accessed October 13, 2013)

75 "Flashpoints: Security in East and South China Seas," Center for New American Security, http://www.cnas.org/flashpoints/timeline (Accessed December 5, 2013)

${ }^{76}$ Fackler, Martin, “Japan is Flexing its Military Muscle to Counter Rising China,” The New York Times, November 26, 2012, http://www.nytimes.com/2012/11/27/world/asia/japan-expands-its-regional-militaryrole.html?pagewanted=all (Accessed September 20, 2013)
} 
3. While Japan has been a significant investor in Southeast Asia, its political weight has been relatively negligible for many decades. This was a result of the fact that many of the countries in Southeast Asia endured brutal occupations by Japanese Imperial forces during WWII which nurtured strong distrust among the locals towards Japan. ${ }^{77}$ However, decades of Official Development Assistance (ODA) and investment from Japan to these countries have done much to normalize relations and create a more

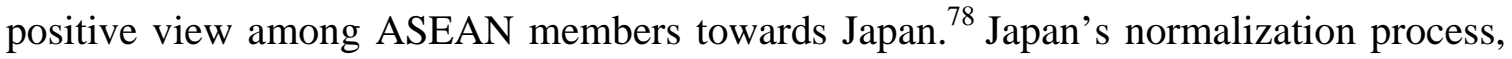
which begun in the early 1990s, has brought a new period of political and military engagement in the region. This engagement has predominantly taken the form of peacebuilding activities under the umbrella of the United Nations. The Japanese Self-Defense Forces (JSDF) have participated in U.N. missions to Cambodia in 1992 and Timor-Leste in 2002. ${ }^{79}$ In recent years Tokyo has also been actively engaged in providing securityoriented development assistance for Southeast Asian states in order to support maritime capacity-building. ${ }^{80}$ This indicates that a normalizing Japan wishes to play a more proactive political and security role in the region; something which it was unable or unwilling to do in decades past.

\footnotetext{
${ }^{77}$ Pajon, Celine, “Japan and the South China Sea: Forging Strategic Partnerships in a Divided Region,” Institut Francais des Relations Internationales, Center for Asian Studies, 2013, Pg. 6, http://www.ifri.org/?page=contribution-detail\&id=7555 (Accessed September 20, 2013)

78 “Opinion Poll on Japan in Six ASEAN Countries,” Ministry of Foreign Affairs of Japan, 2008, http://www.mofa.go.jp/region/asia-paci/asean/survey/qa0803.pdf (Accessed November 18, 2013)

79 “The world needs the Japan Self-Defense Forces (JSDF),” Ministry of Defense, 2011, http://www.mod.go.jp/e/publ/pamphlets/ (Accessed November 18, 2013)

${ }^{80}$ Pajon, Celine, “Japan and the South China Sea: Forging Strategic Partnerships in a Divided Region,” Institut Francais des Relations Internationales, Center for Asian Studies, 2013, Pg. 5, http://www.ifri.org/?page=contribution-detail\&id=7555 (Accessed September 20, 2013)
} 


\section{Methodology, Theoretical Framework, and Structure}

\section{Methods}

The methodology that will be employed for the present study will include a theoretical framework grounded in international relations theory, a historical analysis, and case studies. The theory will aid in framing the dynamics of the disputes as well as provide the groundwork for predicting possible outcomes of the disputes. The historical analyses will provide background information concerning the developments of the territorial disputes in recent years among China, Vietnam, and the Philippines. A historical overview of Sino-Japanese security relations will also be provided. Finally, the case studies will be centered on the Philippines and Vietnam and will highlight Japan's increasing interest in establishing security cooperation agreements with each of these countries in order to secure its sea lanes of communications.

Different categories of sources will be used. In the historical analysis, books and journal articles in the historical and security fields will be the main sources of information. For China's military modernization, books and journal articles in the field of strategic and foreign policy will be used. The section on the normalization of Japan will rely on journal articles in the field of international relations and law in order to conceptualize the constitutional limitations under which Japan currently operates. Primary sources and periodicals will help illustrate the securitization of China in Japanese discourse, and how that continues to drive the Japanese normalization process. The primary sources will come from transcripts of different speeches given by Japanese officials, particularly Prime Ministers, Foreign Ministers and Defense Ministers. These sources along with a number of periodicals will also be used in the case studies due to the 
lack of academic sources pertaining to Japan's security cooperation agreements with Southeast Asian countries.

\section{Theoretical Framework}

The present study will rely on the application of Barry Buzan’s and Ole Waever's Regional Security Complex Theory (RSCT) to provide a theoretical framework. RSCT facilitates the understanding of the complex relationships that underpin the countries that will be studied in this research paper. The regional level of analysis provided by the RSCT allows for a clearer understanding of the security dynamics in the region, which can ultimately assist in predicting the outcomes of the numerous disputes that plague the area. An RSC is defined as “a set of units whose major processes of securitization, desecuritization, or both are so interlinked that their security problems cannot be reasonably analyzed or resolved apart from one another." ${ }^{\text {,1 }}$ RSCs are also characterized by "durable patterns of amity and enmity taking the form of subglobal, geographically coherent patterns of security interdependence. The particular character of local RSC will often be affected by historical factors such as long-standing enmities. „ ${ }^{82}$ RSCT contends that geographical proximity intensifies security interaction. Therefore, security interaction between neighbors is stronger than with states in different areas. ${ }^{83}$

Buzan and Waever put forth the idea that Northeast Asia and Southeast Asia began to merge as a single RSC in the 1990s. They identify two factors that facilitated this phenomenon: the end of the cold war and economic integration. The vacuum left by

\footnotetext{
${ }^{81}$ Barry Buzan and Ole Waever, Regions and powers: The Structure of International Security (Cambridge: Cambridge University Press, 2003), Pg. 44

${ }^{82}$ Ibid. Pg. 45

${ }^{83}$ Ibid. Pg. 45-46
} 
the withdrawal of Soviet and American forces from Southeast Asia, and in some respects, Northeast Asia, allowed China to increase its influence and power. Long-standing military links between China and some Southeast Asian countries became strengthened as a result. The second factor came from Japanese investments in Southeast Asia which created economic interdependence in the region, interdependence that increasingly became linked to regional security and stability. Consequently, the two separate regions became a single East Asian Supercomplex (EAS) ${ }^{84}$

Because the EAS is significantly influenced not only by the security relations among the smaller states, but also by the two main regional powers, this paper will assess the security relations between China and Japan. Studying the security dynamic between the two powers will allow for better contextualization of the ongoing disputes and the possible ways in which they may be resolved. Since amity and enmity are important factors in the RSCT, it will be important to understand the history or relations between the two powers as well as the securitization or desecuritization language that is aimed at one another.

\section{Structure and Organization}

The research section of the thesis will be broken down into a number of chapters and subsections. The first chapter will cover Sino-Japanese relations in order to provide some historical background and examine the perceptions they have towards each other. The second chapter will focus on China's military modernization programs as well as its military doctrines and policies towards the SCS. The third chapter will address the Japanese normalization process and how Japan's evolving security needs have promoted

${ }^{84}$ Ibid. Pg. 62 \& 155-156 
an active SCS policy to balance Chinese power. The fourth and fifth chapter will be composed of case studies involving two Southeast Asian countries, the Philippines and Vietnam respectively. These two have been chosen due to the fact that these two countries have been the most active in disputing their claims against China which has resulted in more clashes with the PRC. These are also two of the three Southeast Asian countries which Japan has identified as "key partners for active Japanese security reengagement in Southeast Asia.” ${ }^{85}$ The final chapter will be the conclusion where potential outcomes to the disputes will be addressed and discussed.

\section{Chapter I: Sino-Japanese Security Relations}

\section{Historical Legacy}

China and Japan share a long and distinct history. The proximity between the two countries enabled contact between the two cultures since the first century in the Common Era. Exchanges between China and Japan flourished over the centuries which enabled China to influence much of Japanese development in the form of writing, philosophical traditions, religion and culture. However, the roles of teacher and student were reversed in the $19^{\text {th }}$ century as Japan modernized and China fell into a semi-colonial status under foreign powers. Japan's defeat of China in the First Sino-Japanese War in 1885 was devastating for China which had to pay huge indemnities and cede territories to its former pupil. Full-scale invasion of the Chinese mainland in the 1930s by the Japanese has left a legacy of bitterness which continues to affect their relations in the $21^{\text {st }}$ century. ${ }^{86}$

\footnotetext{
${ }^{85}$ Pajon, Celine, “Japan and the South China Sea: Forging Strategic Partnerships in a Divided Region,” Institut Francais des Relations Internationales, Center for Asian Studies, 2013, Pg. 18, http://www.ifri.org/?page=contribution-detail\&id=7555 (Accessed September 20, 2013)

${ }^{86}$ Emma Chanlett-Avery and others, eds., "Sino-Japanese Relations: Issues for U.S. Policy, Congressional Research Service, 2008, Pg. 3-4, https://www.fas.org/sgp/crs/row/R40093.pdf
} 
The legacy of the atrocities committed by Japan in China during the 1930s until the end of WWII in 1945 remains a point of contention between the two countries. For its part, the CCP leadership believes that Japan has not adequately apologized for the crimes committed during its invasion of China. The Japanese government's failure to pass any kind of resolution admitting to the atrocities committed by its own troops has only strengthened the Chinese belief that Japan has not repented for the actions taken by its soldiers during that tumultuous period. ${ }^{87}$ Another detrimental issue related to this WWII legacy is the fact that Japanese school textbooks habitually diminish the scope of Japanese atrocities during WWII, particularly the crimes that were committed in China during the Nanking rape and the experiments conducted by Unit 731.

This has been a politically charged issue between the two countries for decades now. ${ }^{88}$ Repeated visits by Japanese officials to the Yasukuni Shinto Shrine which honors all Japanese soldiers killed in war, including 14 Class-A war criminals from WWII, has only played to Chinese sensitivities and has created further strains in bilateral ties. During his tenure, CCP Chairman Jiang Zemin requested that Japanese Prime Minister Koizumi refrain from visits to the shrine, but Koizumi ignored the requests and continued to make visits to the Yasukuni shrine throughout his tenure as PM, inciting anger from the

(Accessed September 20, 2013)

${ }^{87}$ Yang, Jian, “China’s Security Strategy Towards Japan: Perceptions, Policies and Prospects,” The Centre for Strategic Studies, Victoria University of Wellington, 2001, Pg. 5, http://www.victoria.ac.nz/css/docs/working_papers/wp17.pdf (Accessed November 5, 2013)

${ }^{88}$ Roy, Denny, “China-Japan Relations: Cooperation Amidst Antagonism,” Asia-Pacific Center for Security Studies, 2004, Pg. 3, http://www.apcss.org/Publications/SAS/AsiaBilateralRelations/ChinaJapanRelationsRoy.pdf (Accessed November 10, 2013) 
Chinese side ${ }^{89}$ However, the most troubling point of contention between China and Japan is the territorial dispute over the Senkaku/Diaoyu Islands. The islands are currently administered by Japan but are claimed by China. These briefly-mentioned historical issues between the two countries have been repeatedly invoked in their political discourse, and increasingly, their security agenda. Therefore, in order to understand Sino-Japanese relations it is important to place them in proper historical context because this provides a framework that allows us to understand their relationship.

\section{Chinese Security Perceptions of Japan}

Chinese security concerns regarding the Japanese have been primarily focused on Taiwan. Many analysts agree that current PLA capabilities are aimed at deterring Taiwan from achieving de jure independence and denying any outside intervention in a Mainland-Taiwan conflict. Particular attention is placed on the United States and its main ally in the region, Japan. The Chinese are wary of the U.S.-Japan alliance for a number of reasons, but it is the Taiwan issue that is of highest concern. In 1997 the U.S. and Japan revised the guidelines for their defense cooperation. This revision allowed for Japan to assist the United States in conflicts outside of Japanese territories. ${ }^{90}$ The Chinese perceived this revision to be problematic for four reasons:

"First, in Japan-US-China triangular relations, Japan intends to sacrifice Chinese security interests for Japan-US relations. The reason is that all military alliances must have an imaginary enemy and it seems the Japan-US alliance is taking China as its imaginary enemy. Second, the revised guidelines and related measures do not exclude Taiwan in their scope. There is therefore a hidden danger of strategic conflicts between China and the US-Japan alliance. Third, the revised guidelines are transforming the Japan-US

\footnotetext{
${ }^{89}$ Roy, Denny, "Stirring Samurai, Disapproving Dragon: Japan’s Growing Security Activity and SinoJapan Relations," Asia-Pacific Center for Security Studies, 2003, Pg. 7-8, http://www.jstor.org/discover/10.2307/30172610?uid=3739256\&uid=2129\&uid=2\&uid=70\&uid= 4\&sid=21101516703917 (Accessed November 5, 2013)

${ }^{90}$ Pyle, Kenneth B., Japan Rising: The Resurgence of Japanese Power and Purpose

(New York: The Century Foundation), Pg. 333
} 
military alliance into an Asian version of NATO. Although Japan's roles will mainly be to provide logistics and rear-area support, Japan is actually "sailing out in a borrowed boat". Therefore, Japan's policies of "homeland defense" and "not to be a military power" no longer exist. Finally, the revised guidelines and related measures have strengthened domestic demands for revising Japan’s constitution." ${ }^{91}$

The fact that the revision does not exclude Taiwan in its scope has garnered criticism from China because it creates the possibility that it may have to contend not only with American but also Japanese involvement in a cross-strait conflict. Exacerbating the issue was a 2005 joint statement made by the United States and Japan which indicated that there should be a "peaceful resolution" to the Taiwan Strait issue. Considering that Taiwan is a core national interest for the PRC, the Chinese responded by enacting the Anti-Secession Law which legitimized non-peaceful means to prevent Taiwanese independence. ${ }^{92}$ This issue has been one of the main drivers for the PLA's heavy investment in missile technologies, in particular the Anti-Ship Ballistic Missile (ASBM) program in order to deter any involvement by U.S. and Japanese forces if such conflict were to occur.

The fact that the Chinese perceive the U.S.-Japan alliance as a means of containing Chinese military modernization has only been exacerbated by the joint development of a Ballistic Missile Defense (BMD) system between the two allies. The program has solicited criticism from the Chinese side because it perceives that this "missile shield" is aimed at China. Though the Japanese side agreed to the BMD

\footnotetext{
${ }^{91}$ Yang, Jian, “China’s Security Strategy Towards Japan: Perceptions, Policies and Prospects,” The Centre for Strategic Studies, Victoria University of Wellington, 2001, Pg. 7, http://www.victoria.ac.nz/css/docs/working_papers/wp17.pdf (Accessed November 5, 2013)

${ }^{92}$ Atanassova-Cornelis, Elena, "Political and Security Dynamics of Japan-China Relations: Strategic Mistrust, Fragile Stability and the US Factor,” Political Studies Association, 2010, 5, http://www.psa.ac.uk/Proceedings/2010 (Accessed November 10, 2013)
} 
programs on the grounds that it needed deterrence against a nuclear-armed North Korea, the Chinese claim that current Japanese missile-interception capacity exceeds current North Korean missile capabilities. Consequently, they believe that the Japanese have "great-power" ambitions and that the true aim of the program is to reduce PLA missile capabilities. Japan currently operates six Aegis-equipped destroyers, which are further supported by over a dozen American Aegis destroyers deployed in the Pacific. The Aegis system is a countermeasure platform capable of intercepting incoming missiles over a vast area, which could theoretically negate any incoming missile threat. Chinese analysts are quick to point out, that out of the six Aegis-equipped destroyers Japan currently deploys, Japan only needs two in order to intercept incoming missiles from both China and North Korea. Some go further, claiming that a single Aegis-equipped destroyer is enough to provide full coverage over the Japanese archipelago. ${ }^{93}$

It is clear that China views Japan as a potential threat to its security and is very suspicious of any steps taken by Japan to become a "normal” power. The PRC contends that although Japan is supposedly "disarmed," it maintains a large land force that numbers 250,000, which is comparable to Britain, and has an annual defense budget of over $\$ 50$ billion; among the highest in the world. ${ }^{94}$ The Chinese perception of a Japanese threat to its security has only strengthened their resolve to modernize their military as

\footnotetext{
${ }^{93}$ Yoshibara, Toshi and Holmes, James R., Red Star Over The Pacific: China's Rise and The Challenge to U.S. Maritime Strategy (Annapolis: Naval Institute Press, 2010), Pg. 112-113

${ }^{94}$ Roy, Denny, "Stirring Samurai, Disapproving Dragon: Japan’s Growing Security Activity and SinoJapan Relations," Asia-Pacific Center for Security Studies, 2003, Pg. 3, http://www.jstor.org/discover/10.2307/30172610?uid=3739256\&uid=2129\&uid=2\&uid=70\&uid= 4\&sid=21101516703917 (Accessed November 5, 2013)
} 
quickly as possible in order to deter or balance any actions taken by the Japanese to fully normalize itself as a military power.

\section{Japanese Security Perceptions of China}

China’s modernization program has been met by suspicion on many levels by the Japanese. Tokyo is wary of Beijing's defense expenditures which have seen double-digit growth for over two decades now. China's growth as an economic power and continual progress in becoming a military power has taken place during a period in which Japan’s own economy has stagnated; basically, a "modern Japan has never had to deal with a strong China. World attention turned from the Japanese miracle to fascination with China in a way that was psychologically jarring for Japan.”95 Subsequently, Japan has come to perceive China as a security threat with the Japanese Defense Agency (JDA) making a public statement in 2004 alluding to the possibility of a future armed conflict with China. ${ }^{96}$ Chinese incursions into the Japanese-administered Senkaku Islands have only increased the perception among Japanese officials that a modernized PLA has become more assertive and is a potential threat.

These islands have been a source of contention between the two sides since the United States handed administrative control of the islands to Japan in 1972. The PRC claims that the islets belonged to the Taiwanese provincial jurisdiction which was ceded to Japan by the ruling Qing Dynasty in the Treaty of Shimonoseki after China lost the

\footnotetext{
${ }^{95}$ Pyle, Kenneth B., Japan Rising: The Resurgence of Japanese Power and Purpose (New York: The Century Foundation), Pg. 313

${ }^{96}$ Xinbo, Wu, "The End of the Silver Lining: A Chinese View of the U.S.-Japanese Alliance," The Washington Quarterly 29:1 (2005), Pg. 123, http://www.brookings.edu/ /media/research/files/articles/2006/12/winter\%20china\%20xinbo/xinb o20060101.pdf (Accessed September 20, 2013)
} 
First Sino-Japanese War in 1895. According to the Chinese the Diaoyu Islands, as they are known in China, have been under Chinese control since the Ming Dynasty. Because the Treaty of Shimonoseki was part of the "unequal treaties" that were rendered void at the end of WWII, China believed that they should have been rightfully returned.

The Japanese claim to the islands, which are known as the Senkakus in Japan, is made because Japan gained control of the Ryukyu island chain in 1879 and formally annexed them in 1895. Since they claim that the Senkakus are formally part of the Ryukyu island chain, they rightfully belong to Japan. The fact that the U.S. took no position on the legal status of the islands when they handed administrative control to Japan has created a problem for the Chinese. What further complicates this dispute is a United Nations survey from 1968 which claimed that the sea surrounding the islands contained vast oil and gas reserves. ${ }^{97}$ Japan's lack of energy resources and China's growing dependence on energy imports to fuel its economy have raised the stakes on the sovereignty of the islands and the surrounding seas. Beyond the energy security implications of the islands, this territorial dispute has been exacerbated time and time over the years as Chinese vessels and aircraft have been found operating in the vicinity of the islands. Sometimes these encroachments have been dangerous as the Japanese Coast Guard (JCG) has had to interdict Chinese vessels. Encounters such as these can potentially result in minor clashes or even an escalation of force.

The importance of submarine forces to China has added a new dimension to the tension in the conflict between the two countries as there have been a number of Chinese

\footnotetext{
${ }^{97}$ Bush, Richard C. The Perils of Proximity: China-Japan Security Relations
}

(D.C.: Brookings Institution Press, 2010) , Pg. 70-71 
research ships conducting surveys in the area which have the potential to map the ocean floor. This becomes a critical security concern for Japan because of the fact that those maps can be used by PLA submarines to conduct operations in the region. As a result, the JCG has opted to deploy larger ships to the area in order to deter further Chinese incursions. ${ }^{98}$ As previously mentioned, increased PLA capabilities resulting from its modernization programs have also raised concerns among Japanese officials who believe that China poses a threat to Japan's sea lines of communication (SLOC). Being a small island country, Japan has little to no natural resources. It relies on energy imports for the vast majority of its oil and gas consumption. The increased power-projection capabilities of the PLA in both air and sea create anxieties in Japan because of the possibility of Chinese interruption of the SLOC. ${ }^{99}$ Because of this, Taiwan has become an important strategic asset regarding the security of the Japanese SLOC. According to Japanese military analyst Shigeo Hiramatsu:

\begin{abstract}
“Taiwan serves as a critical component of Japan’s sea-lane. If Taiwan were integrated into China, the South China Sea would become China's Sea, bringing the sea lane to the Middle East and Southeast Asian countries under strong Chinese influence. China would have more say over Japan's Nansei Islands and the East China Sea. If the East China Sea were brought under Chinese influence, the Yellow Sea would lose access to high seas and become China's inland sea, while the Korean Peninsula will fall under the Chinese sphere of influence. Moreover, China will probably use Taiwan as a stepping-stone and make its way into the Pacific....Taiwan is Japan's 'lifeline’,100
\end{abstract}

This essentially means that the Japanese fear that growing PLA capabilities may create a power imbalance across the straits which may result in strategic losses for Japan.

\footnotetext{
98 Ibid. Pg. 72

${ }^{99}$ Atanassova-Cornelis, Elena, "Political and Security Dynamics of Japan-China Relations: Strategic Mistrust, Fragile Stability and the US Factor,” Political Studies Association, 2010, Pg. 5, http://www.psa.ac.uk/Proceedings/2010 (Accessed November 10, 2013)

${ }^{100}$ Bush, Richard C. The Perils of Proximity: China-Japan Security Relations (D.C.: Brookings Institution Press, 2010) , Pg. 84
} 
China’s geographically dominant position in East Asia's coastal periphery and its growing military capabilities can eventually present a realistic threat to Japan’s shipping lanes by restricting access to resources abroad. ${ }^{101}$ The fact that the Japanese military establishment sees Taiwan as a strategic asset to secure its SLOC lends credence to Chinese fears of a possible Japanese intervention in a cross-straits conflict.

As a result of the numerous Chinese incursions into the Senkaku area and the ongoing PLA modernization programs, the Japanese decided to formally terminate the ODA program tailored for China in 2008. ${ }^{102}$ The ODA program for China began in 1979 shortly after the Sino-Japanese Rapprochement of 1972 in the wake of President Nixon’s visit to China. This program consisted of low-interest loans as well as grants for China which were aimed at developing infrastructure such as airports, seaports and roads which directly benefited Japanese firms that were investing on the mainland. The origins of this program began in 1972 when the Chinese and Japanese were normalizing their relations.

One of the pressing issues during the negotiations was the war reparations which China felt Japan owed for the damage caused during the Second Sino-Japanese War. However, from the Japanese perspective the Chinese had given up the rights to ask for reparations in 1952 when the Nationalist government, which was the internationally recognized government of China at the time, signed the Japan-Republic of China Treaty. The fact that the Japanese delegation brought this treaty up angered Chairman Mao Zedong and Premier Zhou Enlai. Nevertheless, because the Chinese felt that

\footnotetext{
${ }^{101}$ Pyle, Kenneth B., Japan Rising: The Resurgence of Japanese Power and Purpose (New York: The Century Foundation, 2007), Pg. 335

${ }^{102}$ Atanassova-Cornelis, Elena, "Political and Security Dynamics of Japan-China Relations: Strategic Mistrust, Fragile Stability and the US Factor,” Political Studies Association, 2010, Pg. 8, http://www.psa.ac.uk/Proceedings/2010 (Accessed November 10, 2013)
} 
rapprochement with the United States and Japan was more important, they agreed to waive the issue of reparations. Once Deng Xiaoping became the Chairman, he expressed displeasure with the fact that China had waived the issue of reparations during negotiations, but was not too vocal due to the fact that both Mao and Zhou still remained important figures to the memory of the party. In 1978 Deng made a visit to Japan and motioned that China would be open to low-interest loans from Japan to help in his modernization initiatives. He was more explicit in a 1987 when he commented that Japan had an obligation to help China in its development. He stated that Japan "has the biggest debt to China. In 1972 China did not ask for reparations. Frankly speaking, we harbor dissatisfaction over this point." ${ }^{103}$ The Japanese agreed that assistance in the form of low interest loans and grants would create good will between both sides and by the time the program ended the Chinese had received billions in ODA.

\section{Chapter II: China's Military Modernization}

\section{Background}

Since Deng Xiaoping took over the reins of the Chinese Communist Party in 1978, China has undergone profound economic reforms. These economic reforms have proven to be extremely successful as China's economy has grown by more than $9 \%$ annually for the better part of three decades. ${ }^{104}$ By 2010 China had surpassed Japan as the world's

\footnotetext{
${ }^{103}$ Pyle, Kenneth B., Japan Rising: The Resurgence of Japanese Power and Purpose (New York: The Century Foundation, 2007), Pg. 324-327

104 Ross, Robert S., "Balance of Power Politics and the Rise of China: Accommodation and Balancing in East Asia,” Security Studies 15:3 (2006) , Pg. 376, http://www.tandfonline.com/doi/abs/10.1080/09636410601028206\#preview (Accessed November 1, 2013)
} 
second largest economy behind the United States. ${ }^{105}$ This economic growth has benefited the People's Liberation Army (PLA) which has used this new-found wealth to push for comprehensive modernization programs across all of its service branches. Military spending in China has grown by double digits annually since the early 1990s. The Department of Defense (DOD) estimated that China’s defense budget for 2011 was \$160 billion and will continue to rise for the foreseeable future. ${ }^{106}$ However, the current level of defense spending has not always been the norm. During the initial phase of economic reforms in the late 1970s and throughout the 1980s, China's military ranked as the least important among the proposed "four modernizations" (industry, agriculture, defense, and science and technology) under the Deng Xiaoping regime. ${ }^{107}$ Much of the policies being enacted during this time period were concentrated on economic growth and modernization of the country's industries. Nevertheless, while the economy remains the main focus of Chinese policymaker's agenda today, the military has begun to take a more prominent role in the annual budget of the PRC.

\section{Catalysts for Modernization}

The increasingly prominent role of the military was the result of two key events that occurred in the 1990s and served as the catalysts for PLA modernization. The first

\footnotetext{
105 Barboza, David, “China Passes Japan as Second-Largest Economy,” The New York Times, August 15, 2010 http://www.nytimes.com/2010/08/16/business/global/16yuan.html?pagewanted=all (Accessed October 30, 2013)

106 “Annual Report To Congress: Military and Security Developments Involving the People’s Republic of China 2011.” Department of Defense, 2011, Pg. 41. http://www.defense.gov/pubs/pdfs/2011_CMPR_Final.pdf (Accessed November 10, 2013)

${ }^{107}$ Bergsten, Fred C. et al., China's Rise: Challenges and Opportunities (Washington D.C.: The CSIS Press 2009) Pg. 197
} 
catalyst began with the Gulf War in 1991. The Chinese High Command was stunned by the overwhelming force that the U.S. and its allies were able to bring to Saddam Hussein's military. The allies employed technologies that had not yet seen combat use but the results were clear: absolute decimation of the Iraqi forces. The American forces along with their Allies were able to penetrate Iraqi airspace with impunity by deploying their sophisticated stealth fighters/bombers. Naval forces were able to launch cruise missiles and other precision weaponry while remaining outside the range of the Iraqi countermeasures. The use of electromagnetic warfare attacks and computer viruses to infect enemy systems completely blinded Iraqi command and control networks rendering them unable to coordinate defenses or counter Allied attacks. Equally impressive was the use of global positioning systems (GPS) by the Allies to coordinate their movements effectively and efficiently, something Iraqi forces were incapable of achieving. Chinese generals were forced to admit that the PLA was ill-prepared to conduct war against any modern military force. ${ }^{108}$ The leaders of the CCP acknowledged the need to properly modernize the PLA so that it could operate effectively in the $21^{\text {st }}$ century.

The second catalyst that fully cemented the modernization programs in the PRC was the Taiwan Straits Crisis of 1996. In March of that year the PLA's Second Artillery Corps (SAC), which is in charge of the strategic missiles in the military's inventory, began firing short-range ballistic missiles (SRBM) within miles of two vital Taiwanese harbors, Keelung in the north and Kaohsiung in the south. The reason behind the provocation was Taiwan's first democratic elections. The PRC wanted to dissuade the

\footnotetext{
108 Shambaugh, David. Modernizing China's Military: Progress, Problems, Prospects (Los Angeles: University of California Press 2004), Pg. 1-2
} 
Taiwanese people from proceeding with the elections by undermining its government; therefore, it resorted to intimidation conducting missile tests off the Taiwanese coast. The United States responded by sending two aircraft carrier groups to the vicinity. Once near Taiwan, American forces began to conduct military exercises and monitoring operations on the PLA in order to discourage further missile launches. This incident gave new urgency to the modernization programs in the PLA because Chinese leaders now believed that they would definitively have to contend with the United States if they chose to take Taiwan by force. ${ }^{109}$ These two instances served as the catalysts of the modernization programs. It is at this point that the PLA decided to revise its operating doctrines and strategies and began a comprehensive foreign weapon acquisition program as well as a complete overhaul and modernization of its indigenous industrial military complex.

\section{Military Doctrines}

Among the first modernizing measures taken by the PLA was the overhaul of its underlying doctrines and strategies. While it is difficult to ascertain completely accurate pictures of the PLA's strategies and doctrines, we have enough information from its white papers to know the three publicly acknowledged doctrines. These are: "Active Defense”, "Local War under Conditions of Informatization,” and "People’s War." These doctrines were formulated from the ground up or modified by PLA officers in order to allow the military to operate using modern tactics and equipment. "Active Defense" is a hotly debated concept. On the surface it is meant to be a purely defensive

\footnotetext{
109 Ibid, Pg. 3-4

110 Cordesman, Anthony, Yarosh, Nicolas S. “Chinese Military Modernization and Force Development: A Western Perspective.” Center for Strategic and International Studies, 2012 Pg. 32. http://csis.org/publication/chinese-military-modernization-and-force-development-0 (Accessed November 11, 2013)
} 
doctrine, essentially claiming that the Chinese would not be the first to initiate a conflict. However, part of the doctrine also states that an enemy's attack does not necessarily have to be kinetic in order to warrant countermeasures. What this means is that the PRC can perceive something as an attack even if it's political or economic in nature. According to the PLA publication: Science of Military Strategy, “Active Defense” entails the following:

\begin{abstract}
"Strategically, we would fight only after the enemy has struck. But when foreign enemies forced war on us, we should be able to deal out powerful counterattack and stop the enemy's offence in predetermined areas. After gradually depriving the enemy of his strategic initiative, we would change strategic defensive to strategic offensive, so as to utterly defeat the enemy's invasion."111
\end{abstract}

While "Active Defense" provides the overarching doctrine for the military, “Local War under Conditions of Informatization” provides the definite concept of how the PLA will approach combat. The basic tenets of "Local War under Conditions of Informatization" revolve around the perception that near-future wars will take place primarily along China's periphery. They will also be of short duration and limited in scope, hence the "local" aspect of the doctrine. The Informatization part of the doctrine invokes the fact that warfare in the $21^{\text {st }}$ century, no matter the scope, will require advanced technology to effectively win an engagement. ${ }^{112}$ The doctrine highly emphasizes the asymmetrical nature of the balance of power between China and its potential adversaries: Taiwan, U.S., and Japan. The PLA understands that its own capabilities, while vastly improved over the past decades, still remain technologically inferior compared to modern militaries. ${ }^{113}$ Keeping this in mind, the Chinese have sought

${ }^{111}$ Ibid, Pg. 33

112 Ibid, Pg. 33-34

113 “Annual Report To Congress: Military and Security Developments Involving the People's Republic of China 2011.” Department of Defense, 2011, Pg. 22. http://www.defense.gov/pubs/pdfs/2011_CMPR_Final.pdf 
to acquire technology and weapons that allow them to attack vital weaknesses in their enemies' military. One of the fundamental principles of this doctrine is "anti-access and area denial” (A2/AD). This concept calls for particular weapons which allow China to impede, restrict, or deter enemy movements in the area it wishes to exert control over; this is particularly relevant in the case of Taiwan and trying to keep American and Japanese forces from intervening should the PRC resort to using force to retake the island.

The last of the three main doctrines currently operational in the PLA is "People's War”. This is by far the oldest of the three doctrines and has been modified to encompass the realities of $21^{\text {st }}$ century warfare. Dating back to the 1930s when fighting the Japanese in the Second Sino-Japanese War, the doctrine emphasized the importance of the participation of the general population in different aspects of warfare. Much of this remains true today; it essentially calls for the "mobilization of the Chinese population and the country's natural and industrial resources in times of emergency to support the armed forces." ${ }^{114}$ A publication by the Science of Second Artillery Campaigns elaborates on how this doctrine is put into practice:

“...within the battle zone, the financial potential, mechanical maintenance capability, loading and unloading transportation capability, medical first--aid ability, in addition to the quantity and quality of the population, would all constitute extremely direct influence towards the logistics, equipment technical support and personnel replenishment.”"115

(Accessed November 10, 2013)

${ }^{114}$ Blasko, Dennis J. The Chinese Army Today: Tradition and Transformation for the $21^{\text {st }}$ Century (New York: Routledge 2012), Pg. 15, 119-120

115 Cordesman, Anthony, Yarosh, Nicolas S. "Chinese Military Modernization and Force Development: A Western Perspective.” Center for Strategic and International Studies, 2012 Pg. 35. http://csis.org/publication/chinese-military-modernization-and-force-development-0 (Accessed November 11, 2013) 
Although the CCP recognizes three doctrines and accompanying strategies officially, it is clear that its foreign weapons acquisitions and indigenous development heavily favor "Local War under Conditions of Informatization" and its A2/AD component.

\section{Acquisitions and Indigenous Production}

The PLA has pursued the purchase or the development of weapons systems which can properly fulfill its A2/AD requirements. Key imports have been: 300+ Sukhoi fighter jets, 12 Kilo class submarines, four Sovremenny-class missile cruisers (See Figures 1\&2), and about 1000 S-300 surface-to-air missile (SAM) batteries which are able to simultaneously track over 100 targets. ${ }^{116}$ The submarines come equipped with state of the art anti-ship missiles (ASM) such as the SS-N-22 Sunburn and SS-N-27 Sizzler against which the U.S. Navy has yet to find an effective way to defend its aircraft carriers. ${ }^{117}$ The SAM batteries and Sukhoi fighters are aimed at deterring aerial incursions into Chinese territory or area of engagements. Subsequently, these weapons have become the centerpieces of the PLA acquisition program in recent years due to the fact that they are among the most modern platforms currently deployed by the military.

One of the key indigenous programs that have been successful is the Yuan-class diesel submarine. In order to give some perspective on the capabilities of the submarine, Jane’s Navy International, an intelligence analyst company, reported that the Yuan-class submarines may be equipped with air-independent propulsion (AIP). Air-independent Propulsion allows diesel submarines to remain submerged for weeks at a time, which

\footnotetext{
${ }^{116}$ Fisher, Richard D. Jr. China's Military Modernization: Building for Regional and Global Reach (Stanford: Stanford University Press 2010), Pg. 90

${ }^{117}$ Rajagopalan, Rajeswari P., "The Emerging Balance of Power in Asia: Conflict or Cooperation?” Centre for Land Warfare Studies 2009, Pg. 9-10, http://www.claws.in/index.php?action=Claws\%20Paper (Accessed October 30, 2013)
} 
decreases their chance of detection by enemy forces. ${ }^{118}$ Technology such as the AIP is very advanced and only the most modern militaries have such systems employed in their services. The area-deniability factor of this weapon is that it poses a threat to any ships passing through their operational zone. Together with the Kilo and Yuan class submarines, the Chinese navy currently operates 60 submarines and has plans to expand its fleet in the coming years, greatly increasing its A2/AD capabilities. ${ }^{119}$

The PLA has also set up an extensive conventional cruise and ballistic missile capability to make up for its lack of aerial and naval superiority. By making use of its significant geographical advantage as a continental power and its capable missile development programs, China has produced an impressive stockpile of short to long range missiles capable of striking American assets on land, air and sea. ${ }^{120}$ The Defense Intelligence Agency (DIA) estimated that by 2006 China had over 900 SRBMs and was increasing its inventory annually at a rate of more than 100. These SRBMs have a range of less than $1000 \mathrm{~km}$ but effectively cover most of the Chinese coast and will be complemented in the future by mid-range ballistic missiles (MRBM) capable of reaching targets 3000km away. ${ }^{121}$ Coupled with the S-300 SAM systems, the Sunburn, and Sizzler

\footnotetext{
${ }^{118}$ Chang, Amy. "Indigenous Weapons Development in China’s Military Modernization.” U.S.-China Economic and Security Review Commission Staff Research Report, 2012, Pg. 11. http://www.uscc.gov/researchpapers/2012/China-Indigenous-Military-Developments-Final-Draft03-April2012.pdf (Accessed November 12, 2013)

119 "The People’s Liberation Army Navy: A Modern Navy with Chinese Characteristics," Office of Naval Intelligence, 2009, Pg. 18, https://www.fas.org/irp/agency/oni/pla-navy.pdf (Accessed November 13, 2013)

${ }^{120}$ Easton, Ian, “China’s Military Strategy in the Asia-Pacific: Implications for Regional Stability,” The Project 2049 Institute, 2013, 5-6, http://www.project2049.net/documents/China_Military_Strategy_Easton.pdf (Accessed November 13, 2013)

121 “Annual Report To Congress: Military Power of the People’s Republic of China
} 
ASM, the PLA is quickly creating an effective A2/AD umbrella which can potentially impede the freedom of movement by the U.S. and Japan in the event of a conflict.

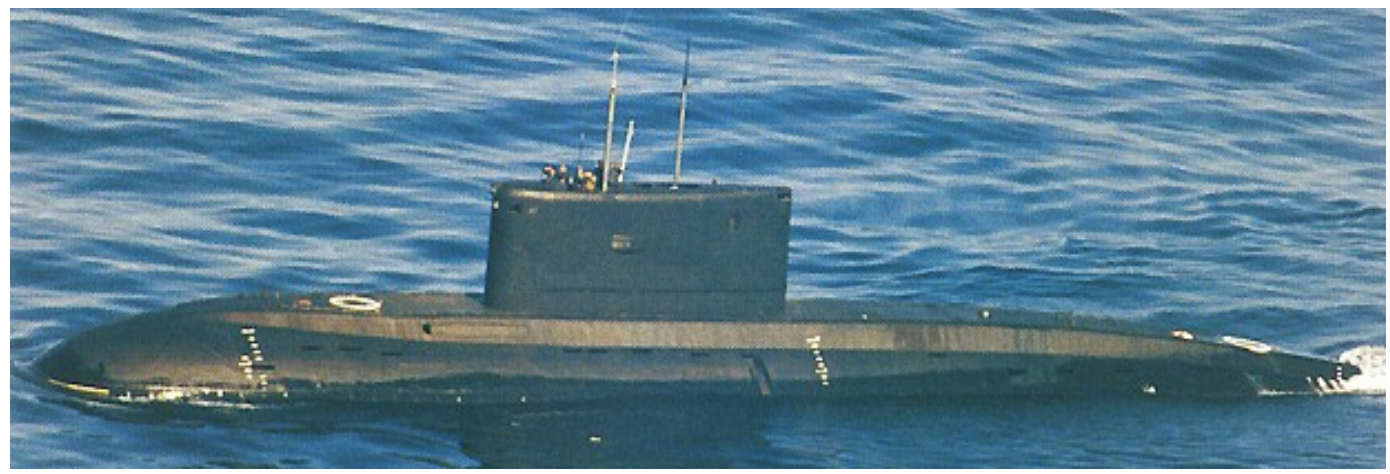

Figure 1. Kilo-Class Submarine.

Source Naval-Technology.com: http://www.naval-technology.com/projects/kilo877/kilo8772.html

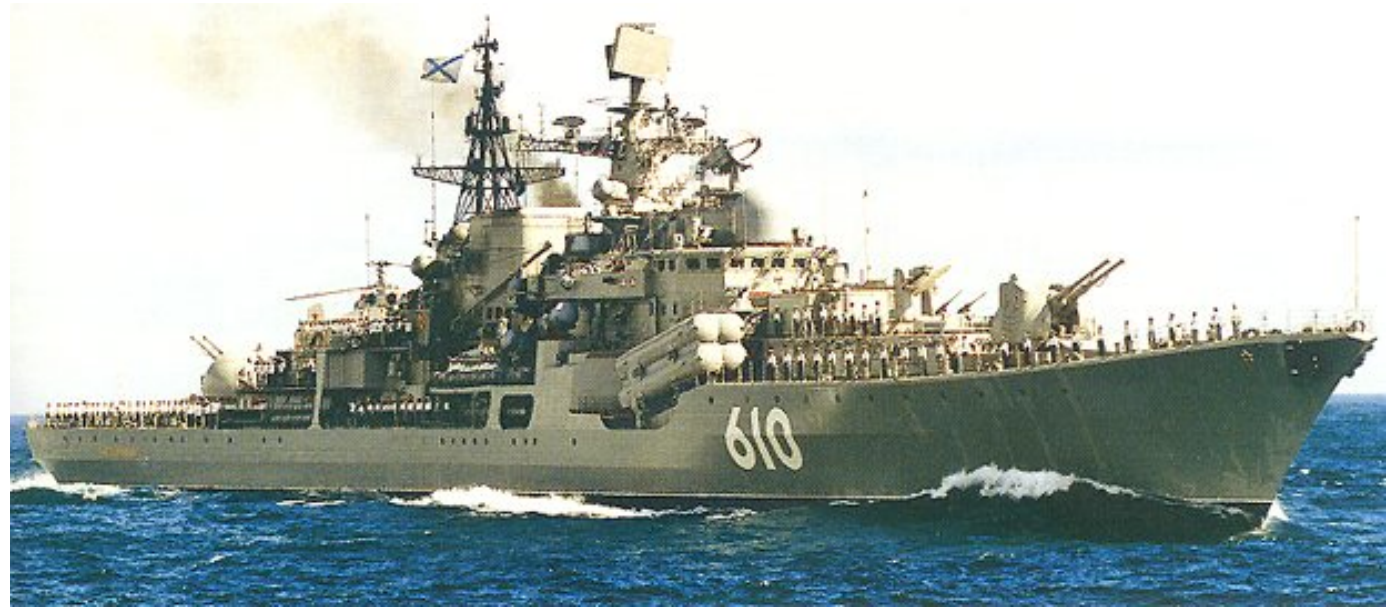

Figure 2. Sovremenny-Class destroyer.

Source Naval-Technology.com: http://www.navaltechnology.com/projects/sovremenny/sovremenny5.html

2007.” Department of Defense, 2007, Pg. 17, http://www.defense.gov/pubs/pdfs/070523-chinamilitary-power-final.pdf (Accessed November 12, 2013) 


\section{The Assassins Mace}

The term Assassin's Mace emanates from Chinese folklore about a hero who wields such a weapon in order to overcome a more powerful opponent. In military terms it is strategy that calls for the capacity to "rapidly and decisively seize the initiative and turn the tide to one's advantage when confronting a conventionally superior foe.”122 Assassin's Mace is essentially an extension of $\mathrm{A} 2 / \mathrm{AD}$ but is more focused on asymmetrical and unconventional approaches to warfare. The core concept of keeping the enemy away from key interests encapsulated by $\mathrm{A} 2 / \mathrm{AD}$ is augmented by the capability to land a decisive blow on the enemy should they wish to engage. In this regard Assassin's Mace also encompasses indigenous research and development of weapons that can effectively deter the opponent or strike a decisive blow should tensions escalate to armed conflict. ${ }^{123}$ Because the focus of these weapons is modern regional militaries, particularly the U.S. and Japan, China has sought to identify their key military assets that while powerful are also very vulnerable; assets like satellites, command and control centers, American Nimitz-class super carriers and Wasp-class Landing Helicopter Docks or Japanese helicopter destroyers like the Hyuga and Izumo-class Helicopter Destroyers.

Key Assassin’s Mace-type platforms that have been identified by the Pentagon have been Anti Satellite weapons (ASAT), sea mines, and conventional ballistic missiles. Regarding ASAT technology, the PLA proved in 2007 that it is capable of taking down

\footnotetext{
${ }^{122}$ Rehman, Iskander, “Deflecting the Assassin’s Mace: The Pentagon’s New AirSea Battle Concept and its Strategic Relevance to India,” Institute for Defense Studies and Analyses, 2010, Pg. 4, http://idsa.in/issuebrief/AirSeaBattleConceptanditsRelevancetoIndia_irehman_070710 (Accessed November 12, 2013)

${ }^{123}$ Bruzdzinski, Jason E., “Demystifying Shashoujian: China’s Assasin’s Mace Concept,” MITRE, 2005, Pg. 312, http://www.mitre.org/publications/technical-papers/demystifyingshashoujian-chinas-assassins-mace-concept (Accessed November 12, 2013)
} 
satellites with missiles. The PLA also appears to be "developing other kinetic and directed-energy (e.g., lasers, high-powered microwave, and particle beam weapons) technologies for ASAT missions. Foreign and indigenous systems also give China the capability to jam common satellite communications bands and GPS receivers." ${ }^{\text {} 124}$ Weapons like these could potentially blind the U.S. and Japan in the event of an armed conflict and, therefore, have the potential to change its course.

The PLA Navy also has a current estimated inventory of 50,000-100,000 mines of which there are over thirty varieties. These range from traditional moored or drifting mines to sophisticated remote controlled and rising mines. These mines can be directed to a location and sit at the bottom of the ocean waiting for an acoustic or magnetic signature to trigger its launching mechanism. Rising mines are particularly troubling because they are essentially torpedoes that rise from the bottom of the ocean to strike the unsuspecting target. These mines are said to be very effective anti-submarine weapons. ${ }^{125}$ Coupled with the fact these mines are much more difficult to sweep and that the U.S. does not currently have significant mine countermeasure assets in the region, the PLA Navy hopes that in the event of a conflict it can swiftly lock American vessels out of its operational zone in order to achieve its goal. ${ }^{126}$ However, it is important to note that Japan currently operates 26 mine countermeasures (MCM) vessels, which is indicative of its concern with China's vast sea mine arsenal. It is

\footnotetext{
124 “Annual Report To Congress: Military and Security Developments Involving the People’s Republic of China 2011.” Department of Defense, 2011 Pg. 37. http://www.defense.gov/pubs/pdfs/2011_CMPR_Final.pdf (Accessed November 10, 2013)

${ }^{125}$ Andrew S. Erikson, Lyle J. Goldstein, and William S. Murray, "Chinese Mine Warfare: A PLA Navy ‘Assassin’s Mace’ Capability,” Naval War College, 2009, Pg. 11\& 20, http://www.usnwc.edu/Research---Gaming/China-Maritime-StudiesInstitute/Publications/documents/CMS3_Mine-Warfare.aspx (Accessed November 13, 2013)

${ }^{126}$ Ibid. Pg. 47-48
} 
also “illustrative of Tokyo’s strong commitment to MCM that all these craft are of 1980s or newer vintage.” ${ }^{27}$ This essentially makes Japan the best-equipped state in the region to meet any potential PLA mine-laying operation.

The last piece of China's Assassin's Mace arsenal that is publicly known is the development of the Dong Feng-21D (DF-21D) ASBM. They PLA has prioritized ballistic and cruise missile programs to serve as a deterrent to formal Taiwanese independence or any involvement by outside forces in a mainland-Taiwan conflict. The DF-21D is a notable platform because this missile is theoretically capable of attacking large naval vessels such as the American Nimitz-class aircraft carriers or the Japanese Hyuga and Izumo class helicopter destroyer. The missile has maneuverable reentry vehicle (MaRV) technology which would allow the warhead to maneuver or change its trajectory once it reenters the atmosphere, thereby enhancing its evasiveness. This technology would increase the missile's survivability by making it more effective against existing defensive countermeasures. $^{128}$

The Assassin's Mace line of weaponry is exotic and has been product of a conscious understanding that China's capabilities do not yet match those of the U.S. and Japan. Although it appears that China does not seem intent on challenging American supremacy globally, it is concerned that the U.S. and Japan may challenge its position as a regional power in the coming decades. However, most of the details regarding Assassin's Mace weapons remain classified. Nevertheless, the Pentagon, the Japanese

\footnotetext{
${ }^{127}$ Ibid. Pg. 50

128 “Annual Report To Congress: Military and Security Developments Involving the People’s Republic of China 2011.” Department of Defense, 2011, Pg. 3-4, http://www.defense.gov/pubs/pdfs/2011_CMPR_Final.pdf (Accessed November 10, 2013)
} 
Ministry of Defense, and other analysts continue to monitor their development closely because of their potential to alter the status quo.

\section{China's South China Sea Policy}

As mentioned above, China claims sovereignty over the entirety of the SCS land features. It currently occupies the following 7 reefs in the Spratly archipelago:

(International name/Chinese name)

1. Cuarteron Reef or Huayang Reef

2. Fiery Cross Reef or Yongshu Reef

3. Hughes Reef or Dongmen Reef

4. Gaven Reefs or Nanxun Reef and Xinan Reef

5. Johnson South Reef or Chigua Reef

6. Mischief Reef or Meiji Reef

7. Subi Reef or Zhubi Reef ${ }^{129}$

The PRC maintains military facilities in all 7 of these features. Most installations have concrete buildings, helipads, antennas, search lights, radars, and naval guns. ${ }^{130}$

Furthermore, China has occupied the Paracels since its eviction of Vietnamese forces in 1974. In the Paracel Islands China has established the Sansha administrative city on Woody Island, known as Yongxing in Chinese. Nearly 1000 residents currently live there and the PRC plans to build:

“a municipal office complex, an airport expansion, a military supply facility and supply hub for fishery and maritime surveillance vessels. It also intends to build a new port, a desalination plant capable of handling 1,000 tonnes of sea water daily, a 500-kilowatt solar power station, as well as "environmentally friendly" rubbish and waste-water treatment facilities."131

129 “Territorial Claims in the Spratly and Paracel Islands,” Global Security, http://www.globalsecurity.org/military/world/war/spratly-claims.htm (Accessed September 20, 2013)

${ }^{130}$ Banlaoi, Rommel C., Philippines-China Security Relations: Current Issues and Emerging Concerns (Quezon City: Philippine Institute for Peace, Violence and Terrorism Research, 2012), Pg. 65

${ }^{131}$ Chan, Minnie, “Major Development Plan for Woody Island Unveiled,” South China Morning Post, 2014, http://www.scmp.com/news/china/article/1074996/major-development-plan-woody-islandunveiled (Accessed January 29, 2013) 
China hopes that the settlement on the island will demonstrate control of the area and its inhabitability in order to cement its claims (See Figure 3). ${ }^{132}$

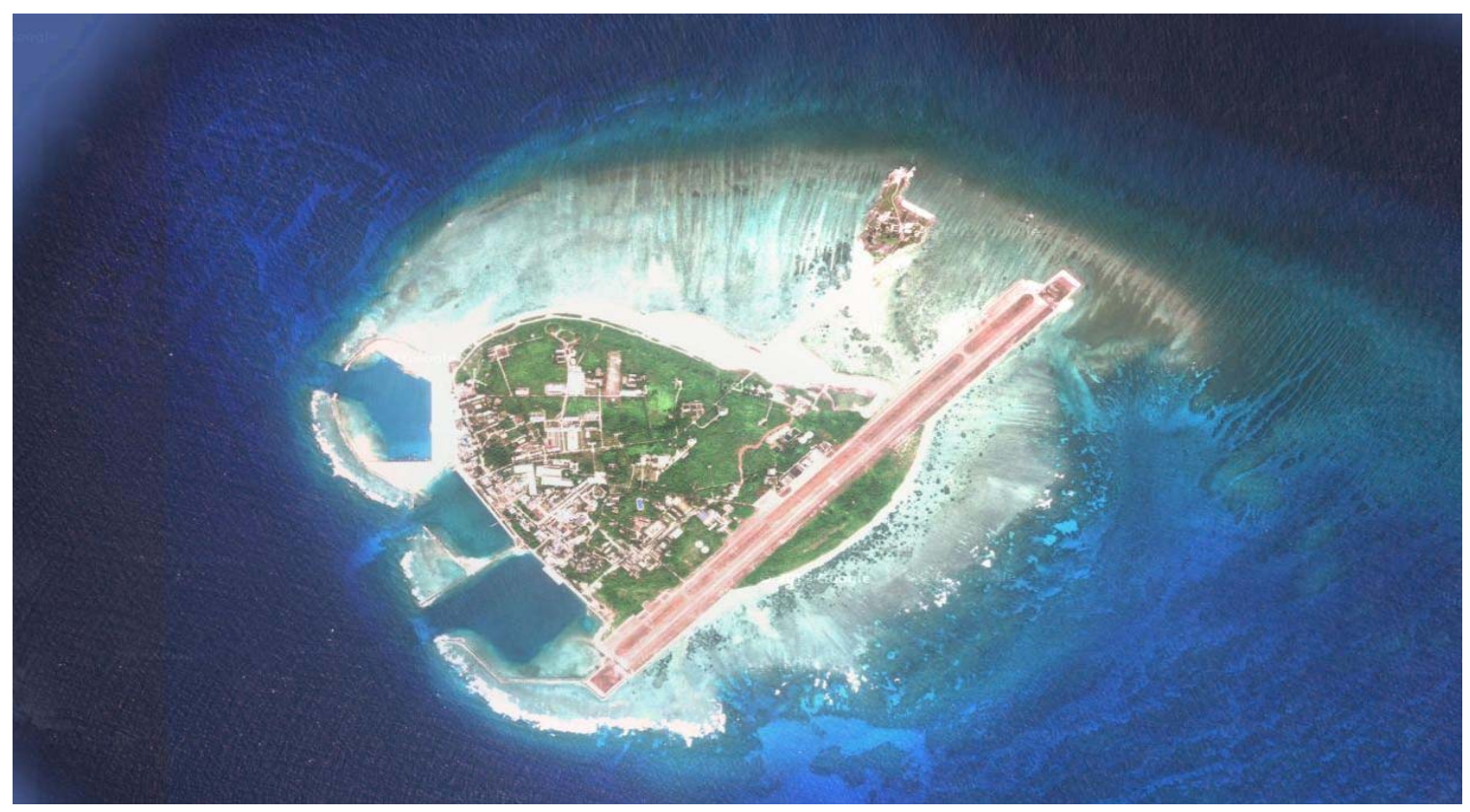

Figure 3. Woody Island. Source Google Maps

Another effort to exert control of the SCS has been the imposition of fishing bans in the area since $1999 .{ }^{133}$ These bans have been enforced by Chinese maritime agencies which habitually interdict fishing vessels from other states, particularly Vietnam and the Philippines. Some of these encounters have led to confrontations where Chinese vessels have opened fire on foreign fishermen, as was the case in March 20, 2013 when Chinese authorities fired upon Vietnamese trawlers, setting one ablaze. ${ }^{134}$ For their part the

\footnotetext{
${ }^{132}$ Ben Dolven and others, eds., "Maritime Territorial Disputes in East Asia: Issues for Congress,” Congressional Research Service, 2013, Pg. 33, http://www.fas.org/sgp/crs/row/R42930.pdf
} (Accessed September 12, 2013)

133 “China Starts Annual South China Sea Fishing Ban,” Xinhua, 2013, http://news.xinhuanet.com/english/china/2013-05/16/c_132386383.htm (Accessed September 12, 2013)

${ }^{134}$ Storey, Ian, “The South China Sea Dispute (Part 1): Negative Trends Continue in 2013,” The Jamestown Foundation China Brief 13:12 (2013), Pg. 5, http://www.jamestown.org/uploads/media/cb_06_09.pdf (Accessed, December 5, 2013) 
Philippines and Vietnam have consistently defied these bans, and in the case of the Philippines, instituted their own fishing ban to counter the Chinese. While China claims that these bans are merely efforts to replenish fish stocks in the area, neither the Philippines nor Vietnam believe that China is acting on the grounds of food security but rather to further cement its control of the SCS ${ }^{135}$

China's growing military capabilities, aided by foreign weapon acquisitions and domestic production, allow it to project power further beyond its territorial waters. Although the PRC has opted to maintain its newer and more capable military vessels away from disputed zones, its civilian maritime enforcement agencies operate former PLA Navy (PLAN) ships that are armed with guns and helicopters. ${ }^{136}$ China's principle maritime forces are:

- "China Maritime Surveillance (CMS), under the Ministry of Land and Resources;

- Fisheries Law Enforcement Command (FLEC), under the Ministry of Agriculture;

- China Coast Guard (CCG), a paramilitary People’s Armed Police (PAP) force under the Ministry of Public Security;

- Maritime Safety Administration (MSA) and China Rescue and Salvage (CRS), under the Ministry of Transportation;

- Anti-Smuggling Maritime Police, under the General Administration of Customs"137

Besides operating former PLAN vessels, these agencies are supported by aircraft and unmanned aerial vehicles (UAVs). These official vessels and aircrafts augment PLA enforcement capabilities in asserting control over the disputed areas. Analysts contend

\footnotetext{
${ }^{135}$ Hunt, Lake, “China’s Un-Neighborly Fishing Ban,” The Diplomat, 2012, http://thediplomat.com/2012/05/chinas-un-neighborly-fishing-ban/ (Accessed August 17, 2013)

${ }^{136}$ Ben Dolven and others, eds., "Maritime Territorial Disputes in East Asia: Issues for Congress," Congressional Research Service, 2013, Pg. 33, http://www.fas.org/sgp/crs/row/R42930.pdf (Accessed September 12, 2013)

${ }^{137}$ Ibid. Pg. 24
} 
that China's improved naval facilities provide China with an expanded range of coercive tools that can be deployed against rival claimants. As a result, many argue that China is pursuing a strategy of maintaining the status quo while simultaneously "strengthening actual control of the waters surrounding the disputed reefs and islands, including through official patrols in rival claimants' territorial waters." ${ }^{138}$ Its substantial submarine and subsurface vessel capabilities allow China to patrol vast stretches of disputed territory in a way that other rival claimants are unable to challenge with their current capabilities.

China has also been pursuing the purchase of longer range fighters to patrol the SCS area. The PLA's current fleet of SU-27s is only capable of conducting quick flyovers of contested territory in the SCS due to their limited internal fuel capacity, its inability to carry external fuel tanks, and the lack of external fueling capabilities. ${ }^{139}$ The fighter they are currently pursuing is the Russian-made SU-35 fighter. The SU-35 is among the best non-stealth fighters in the world and possesses a much longer effective range than its SU-27 predecessor. Its internal fuel capacity alone is 20\% greater than its predecessor. More significantly, the SU-35 can carry external fuel tanks; allowing it to loiter in contested areas for much longer periods of time. It is also important to point out that "the Su-35, would likely be able to outfly and outshoot any Philippine or Vietnamese

\footnotetext{
${ }^{138}$ Ibid. Pg. 25

${ }^{139}$ Wood, Peter, "Why China Wants the SU-35," The Jamestown Foundation China Brief, 13:20 (2013), Pg. 11-12, http://www.jamestown.org/uploads/media/China_Brief_Vol_13_Issue_20.pdf (Accessed September 12, 2013)
} 
aircraft (or surface vessel for that matter) largely rendering competing territorial claims a moot point.”140

The SCS is important to China not only because of its energy reserves or marine resources but also because it is a strategic location traversed by China's SLOC and can potentially serve as a buffer zone. A buffer zone in the SCS would allow the PLA to monitor the naval movements of potential rivals like the U.S. and Japan in the region. This would essentially help China protect the mainland more effectively, particularly the coastal regions where most of China’s industry and commerce reside. ${ }^{141}$

\section{Chapter III: Japanese Normalization}

\section{Background}

Japan has been undergoing a 'normalization' process for the past two decades. However, in order to make the claim Japan has been undergoing a process of 'normalization'; one must first address the implications of that claim. Japan is the only sovereign country in the world which has relinquished its rights to wage war or maintain armed forces. Furthermore, for a country that remains an economic powerhouse despite two decades of stagnation and sluggish recovery, Japan has been a bit player in the provision of regional and global security. ${ }^{142}$ These two points make the case for 'abnormality' because there is no precedent for either of these things being attributed to any country in history. There has been no country that has willingly given up its right to wage war; and, while the Japanese were forced to accept the current constitution after

${ }^{140}$ Ibid. Pg. 11-13

${ }^{141}$ O’Rourke, Ronald, "Maritime Territorial and Exclusive Economic Zone (EEZ) Disputes Involving China: Issues for Congress," Congressional Research Service, 2013, Pg. 14, http://www.fas.org/sgp/crs/row/R42784.pdf (Accessed September 12, 2013)

${ }^{142}$ Soeya, Yoshihida, Masayuki, Tadokoro and Welch, David A., Japan as a 'Normal Country'? (Toronto: University of Toronto Press, 2011) , Pg. 8-9 
their defeat in the aftermath of World War II, their continued adherence to Article IX is arguably self-imposed. Japan is well within its rights to amend or do away with its current constitution outright if it so desired. Additionally, there is no precedent for a country with such formidable global economic weight to not be directly engaged in providing for regional and global security. ${ }^{143}$

It does appear, however, that Japan has slowly begun to turn the corner on some of these issues. Since the aftermath of the first Gulf War, Japan has sought a more active role in peacekeeping operations around the world and has continued to expand on the roles of the JSDF. These changes are welcomed by the United States which has been actively trying to get Japan to become more engaged in regional security matters as well as to provide more capabilities for itself while the U.S. has been preoccupied with the War on Terror. Nonetheless, the movement towards ‘normalization' by Japan is seen with a wary eye by some of its neighbors, particularly China. The historical legacy between the two countries has created an atmosphere of mutual suspicion between the two countries. As a result, any move taken by Japan towards 'normalization' is perceived to be akin to remilitarization and a return to the imperial past by many Chinese officials. The source of much of the abnormality of Japan has been its pacifist constitution, more specifically Article IX.

\section{Article IX}

The main constraint on the JSDF is Article IX in the Japanese constitution. The constitution is also well known as the 'pacifist constitution' among scholars because both

\footnotetext{
${ }^{143}$ Ibid.
} 
the preamble and the famous Article IX express explicit principles of pacifism. For example, the preamble contains these passages:

"We, the Japanese people ...resolved that never again shall we be visited with the horrors of war through the action of government....

We ... desire peace for all time ... and we have determined to preserve our security and existence, trusting in the justice and faith of the peace-loving peoples of the world.”144

Following the same line of thinking, Article IX legally establishes the pacifist ideology by which Japan has operated since the constitution's adoption in 1947 through these two paragraphs:

1. Aspiring sincerely to an international peace based on justice and order, the Japanese people forever renounce war as a sovereign right of the nation and the threat or use of force as a means of settling international disputes.

2. In order to accomplish the aim of the preceding paragraph, land, sea and air forces, as well as other war potential, will never be maintained. The right of belligerency of the state will not be recognized. ${ }^{145}$

The first paragraph is interpreted to mean that while Japan renounces war as a sovereign right, it is authorized to defend itself. Most legal scholars and government officials in Japan agree with this line of thinking, although some argue that even wars of self-defense are explicitly prohibited. The second paragraph is more contentious because the majority of scholars agree that under this paragraph Japan is denied a "standing military or quasi-military force. The only ways to resist foreign aggression are through police power and an ad hoc militia (citizens with weapons)." ${ }^{146}$ Under this definition the existence of the JSDF is in clear violation of the constitution. As a result, the government

\footnotetext{
${ }^{144}$ Umeda, Sayuri, “Japan Article 9 The Constitution” Library of Congress (2006), Pg. 2, http://www.loc.gov/law/help/JapanArticle9.pdf (Accessed April 10, 2013)

${ }^{145}$ Ibid. pg. 2

${ }^{146}$ Ibid. pg. 3
} 
has opted to construe the JSDF in a different manner than the "war potential" referred to in Article IX, paragraph 2. The reasoning being that since the first paragraph does not forbid the right to self-defense, it is within the states' right to establish standing forces in order to provide for self-defense. The government believes that so long as the established forces are not greater than the minimally required for self-defense, they do not constitute "war potential”. ${ }^{147}$

It is with this in mind that the JSDF was created in 1954. Their primary purpose was to provide for the security of Japan in the event of an invasion. ${ }^{148}$ Despite their creation, however, the JSDF remained constrained by the legal ambiguity surrounding Article IX. One of the biggest points of contention arises from the fact that Article IX forbids the Japanese from participating in collective defense treaties; meaning that Japan is not allowed participate in a war even if it is to assist an ally. This is important because Japan signed a Security Treaty with the U.S. in 1951. The treaty has been revised a number of times but the essence remained the same until 1997 (which will be discussed in further detail below). The main tenets of the treaty since 1960 have been for Japan to provide the U.S with sites for the establishment of bases as well as to maintain an adequate force for self-defense (the JSDF). In return, the U.S. would provide Japan with financial assistance, military protection, and coverage under the American nuclear umbrella. ${ }^{149}$ The implication is that in the event that Japan came under attack, the United

\footnotetext{
${ }^{147}$ Ibid. pg. 4

${ }^{148}$ Ibid. pg. 14

${ }^{149}$ Hughes, Christopher W., Japan's Re-emergence as a 'Normal' Military Power, (London: Oxford University Press, 2004), Pg. 22
} 
States would have to assist Japan in the defense of their territory whereas if the U.S. came under attack, Japan would not be required to respond.

\section{The Normalization Process}

The 'normalization' of the JSDF has been a gradual process that is still ongoing. There have been a number of factors that have compelled Japan to pursue 'normalization'. These factors have been both internal and external. On the eve of the first Gulf War, Japan was asked to participate in the coalition to liberate Kuwait. The restrictions of Article IX paralyzed Japanese officials and the decision was made to simply allocate $\$ 13$ billion to fund the United Nations’ campaign in the Persian Gulf. Japanese officials were humiliated to see their country's monetary contribution, as a substitute for military support, turned into a source of contempt by other countries. ${ }^{150}$

The JSDF are prohibited by law from being deployed beyond Japanese territory. Consequently, in order for the JSDF to be dispatched outside of Japanese territory, legislation must be passed through the Diet. Immediately after the end of the Gulf War in 1992, Japan enacted the Law Concerning Cooperation for United Nations Peace Keeping Operations and Other Operations (PKO Law). This law allows for the JSDF to participate in U.N.-sanctioned peace-keeping operations albeit under serious restrictions. The JSDF troops deployed on these missions are not to be deployed in combat zones. Their role primarily revolves around providing medical care, constructing roads, and running refugee camp operations. ${ }^{151}$ The passing of this law has been noted by many to be the

\footnotetext{
${ }^{150}$ Soeya, Yoshihida, Masayuki, Tadokoro and Welch, David A., Japan as a 'Normal Country'? (Toronto: University of Toronto Press, 2011) , Pg. 44-45

${ }^{151}$ Umeda, Sayuri, “Japan Article 9 The Constitution” Library of Congress (2006), Pg. 20, http://www.loc.gov/law/help/JapanArticle9.pdf (Accessed April 10, 2013)
} 
starting point of Japan's movement towards 'normalization'. For the first time since WWII Japanese troops were being deployed overseas and participating in global security affairs. Since passing of the PKO, Japan has deployed JSDF units to "Cambodia, Mozambique, the Golan Heights, Rwanda and Honduras.”152

In 1996 Japan and the U.S. began talks on establishing new guidelines for the alliance. By 1997 the two countries had agreed to a new set of provisions which would reaffirm the bilateral defense cooperation between the two countries as well provide for breaking new ground. Of particular importance is Part V of the guidelines which calls for “Cooperation in Situations in Areas Surrounding Japan That Will Have An Important Influence on Japan's Peace And Security, stipulates details of Japan’s cooperation with the U.S. military." ${ }^{153}$ This provision is not only constitutionally problematic for Japan due to the implications that Japan may have to serve alongside the U.S. during a conflict in the region, but also for neighboring countries that see this development as potentially threatening to their interests. As mentioned above, China is especially concerned that this provision makes way for Japanese participation in a conflict between China and the U.S. over Taiwan.

Simultaneously with political movement towards 'normalization,' the Japanese public has undergone a dramatic shift throughout the 1990s in its opinion over 'normalizing' the JSDF. As a result, many support the amending of the constitution in order to make the JSDF unquestionably legal under Japanese law. For the first time since the end of WWII polls showed that nearly $60 \%$ of the Japanese population approved of

\footnotetext{
${ }^{152}$ Ibid.

${ }^{153}$ Ibid. pg. 21
} 
amending the constitution. ${ }^{154}$ This approval has been accredited to the overall satisfaction of the Japanese public with the JSDF's participation in peace-keeping operations around the world as well as more localized regional threats that they perceive. Their immediate concern has been North Korea and its nuclear and ballistic missile programs. Repeated missile tests that have violated Japanese airspace have prompted the JSDF to heavily invest in BMD. This has been a joint venture between the U.S. and Japan. The BMD program utilizes a number of platforms such as early warning radars, Aegis-equipped cruisers, and Patriot missile batteries to track and destroy incoming missile threats. ${ }^{155}$ However, while North Korea presents an immediate threat to Japan's security interests, Japanese officials agree that China will become their primary rival in the mid to longterm. China's continued military modernization and lack of defense budget transparency has provoked fear in Japan over a potential clash with China in the future. Consequently, more and more people in Japan are becoming concerned with security issues and therefore more supportive of the ongoing 'normalization' of the JSDF.

As a result of these internal and external pressures to 'normalize' the JSDF, the Ministry of Defense (MoD) was created in 2007 to replace the Japanese Defense Agency which had been founded in $1954 .{ }^{156}$ The elevation of the defense department from agency to ministry level allows for more power concentration and influence in security policies. Since the creation of the MoD, there have been active debates on lifting export bans on

\footnotetext{
${ }^{154}$ Soeya, Yoshihida, Masayuki, Tadokoro and Welch, David A., Japan as a 'Normal Country'?

(Toronto: University of Toronto Press, 2011) , pg. 48-49

155 “Japan’s BMD,” Ministry of Defense, pg. 5-6, http://www.mod.go.jp/e/d_act/bmd/bmd.pdf (Accessed April 12, 2013)

156 “About: Ministry,” Ministry of Defense, http://www.mod.go.jp/e/about/index.html (Accessed April 12, 2013)
} 
military equipment in order to provide Japanese weapons manufacturers some economies of scale when producing weapons. This would allow the Japanese military complex to remain competitive and profit from technology transfers with other developed countries. The export ban makes indigenous weapons production very costly and makes these companies increasingly unable to innovate because they cannot conduct business with foreign defense firms. ${ }^{157}$ This is a critical shortcoming for Japanese firms because other countries with developed military industrial complexes such as Japan are able to reduce costs by exporting variants of their products to other countries.

As a result, in 2011 Japan eased its export ban and set forth a new set of criteria for arms sales and production. The new criteria for transfers of defense equipment emphasize the need to cooperate with the U.S. and other countries in the development of defense equipment. It also allows for the sale of military equipment for peaceful uses on a case by case basis. Defense equipment transferred to another party cannot be used for purposes outside of the agreed framework between Japan and the recipient. Lastly, no weapons sales will be made to conflict areas where the provision of military equipment could aggravate the situation. ${ }^{158}$ This relaxation of the ban will allow Japan to participate in the production line of the Lockheed F-35 stealth fighter.

\footnotetext{
“Japan said it plans to spend some ¥1.6 trillion (\$20.8 billion) on the program over the next 20 years, and hopes to offset some of the costs of procuring and partially producing the aircraft domestically by exporting components to other F-35 buyers. The rising cost
}

\footnotetext{
${ }^{157}$ Hughes, Christopher W., Japan’s Remilitarization, (Oxon: Routledge, 2009), Pg. $72-75$

158 "Statement by the Chief Cabinet Secretary on Guidelines for Overseas Transfer of Defense Equipment etc.," Kantei, 2011, http://www.kantei.go.jp/foreign/others/201112/_icsFiles/afieldfile/2012/01/31/20111227DANW A_e.pdf (Accessed December 5, 2013)
} 
associated with producing military hardware that could technically be used only in Japan was a major factor prompting the export-ban reassessment."159

Former Prime Minister Noda approved a decision to buy 42 of the stealth fighters. Tokyo expects to win some contracts to produce components for the fighter right in Japan. It is expected that "Mitsubishi Heavy Industries Ltd., IHI Corp. and Mitsubishi Electric Corp. will participate in production of the planes, the defense ministry said.”160

Increasing public support for the amendment of the constitution has empowered legislators to pursue a draft on a number of new amendments to the constitution. These amendments would provide for the legality of the JSDF under Japanese law. Other provisions allow for the right to collective self-defense which would enable Japan to aid American troops in a combat capacity rather than simply provide rear-lines support. These changes would also allow Japan to participate in peace-keeping activities without needing new legislation every time the JSDF is deployed overseas. The draft was released in 2005 but has not been put up for a vote as of yet due to the political deadlock in the Diet. $^{161}$

Nevertheless, the pressing security issues that Japan now perceives it is facing have prompted some reforms. In 2013 Prime Minister Shinzo Abe approved legislation to create a National Security Council (NSC) based on the American system. This new body would replace the existing nine-member Security Council and provide a more centralized decision-making body composed of the prime minister, the chief cabinet secretary, the

\footnotetext{
${ }^{159}$ Dawson, Chester, “Japan Lifts Decades long Ban on Export of Weapons,” The Wall Street Journal, 2011, http://online.wsj.com/news/articles/SB10001424052970203479104577123710031180408 (Accessed December 5, 2013)

${ }^{160}$ Ibid.

${ }^{161}$ Hughes, Christopher W., Japan’s Remilitarization, (Oxon: Routledge, 2009), Pg. 118-120
} 
minister of foreign affairs, and the minister of defense. ${ }^{162 ~ " T h e ~ r e d u c e d ~ m e m b e r s h i p ~ i s ~}$ intended to facilitate prompt decision-making in national security and crisis management." ${ }^{\text {"163 }}$ Another objective of the new NSC is to make the NSC a 'headquarters' for the numerous intelligence agencies that are spread out among the different ministries. This would allow for better communication and information sharing among the different bodies and subsequently facilitate better policy making during a crisis. ${ }^{164}$ For the moment the 'normalization' of Japan has been limited to the acquisition of weapons and capabilities that push the scope of the original mission of the JSDF. In essence, Japan has been acquiring more offensive weaponry as well as power-projection capabilities. Political 'normalization' appears to be lagging behind the military establishment, although recent overtures in Southeast Asia point to a more active and engaging Japan in the political and security spheres.

\section{Capabilities of the JSDF}

Although relatively small, the JSDF maintains a level qualitative superiority exceeded only by the United States. ${ }^{165}$ With an average spending of over $\$ 50$ billion annually, Japan ranks fifth in the world in total military spending; surpassed by the United States, China, Russia and the United Kingdom. ${ }^{166}$ These figures indicate that

\footnotetext{
${ }^{162}$ Takahashi, Toshiya, “Abe and a Japanese National Security Council,” East Asia Forum, 2013, http://www.eastasiaforum.org/2013/07/16/abe-and-a-japanese-national-security-council/ (Accessed December 12, 2013)

${ }^{163}$ Ibid.

${ }^{164}$ Ibid.

${ }^{165}$ Soeya, Yoshihida, Masayuki, Tadokoro and Welch, David A., Japan as a 'Normal Country'? (Toronto: University of Toronto Press, 2011) , Pg. 21

166 “SIPRI Military Expenditure Database”, Stockholm International Peace Research Institute,(2012),
} 
despite having a pacifist constitution, Japan has been able to develop one of the most powerful military forces in the world. Consistent with the 'normalization' process, the JSDF has been acquiring weapon systems that go beyond the scope of self-defense and into the area of power-projection capabilities. Every service appears to be moving forwards with acquisitions that make power projection a reality for Japan.

\section{Ground Forces}

For its part "the Ground Self-Defense Forces (GSDF) established a Central Readiness Group (CRG) in 2007, combining the elite $1^{\text {st }}$ Airborne Brigade, $1^{\text {st }}$ Helicopter Brigade, $101^{\text {st }}$ Nuclear, Biological and Chemical (NBC) Unit and the Special Operations Group (SOG)." ${ }^{167}$ The CRG serves as a rapid-reaction force which allows Japan to react immediately in the event of a terrorist attack or other internal crises. These forces are also responsible for training troops headed for overseas deployment. ${ }^{168}$ This indicates that Japan is progressively enhancing its capability to deploy forces overseas at a moment's notice in the same manner that other modern powers are equipped to do. This capability enhances Japan’s power-projection capabilities significantly as most militaries in the world, with the exception of modern western forces, are not equipped to deploy overseas at a moment's notice in the event that a crisis occurs.

The JSDF is also creating amphibious capabilities in the form of the Amphibious Preparatory Unit (APU). The MoD budget for 2014 states that in order to

\footnotetext{
http://www.sipri.org/research/armaments/milex/research/armaments/milex/research/armaments/mi lex/milex_database (Accessed April 11, 2013)

${ }^{167}$ Hughes, Christopher W., Japan’s Remilitarization, (Oxon: Routledge, 2009), Pg. 41

${ }^{168}$ Ibid.
} 
"effectively respond to attacks on remote islets, air superiority and command of the sea must be maintained. To rapidly deploy troops as the situation unfolds, mobile deployment capability and amphibious capability are also important. To steadily build-up such mobile deployment capability, consideration of the optimal deployment posture of troops and equipment, joint transport, utilizing civilian transport capacity, creating supply bases, and properly equipping the new amphibious unit for the amphibious mission are important." 169

Although not explicitly named in the report, the MoD is clearly referring to the Senkaku/Diaoyu Islands where continued Chinese naval and aerial incursions have become increasingly common. The 700-man APU will be formed out of the GSDF. Japan's MoD states that the unit will eventually reach a total of 3000 soldiers. This unit will be based out of Sasebo, Nagasaki Prefecture in southern Japan. ${ }^{170}$ The APU could be supplemented with the acquisition of the V-22 Osprey tilt-rotor aircraft that the U.S. Marines currently operate. ${ }^{171}$ The acquisition of the Osprey would enhance mobility and speed of the GSDF in the event that it has to respond to a physical Chinese incursion in the Senkaku/Diaoyu islands.

\section{Naval Forces}

The Maritime Self-Defense Forces (MSDF) has engaged in the production of vessels which clearly enhance Japan's power-projection capabilities. The first of these vessels is the Osumi-class landing ship tanks (LSTs) (See Figure 4). These ships have a flat-top deck which allows it to operate a contingent of helicopters to assist in landing operations. The ship carries Landing Craft Air Cushion-class hovercraft (LCAC) which

\footnotetext{
169 "Defense Programs and Budget of Japan: Overview of FY 2014 Budget Request,” Ministry of Defense, 2013, Pg. 8 http://www.mod.go.jp/e/d_budget/pdf/251009.pdf (Accessed December 13, 2013)

${ }^{170}$ Sonoda, Koji, “Japan’s New Defense Guidelines Stipulate Amphibious Force,” The Asahi Shimbun, 2013, http://ajw.asahi.com/article/behind_news/politics/AJ201310120038 (Accessed December 13, 2013)

171 "Defense Programs and Budget of Japan: Overview of FY 2014 Budget Request," Ministry of Defense, 2013, Pg. 10 http://www.mod.go.jp/e/d_budget/pdf/251009.pdf (Accessed December 13, 2013)
} 
can be used to ferry troops to shore as well as tanks and other armored vehicles. These ships saw action in 1999 and 2003 when they were deployed to East Timor and Iraq respectively. ${ }^{172}$ The second ship class is the Hyuga-class helicopter destroyer. These ships are classified as helicopter destroyers because, like the Osumi-class ships, they have a flat-top deck to accommodate helicopters (See Figure 5). Unlike the Osumi, however, the Hyuga has sub-deck hangars to store a larger contingent of aircraft. Many have speculated that the ship is capable of launching vertical/short take-off and landing (VSTOL) aircraft with minor modifications thus making it an aircraft carrier, an offensive weapon which Japan is not legally allowed to operate under Article IX due to the capabilities provided by such a vessel. The MSDF currently operates two of these ships and plans to acquire two larger vessels. ${ }^{173}$

The first of this new class was unveiled in august 2013 and has been classified as the Izumo-class helicopter destroyer (22DDH) (See Figure 6).

"At 250 meters (820 feet) long, and reportedly displacing 24,000 tons, the ship can carry 14 helicopters. It is the largest warship Japan has fielded since WWII, and about 50 percent bigger (in terms of displacement) than Japan's current largest ship, the Hyugaclass helicopter destroyer.",174

Its primary mission will be anti-submarine warfare, surveillance, and to transport personnel. ${ }^{175}$ The unveiling sparked intense debate within China where the Chinese Defense Ministry stated that: "We are concerned over Japan's constant expansion of its

\footnotetext{
${ }^{172}$ Hughes, Christopher W., Japan's Re-emergence as a 'Normal' Military Power, (London: Oxford University Press, 2004), Pg. 79 \& 82

173 “JMSDF Hyuga Class Destroyer, Japan,” Naval-Technology.com, http://www.naval-technology.com/projects/hyuga-class/ (Accessed April 12, 2013)

${ }^{174}$ Keck, Zachary, “Japan’s Unveils “Aircraft Carrier in Disguise,”” The Diplomat, 2013, http://thediplomat.com/2013/08/japans-unveils-aircraft-carrier-in-disguise/ (Accessed September 26, 2013)

175 Ibid.
} 
military equipment. Japan's Asian neighbors and the international community need to be highly vigilant about this trend." ${ }^{176}$ Li Daguang, a professor as China’s National Defense University of the People's Liberation Army, stated that the Izumo was essentially a "carrier in disguise," noting that "Japan tops the world in terms of its anti-submarine capability and the warship would further consolidate its advantage."177

Classifying this ship as a destroyer is purely a matter of bypassing the legality of operating an aircraft carrier. Should this ship operate a variant of the F-35 fighter it would automatically make this ship an aircraft carrier. The V-22 Osprey alone would be enough to reclassify this ship since the Osprey flies like a normal aircraft once it has taken off. The F-35 and V-22 would allow this ship to operate beyond the role of anti-submarine warfare it was originally intended for. ${ }^{178}$ Izumo-class ships significantly increase Japan’s naval power by providing it with real power-projection capabilities.

Japan's powerful naval capabilities can easily complement the new APU. It already possesses key elements for amphibious operations, notably the three Osumi-class LSTs and the LCAC hovercrafts. Additionally, the MSDF can deploy the Hyuga and Izumo helicopter destroyers to provide airlift during operations. ${ }^{179}$ The MoD is also

\footnotetext{
${ }^{176}$ Zhaokun, Wang, “Tokyo Unveils New Carrier,” Global Times, 2013, http://www.globaltimes.cn/content/802056.shtml\#.UuhERPnTmUl (Accessed September 26, 2013) ${ }^{177}$ Ibid.

${ }^{178}$ Keck, Zachary, “Japan’s Unveils “Aircraft Carrier in Disguise,”” The Diplomat, 2013, http://thediplomat.com/2013/08/japans-unveils-aircraft-carrier-in-disguise/ (Accessed September 26, 2013)

${ }^{179}$ Moss, Trefor, “Japan’s New (Defensive) Attack Force,” The Diplomat, 2013, http://thediplomat.com/2013/11/japans-new-defensive-attack-force/?allpages=yes (Accessed September 26, 2013)
} 
taking steps to strengthen command functions during amphibious operations by installing conference equipment on the Izumo destroyers. ${ }^{180}$

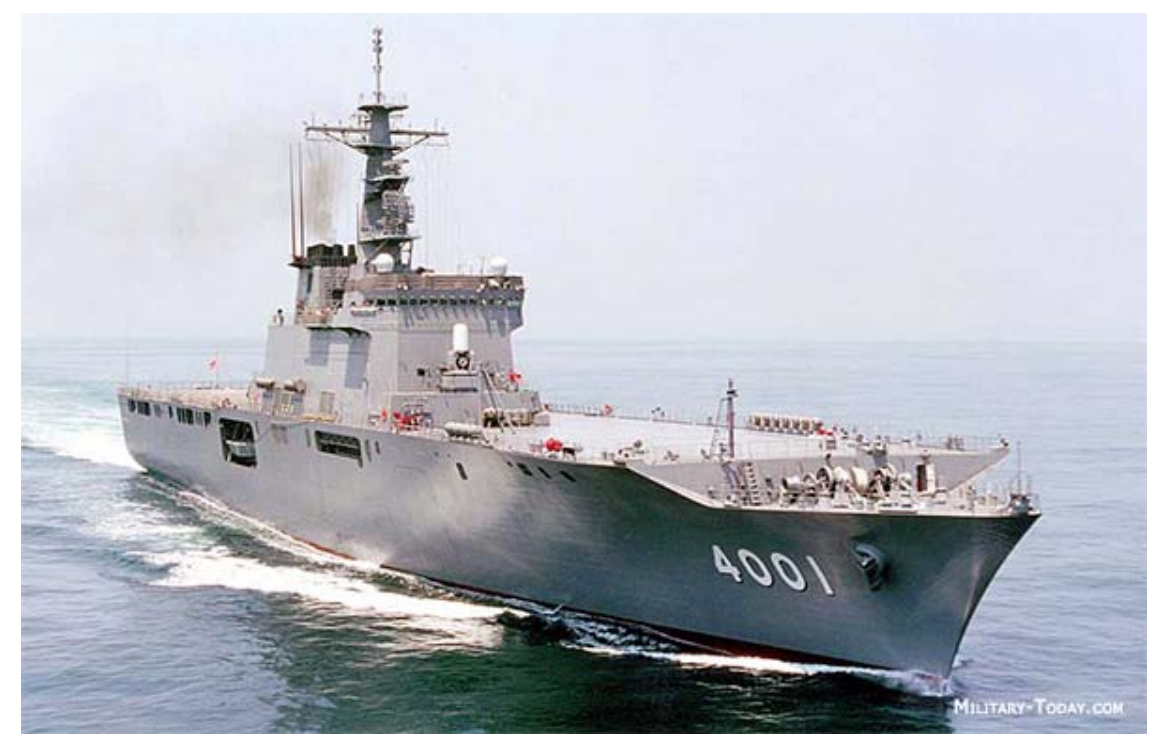

Figure 4. Osumi-Class LST. Source Military-Today.com: http://www.military-today.com/navy/oosumi_class.htm

180180 “Defense Programs and Budget of Japan: Overview of FY 2014 Budget Request,” Ministry of Defense, 2013, Pg. 9,

http://www.mod.go.jp/e/d_budget/pdf/251009.pdf (Accessed December 13, 2013) 


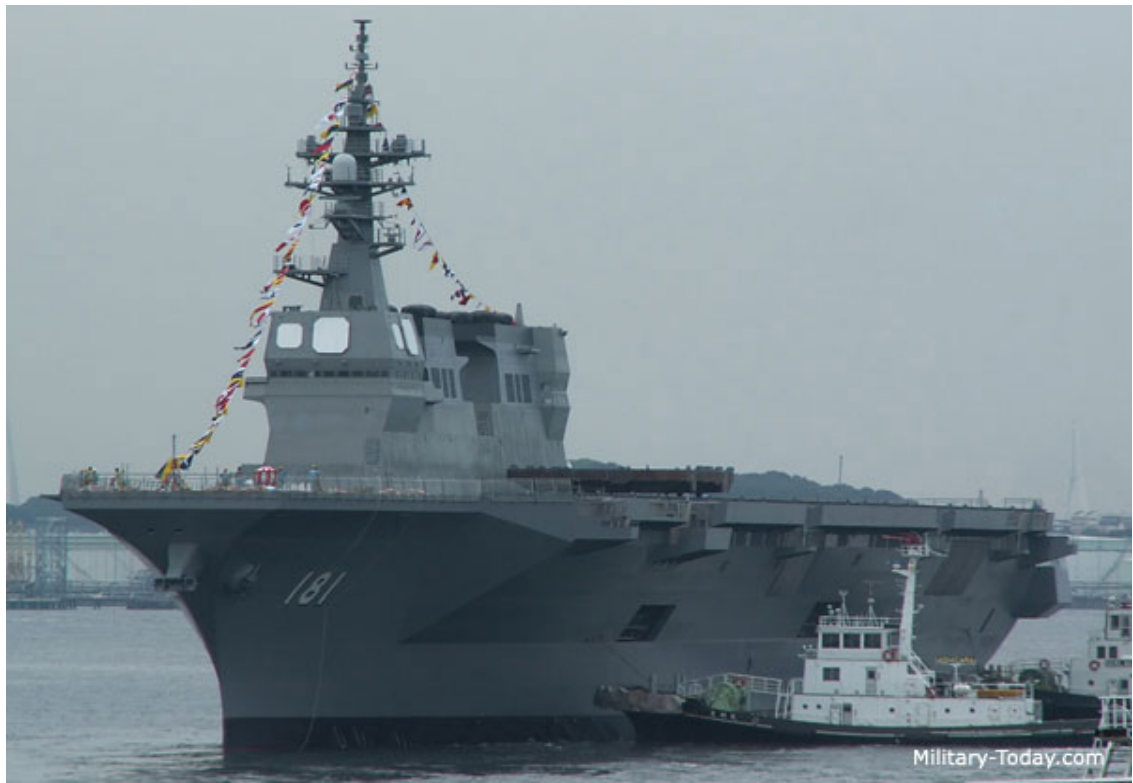

Figure 5. Hyuga-Class Helicopter Destroyer. Source Military-Today.com: http://www.military-today.com/navy/hyuga_class.htm

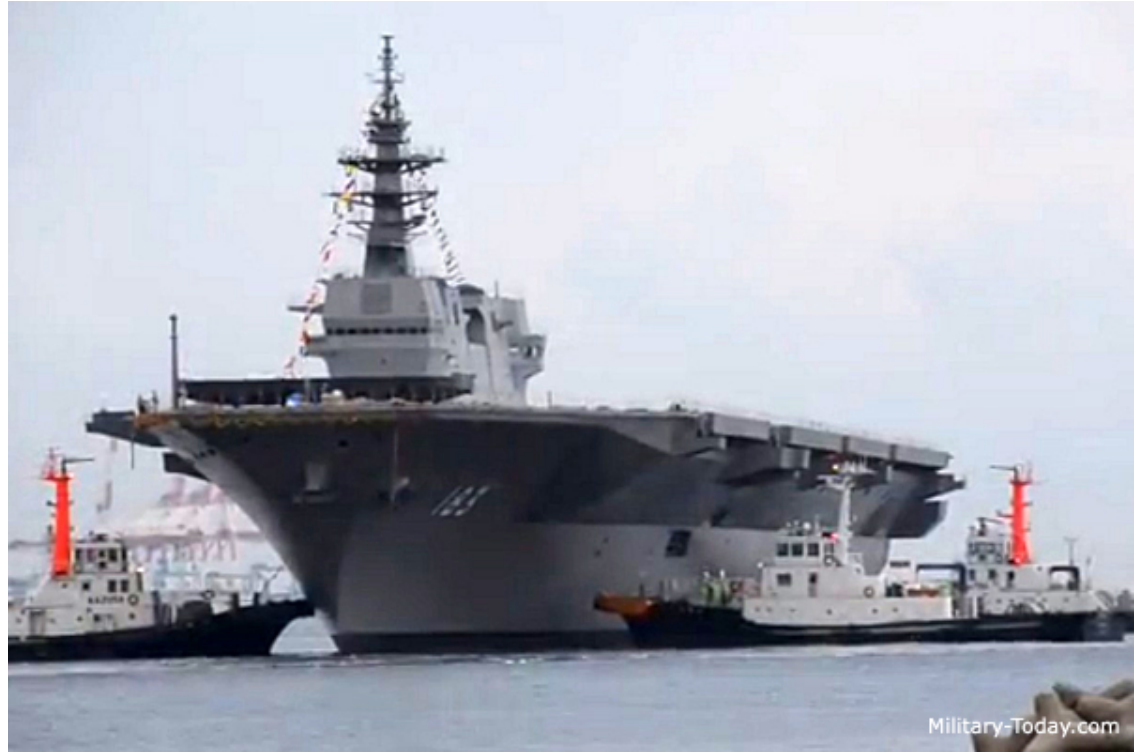

Figure 6. Izumo-Class Helicopter Destroyer. Source Military-Today.com: http://www.military-today.com/navy/izumo_class.htm 


\section{$\underline{\text { Air Forces }}$}

The Air Self-Defense Forces (ASDF) has also been keen on expanding their role and providing for more power-projection capabilities by acquiring tanker aircraft. The ASDF currently operates four Boeing 767 tankers and plans to double that capacity in coming years. Tanker aircraft provide the capability to perform in-flight refueling and therefore increase the range of fighter planes and interceptors. While the legal rationale for acquiring these tankers has been to provide for more efficient use of pilot time and allow aircraft to remain airborne during poor weather conditions which make landing difficult, it is clear that having in-flight refueling capabilities increases the ASDF's

offensive and power-projection potential. ${ }^{181}$ Not many countries have the expertise to operate in-flight refueling operations; this makes Japan’s ability to do so an important step towards 'normalizing' the JSDF.

These are but a number of the many acquisitions that Japan has been making as it continues to push for further 'normalization' of its forces. Each branch has continued to maintain a qualitative superiority to their regional competitors as current conditions do not allow for increased quantitative capabilities. These programs not only allow Japan to more efficiently participate in global crisis situations but also allow it to maintain a certain level of expertise in its defense industry.

\section{Japan's South China Sea Policy}

The ‘normalization’ process currently underway in Japan has a number of security implications, particularly in regards to the ECS and the SCS. The increase in power-

\footnotetext{
${ }^{181}$ Hughes, Christopher W., Japan's Re-emergence as a 'Normal' Military Power, (London: Oxford University Press, 2004), Pg. 83
} 
projection capabilities by the JSDF is alarming for many Chinese officials who contend that Japan is working with the U.S. on a containment strategy against China. They validate this belief by pointing to the revised guidelines of 1997 in which Japan could assist the U.S. in security matters in the region. The fact that Japan has refused to rule out involvement in a Taiwanese contingency unnerves Chinese officials. ${ }^{182}$ There continues to be a sense of mutual suspicion on both sides which makes positive security relations between them extremely difficult.

However, among Southeast Asian countries, Japan’s increasing willingness to challenge China on the ECS has been a welcome development. The Philippine Foreign Affairs secretary stated that his "country would welcome a rearmed Japan as a balancing factor in the region." ${ }^{, 183}$ The Minister’s statement reveals that despite the fact that Japan led a brutal occupation of the Philippines during WWII, China's increasingly assertive posture in the region has changed the political calculations of the country. The Vietnamese have also been active in strengthening ties with Japan in order to counter China. Nguyen Tan Dung, the Vietnamese Defense Minister, stated that "The relationship between the two countries is extremely important."184

\footnotetext{
${ }^{182}$ Roy, Denny, “Stirring Samurai, Disapproving Dragon: Japan’s Growing Security Activity and SinoJapan Relations," Asia-Pacific Center for Security Studies, 2003, Pg. 97, http://www.jstor.org/discover/10.2307/30172610?uid=3739256\&uid=2129\&uid=2\&uid=70\&uid= 4\&sid=21101516703917 (Accessed November 5, 2012)

${ }^{183}$ Sasahara, Koji, “Philippines Backs Rearming Japan,” CNBC Asia-Pacific News, 2012, http://www.cnbc.com/id/100293527 (Accessed, October 12, 2013)

${ }^{184}$ Kurashige, Nanae, “Japan, Vietnam Agree on Defense Cooperation,” The Asahi Shimbun, 2011, http://ajw.asahi.com/article/behind_news/politics/aj2011102515718 (Accessed October 13, 2013)
} 
For its part Japan has been active in Southeast Asia, particularly in the provision of training and hardware to regional coastguards. ${ }^{185}$ "The Japan International Cooperation Agency (JICA) funds the Coast Guard's seminars to train maritime authorities in Southeast Asia, and Japan's aid is critical in helping to create maritime patrol authority where local capacity is lacking." ${ }^{\prime 186}$ This is especially true in the case of the Philippines. The purpose of this aid has been to strengthen the maritime capabilities of the SCS littoral countries in order to improve the safety of the SCS due to the chronic issues of piracy that plague the area. To that end, Japan provided the seed money for the AntiPiracy Center located in Kuala Lumpur in Malaysia. ${ }^{187}$ Japan has also been providing coastguard ships to countries in the SCS region. In 2006 Japan gave Indonesia 3 patrol vessels. ${ }^{188}$ Tokyo also has plans to provide the Philippines and Vietnam with a number of coast guard ships in the near future. (This will be discussed further below).

Besides promoting maritime safety in the SCS, Japan has begun to participate in a number of naval exercises in the area. In 2011 Japan joined the United States and Australia in a SCS drill. The MSDF sent a destroyer to join ships from the other two navies off the coast of Brunei. These drills incorporated communications training and other measures. In a statement the MoD said that "The exercise is aimed at enhancing

\footnotetext{
${ }^{185}$ Kang, Harnit, "Maritime Issues in South China Sea: A Survey of the Literature," Institute of Peace and Conflict Studies, 2009, Pg. 5, http://www.ipcs.org/pdf_file/issue/SR76-Harneet-Final.pdf (Accessed, October 13, 2013)

${ }^{186}$ Sato, Yoichiro, “ Southeast Asian Receptiveness to Japanese Maritime Security Cooperation,” Asia-Pacific Center for Security Studies, 2007, http://www.apcss.org/Publications/Maritime\%20security\%20cooperation\%20JapanSE\%20Asia\%20Sato.pdf (Accessed, October 12, 2013)

${ }^{187}$ Ibid.

${ }^{188}$ Ibid.
} 
tactical skills of the Maritime Self-Defense Force and strengthening relations with the participating navies. ${ }^{189}$ In a more recent development, the U.S. and the Philippines have considered inviting Japan to the annual U.S.-Philippine Balikatan exercises. These exercises focus on humanitarian relief as well as traditional military training and help provide better coordination between the two allies. Philippine Army Major General Virgilio Domingo, who was the director of the 2013 Balikatan exercises, said that the expansion of the joint military drills into a "multilateral military engagement will be beneficial to troops of participating countries."190

All of these measures are indicative that as Japan 'normalizes' it will seek a larger stake in regional security. This will be matched by a more assertive China as a result of its growing economic and military clout. If mutual suspicion continues to plague the security relations between these two powers, the probability for heightened tensions and possible clashes will be high in the ECS and the SCS. It is clear that Japan has been more willing to confront what it perceives as Chinese incursions into its territory around the Senkaku/Diaoyu Islands. It is also clear that Japan perceives China's increasingly assertive activities in the SCS as detrimental to its national interests. These developments have prompted Japan to seek a more prominent political and security role in Southeast Asia in order to balance China.

\footnotetext{
${ }^{189}$ US, Japan, Australia Plan South China Sea Drill,” Associated Free Press, 2011, http://www.google.com/hostednews/afp/article/ALeqM5ijF5kpgjM_4UmJeWA05Yu1sfKtg?docId=CNG.b25e50471bf7cd80f49ff0b9169e31d7.121 (Accessed October 5, 2013)

190 “Philippines, U.S. Eye Expansion of Joint Military Exercise,” Xinhua, 2013, http://news.xinhuanet.com/english/world/2013-04/17/c_132317138.htm (Accessed, October 5, 2013)
} 


\section{Chapter IV: Republic of the Philippines Case Study}

\section{Background}

Located on the east end of the SCS, the Philippines is among the claimants to a number of features on the Spratly Island group. The Philippines had been a colony of the Spanish Empire from the $16^{\text {th }}$ century until 1898 when control of the island was ceded to the United States after the Spanish lost the Spanish-American War. In 1942 the islands fell under Japanese control as Japan was expanding its empire through Southeast Asia. It would not be until 1946 that the Republic of the Philippines acquired its independence from the United States. ${ }^{191}$ Almost immediately the Philippines became an active claimant in the SCS.

The Philippines lays claim to 53 islands, islets, reefs, shoals, cays, rocks, and atolls with an area of 64,976 square miles; the largest of these is called Thitu Island. Collectively these features are known as the KIG by the Philippines. ${ }^{192}$ At the moment the Philippines controls 7 islands and 3 reefs in the Spratly Island group. These are:

(Philippine name/International name)

1. Kota or Loaita Island

2. Lawak or Nansham Island

3. Likas or West York Island

4. Panata or Lamkian Cay

5. Pag-asa or Thitu Island

6. Parola or North East Cay

7. Patag or Flat Island

8. Rizal or Commodore Reef

9. Balagtas Reef or Irvin Reef

\footnotetext{
191 “The Philippines,” CIA World Factbook, https://www.cia.gov/library/publications/the-world-factbook/geos/rp.html (Accessed December 12, 2013)

${ }^{192}$ Banlaoi, Rommel C., Philippines-China Security Relations: Current Issues and Emerging Concerns (Quezon City: Philippine Institute for Peace, Violence and Terrorism Research, 2012), Pg. 23
} 


\section{Ayungin Reef or Second Thomas Shoal ${ }^{193}$}

As mentioned above, the most significant island occupied by the Philippines is Pag-asa or Thitu Island, as it is internationally known. The island houses a naval detachment as well as a runway that is maintained by the $570^{\text {th }}$ Composite Tactical Wing of the Philippine Air Force (PAF). Pag-asa is also the only SCS feature occupied by the Philippines that has civilian residents, with at least five families residing on the island. Here lies the main seat of the Municipality of Kalaya'an. Besides the military structures, the island also has sports facilities, a municipal hall, a village hall, and a police station (See Figure 7). ${ }^{194}$

The SCS is of significant strategic importance to the Philippines for a number of reasons, particularly its energy and marine resources as well as its strategic location as a main artery of trade. Together, these reasons provide justification for the Philippines' active diplomatic and military policy in the region.

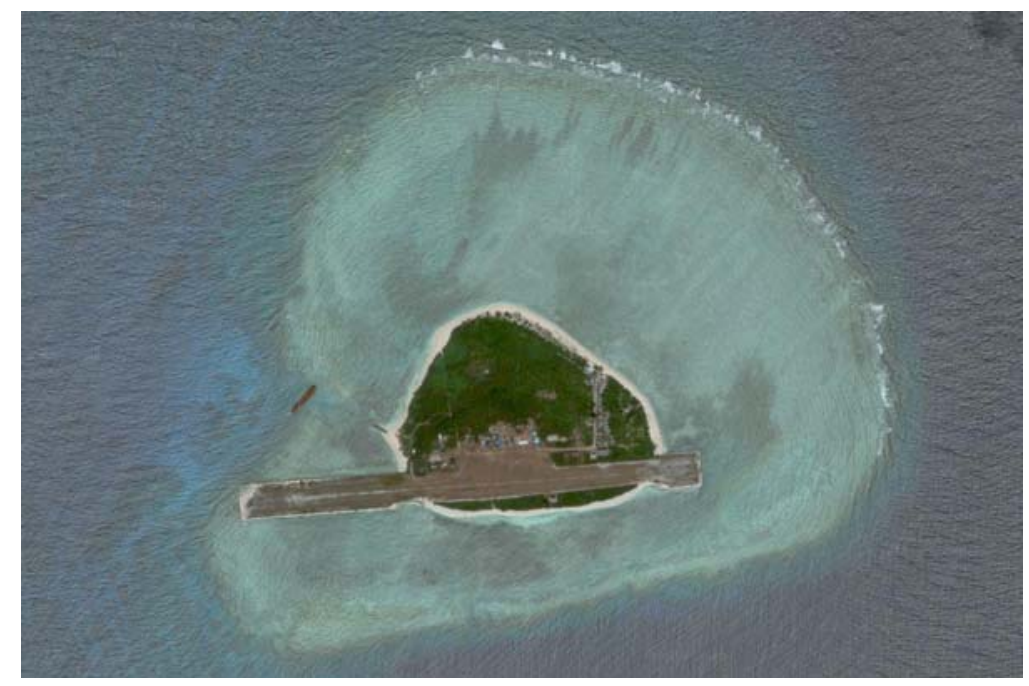

Figure 7: Thitu Island. Source Google Maps

\footnotetext{
193 "Digital Gazetteer of the Spratly Islands," The South China Sea, http://www.southchinasea.org/2011/08/19/digital-gazetteer-of-the-spratly-islands/ (Accessed December 12, 2013)

${ }^{194}$ Banlaoi, Rommel C., Philippines-China Security Relations: Current Issues and Emerging Concerns (Quezon City: Philippine Institute for Peace, Violence and Terrorism Research, 2012), Pg. 62
} 


\section{Energy Resources}

The International Energy Agency (IEA) stated that the Philippines annual energy needs in 2007 was 40 million tons of oil; a figure that is expected to grow at an average of 2.8\% annually until 2030. In 2010 oil accounted for nearly 35\% of the Philippines’ energy consumption. This percentage translates to 282,000 barrels per day (bpd). ${ }^{195}$ Considering the fact that the Philippines' own domestic production of oil is roughly 23,000 bpd, coupled with the fact that its own domestic policy towards its Muslim population has led to tensions with the Arab world and Indonesia, Philippine energy security is questionable. As a result, the Philippines finds itself in great need of raising the production of its own fields in Malampay and Palawan, both of which are located in the SCS. ${ }^{196}$ Furthermore, the Philippines hopes to exploit the resources in Reed Bank which is said to have significant oil and natural gas deposits. However, in order to achieve this, it must maintain control of the Second Thomas Shoal which serves as a strategic gateway to Reed Bank. The Second Thomas Shoal is home to about 10 Philippine marines who are based on a World War II-era ship that was intentionally grounded on the shoal. This strategic location has come under direct Chinese pressure in recent years as Chinese surveillance ships have attempted to block Philippine vessels attempting to resupply the marines. ${ }^{197}$

\footnotetext{
${ }^{195}$ Hong, Zhao, “China-Philippines Relations Stunted by South China Sea Dispute,” Institute of Southeast Asian Studies SEAS Perspective 17 (2013), Pg. 2, http://www.iseas.edu.sg/documents/publication/ISEAS\%20Perspective\%202013_17.pdf (Accessed November 11, 2013)

196 Ibid. Pg. 2-3

${ }^{197}$ Bonnie Glaser and Alison Szalwinski, "Second Thomas Shoal Likely the Next Flashpoint in South China Sea,” The Jamestown Foundation China Brief 13:13 (2013), Pg. 5-6, http://www.jamestown.org/uploads/media/cb_06_21.pdf (Accessed December 5, 2013)
} 


\section{Marine Resources}

Exploitation of marine resources in the SCS is also of vital importance to the Philippine state due to its heavy reliance on fishing both for consumption and as a source of income. According to a study performed by the Philippine Department of Agriculture: Bureau of Fisheries and Aquatic Resources (DA-BFAR), commercial and municipal fishing brought in catches valued 67.4 billion Philippine Pesos ( $\$ 1.4$ billion) in 2001. Exports of tuna, crab and octopus were valued at 10.7 billion Philippine Pesos ( $\$ 237$ million) in the same year. ${ }^{198}$ By 2011 fishery exports were valued at $\$ 871$ million. ${ }^{199}$ The DA-BFAR report goes on to state that fish are considered a staple food in the Philippine diet, contributing $12.3 \%$ of the total food consumption of Filipinos annually. Fish contributes $22.4 \%$ of the total protein intake of the average Filipino and is $56 \%$ of the animal protein consumed in the Philippines yearly. ${ }^{200}$ This report is indicative of the fact that access to marine resources in the SCS is vital to the food security and economic wellbeing of the Philippines.

\section{Strategic Value}

The Philippines also has strategic interests in the region which are motivated by two factors: freedom of navigation and international awareness. Since the Philippines is one of the only two archipelagic states in the region, the second being Indonesia, it is heavily dependent on the freedom of navigation in the SCS. The country has a total

\footnotetext{
${ }^{198}$ Cesar Z. Luna and others eds., "Profiling the Status of Philippine Marine Fisheries: A General Introduction and Overview," in In Turbulent Seas: The Status of Philippine Marine Fisheries (Manilla: Department of Agriculture: Bureau of Fisheries and Aquatic Resources, 2004), Pg. 3

199 "Fish Contribution to the Economy," Bureau of Fisheries and Aquatic Resources, http://www.bfar.da.gov.ph/pages/AboutUs/maintabs/stat-fishcontri_2011.html (Accessed December 5, 2013)

${ }^{200}$ Espejo-Hermes, Jasmin, “Trends and Status of Fish Processing Technology,” in In Turbulent Seas: The Status of Philippine Marine Fisheries (Manilla: Department of Agriculture: Bureau of Fisheries and Aquatic Resources, 2004), Pg. 122
} 
coastline measuring $17,500 \mathrm{~km}$, of which 1,200 face directly towards the SCS. ${ }^{201}$ Furthermore, over 41,000 ships pass through the SCS annually, making the SLOC vital to the economic wellbeing of the country. ${ }^{202}$ This is highlighted by the fact that roughly 20,000 commercial vessels navigate Philippine waters annually. ${ }^{203}$ The second factor is directly linked to the Philippine territorial claims in the SCS. This is due to the fact that:

"shippers and mariners do not use the Philippine sea lanes as extensively as the Strait of Malacca and the South China because voyages in the Philippine waters will take longer. Thus, the Philippines has to pursue its claims in the busy waterways of the Spratlys to promote its navigational rights.",204

This has inevitably led to more direct confrontations with China in the SCS.

\section{Sino-Philippine Disputes}

The security relation between China and the Philippines has come to be dominated by the competing territorial claims they have in the Spratly Islands. These disputes escalated dramatically in 1995 when the Armed Forces of the Philippines (AFP) discovered that the PLA had occupied Mischief Reef and had erected wooden structures on the reef. ${ }^{205}$ This would be the China's first major occupation in the SCS since its eviction of Vietnam from the Paracels during Cold War. ${ }^{206}$ This bold move by China was

\footnotetext{
${ }^{201}$ Banlaoi, Rommel C., Philippines-China Security Relations: Current Issues and Emerging Concerns (Quezon City: Philippine Institute for Peace, Violence and Terrorism Research, 2012), Pg. 27

${ }^{202}$ Khemakorn, Pakjuta, "Sustainable Management of Pelagic Fisheries in the South China Sea Region,” United Nations - The Nippon Foundation, 2006, Pg. 14, http://www.un.org/depts/los/nippon/unnff_programme_home/fellows_pages/fellows_papers/khem akorn_0607_thailand.pdf (Accessed November 12, 2013)

${ }^{203}$ Banlaoi, Rommel C., Philippines-China Security Relations: Current Issues and Emerging Concerns (Quezon City: Philippine Institute for Peace, Violence and Terrorism Research, 2012), Pg. 27

${ }^{204}$ Ibid.

${ }^{205}$ Storey, Ian, Southeast Asia and the Rise of China: The Search for Security (New York: Routledge, 2011), Pg. 255

${ }^{206}$ Emmers, Ralf, Geopolitics and Maritime Territorial Disputes in East Asia
} 
facilitated by the fact that the after the Cold War ended, the U.S. and the Philippines could not agree on negotiations over the future of American military bases in the country. As a result, by 1992 the last American "service personnel had been withdrawn from the Philippines."207 This essentially reinforces Buzan and Waever's assertion that the end of the Cold War provided China with more freedom of action. ${ }^{208}$ Coupled with the withdrawal of U.S. troops from the Philippines and American statements of neutrality regarding the SCS issue, emboldened the Chinese to take action.

These events led the Philippine government to believe that despite the sympathy it received from other countries regarding the confrontation in Mischief Reef, the issue would remain a bilateral problem. ${ }^{209}$ Repeated confrontations would occur throughout the 1990s placing further strain on Sino-Philippine relations. There would be a relatively quiet period during the early 2000s as a result of China's “charm offensive.” However, by 2009 the number of confrontations would flare up creating heightened tensions in the region once again. ${ }^{210}$ The most significant of the most recent clashes has been over the Scarborough Shoal; an area which both countries claim.

The incident began in April 2012 when a Philippine surveillance aircraft spotted five Chinese vessels in the lagoon of the shoal. Upon dispatching a naval ship to

\footnotetext{
(New York: Routledge, 2010), Pg. 71

${ }^{207}$ Storey, Ian, Southeast Asia and the Rise of China: The Search for Security

(New York: Routledge, 2011), Pg. 255

${ }^{208}$ Barry Buzan and Ole Waever, Regions and powers: The Structure of International Security (Cambridge: Cambridge University Press, 2003), Pg. 144

${ }^{209}$ Emmers, Ralf, Geopolitics and Maritime Territorial Disputes in East Asia (New York: Routledge, 2010), Pg. 72

210 "Flashpoints: Security in East and South China Seas," Center for New American Security, http://www.cnas.org/flashpoints/timeline (Accessed December 5, 2013)
} 
investigate the Chinese vessels, the Philippine claimed that the fishermen were poaching "species protected under Philippines law and the Convention on International Trade in Endangered Species of Wild Flora and Fauna."211 Two Chinese surveillance vessels soon arrived at the site and interposed themselves between the Philippine frigate and the fishing vessels. Both countries have protested each other's actions although the Philippines was first to withdraw from the area. ${ }^{212}$ In the aftermath China has maintained a number of vessels in the area, although it has not interfered with Philippine fishing boats operating in and around the shoal. ${ }^{213}$

\section{The West Philippine Sea}

Heightened tensions over the SCS disputes have seen the rise of nationalism in both China and the Philippines. Each side taking unilateral measures to counter the other in the form of fishing bans, as discussed above, or by renaming the area as the Philippines has recently done. Through Administrative Order No. 29, Philippine President Benigno Aquino III has renamed the SCS as the "West Philippine Sea." ${ }^{214}$ President Aquino stated that the Philippines has the "inherent power and right to designate its maritime areas."215

Despite Chinese protestations that the move violates the international standardization of

${ }^{211}$ Thayer, Carlyle A., "Standoff in the South China Sea," YaleGlobal, 2012, 212 Ibid. http://yaleglobal.yale.edu/content/standoff-south-china-sea (Accessed December 5, 2013)

${ }^{213}$ Romero, Alexis, "Pinoy Fishermen Defy New Chinese Fishing Rules in Panatag Shoal," The Philippine Star, 2014, http://www.philstar.com/headlines/2014/01/26/1283092/pinoyfishermen-defy-new-chinese-fishing-rules-panatag-shoal (Accessed February 2, 2014)

${ }^{214}$ Blanco Pitlo III, Lucio, “The Philippines and the West Philippine Sea,” The Diplomat, 2013, http://thediplomat.com/2013/10/the-philippines-and-the-west-philippine-sea/ (Accessed December 10, 2013)

${ }^{215}$ Magdaraog Cordero, Jean, “Manila Formalizes ‘West Philippine Sea’ Name,” Asia-Pacific Defense Forum, 2012, http://apdforum.com/en_GB/article/rmiap/articles/online/features/2012/10/24/philippines-seaname (Accessed December 10, 2013) 
geographic names, and that the name South China Sea is internationally recognized even by the Philippines, Aquino directed the National Mapping and Resource Information Authority (NAMRIA) to begin producing maps and charts of the Philippines reflecting the name change. ${ }^{216}$ The Order stated that the Philippines

"shall deposit, at the appropriate time, a copy of this Order enclosing the official map reflecting the West Philippines Sea with the Secretary-General of the United Nations and notify accordingly relevant international organizations, such as the International Hydrographic Organization and the United Nations Conference on the Standardization of Geographical Names."217

This unilateral move is not bound to make any significant changes to the status quo but it reflects the surging nationalist fervor that has come to the forefront as a result of these disputes.

\section{AFP Modernization}

The withdrawal of American forces from the Philippines in 1992 and the Chinese occupation of Mischief Reef in 1995 proved just how far the AFP had atrophied. The Philippines air force found itself with a mere five F-5 fighters, while the navy possessed a single frigate, nine offshore patrol vessels and eight amphibious landing craft, all of which are essentially WWII relics. ${ }^{218}$ The Philippines has been among the weakest members of ASEAN in both military capability and defense spending. ${ }^{219}$ It currently

\footnotetext{
${ }^{216}$ Ibid.

${ }^{217}$ Ibid.

${ }^{218}$ Storey, Ian, Southeast Asia and the Rise of China: The Search for Security (New York: Routledge, 2011), Pg. 256

219 "Towards a Self-Reliant Defense Force: A look into the AFP Modernization Law," National Defense College of the Philippines, 2013, http://www.ndcp.edu.ph/publications/6\%20GAUD\%20Towards\%20a\%20Self\%20Reliant\%20Def ense\%20Force.pdf (Accessed September 11, 2013)
} 
spends $\$ 2.9$ billion in defense annually, which is less than five out of the six claimants in the SCS. ${ }^{220}$

In the aftermath of Chinese seizure of Mischief Reef in 1995, the Philippine “congress introduced a defense modernization bill which called for the acquisition of modern jet fighters and patrol vessels.”221 The new bill was titled Republic Order 7898 and it was meant to accomplish its goal in 15 years. ${ }^{222}$ The Order was to allocate $\$ 7.7$ billion for the program over the span of those 15 years; however, the 1997 Asian Financial Crisis derailed the initiative. ${ }^{223}$ The result was that for the span of the 15 years that RA 7898 remained active; only 55\% of the 504 projects that were planned were implemented. ${ }^{224}$ However, there have been some positive developments regarding the modernization of the AFP in recent years.

In 2012 Philippine President Aquino signed RA 10349, also known as the revised AFP Modernization Act. ${ }^{225}$ Following on his pledge to modernize the AFP, President

220 “SIPRI Military Expenditure Database”, Stockholm International Peace Research Institute,(2012), http://www.sipri.org/research/armaments/milex/research/armaments/milex/research/armaments/mi lex/milex_database (Accessed September 11, 2013)

${ }^{221}$ Storey, Ian, Southeast Asia and the Rise of China: The Search for Security (New York: Routledge, 2011), Pg. 256

222 “Towards a Self-Reliant Defense Force: A look into the AFP Modernization Law,” National Defense College of the Philippines, 2013, http://www.ndcp.edu.ph/publications/6\%20GAUD\%20Towards\%20a\%20Self\%20Reliant\%20Def ense\%20Force.pdf (Accessed September 11, 2013)

${ }^{223}$ Fisher, Richard D. Jr., "Defending the Philippines: Military Modernization and the Challenges Ahead,” Center for a New American Security, 2012, http://www.cnas.org/files/documents/publications/CNAS_ESCS_bulletin3.pdf (Accessed September 10, 2013)

224 "Towards a Self-Reliant Defense Force: A look into the AFP Modernization Law," National Defense College of the Philippines, 2013, http://www.ndcp.edu.ph/publications/6\%20GAUD\%20Towards\%20a\%20Self\%20Reliant\%20Def ense\%20Force.pdf (Accessed September 11, 2013)

${ }^{225}$ Goldman, Justin, “President Aquino’s Second Half: Minimum Credible Defense in Contested Waters?” 
Aquino has been true to his word. This is reflected in the fact that the government has spent more than \$395 million on AFP modernization in the first few months of his term in contrast to the $\$ 51$ million annual average of the past 15 years. ${ }^{226}$ The PAF plans to acquire a small number F-16 fighter jets along with 6-12 Surface Attack Aircraft (SAA)/Lead-in Fighter Training (LIFT) aircrafts. The South Korean T/A-50 is among the top contenders. The PAF is also expected to acquire new long-range radars to enhance its air defense capabilities. ${ }^{227}$

The navy in particular has benefited from the new modernization program. In an address to the Navy, Aquino stated that the "Philippines would acquire two new frigates, two helicopters capable of antisubmarine warfare, three fast vessels for coastal patrols and eight amphibious assault vehicles by 2017."228 The AFP also has two ambitious programs it would like to see fulfilled. The first is to acquire two Landing Platform Dock (LPD) ships with a displacement of 5,000-10,000 tons. These ships would be capable of supporting amphibious operations as well as conducting disaster relief missions. The second program would be to purchase a submarine by $2020 .{ }^{229}$ Due to the fact that the

The Jamestown Foundation China Brief 13 (2013), Pg. 10, http://www.jamestown.org/uploads/media/cb_06_21.pdf (Accessed December 5, 2013)

${ }^{226}$ Fisher, Richard D. Jr., "Defending the Philippines: Military Modernization and the Challenges Ahead," Center for a New American Security, 2012, http://www.cnas.org/files/documents/publications/CNAS_ESCS_bulletin3.pdf

${ }^{227}$ Ibid. (Accessed September 10, 2013)

${ }^{228}$ Goldman, Justin, “President Aquino’s Second Half: Minimum Credible Defense in Contested Waters?” The Jamestown Foundation China Brief 13 (2013), Pg. 10, http://www.jamestown.org/uploads/media/cb_06_21.pdf (Accessed December 5, 2013)

${ }^{229}$ Fisher, Richard D. Jr., "Defending the Philippines: Military Modernization and the Challenges Ahead," Center for a New American Security, 2012, http://www.cnas.org/files/documents/publications/CNAS_ESCS_bulletin3.pdf (Accessed September 10, 2013) 
Philippines does not currently operate any submarines, this would be a significant acquisition.

The U.S. has been encouraging other allies in the region to provide the Philippines with weapons for its AFP program. Japan in particular has been cited due to the fact that it possesses one of the most capable navies in the region and has excess ships it can offer to the Philippines. Additionally, Japan has significant MCM capabilities and could provide the Philippines with some of these state of the art vessels. ${ }^{230}$ This could be a route worthwhile exploring since MCM ships would fall within Japanese guidelines for military weapons sales due to the fact that those vessels do not have offensive capabilities.

\section{Japan-Philippine Relations}

While Sino-Philippine relations have seen a turn for the worse since the 1990s, Japan-Philippine relations have been on an upsurge. Japan is currently the Philippines’ largest trading partner accounting for $14.2 \%$ of the Philippines' total trade. ${ }^{231}$ "Exports to Japan totaled $\$ 4.767$ billion while imports were valued at $\$ 3.407$ billion, posting a trade surplus of $\$ 1.359$ billion.”232 This positive economic relationship was reinforced in 2006 when Japan and the Philippines signed an economic partnership agreement. ${ }^{233}$ This agreement has facilitated investment coming from Japan as well as added support for

\footnotetext{
${ }^{230}$ Ibid.

231 “Foreign Trade Statistics of the Philippines: First Semester 2012,” National Statistics Office, 2012, http://www.census.gov.ph/content/foreign-trade-statistics-philippines-first-semester-2012 (Accessed, December 10, 2013)

232 Ibid.

233 “Agreement Between Japan and the Republic of the Philippines for an Economic Partnership," Ministry of Foreign Affairs of Japan, 2006, Pg. 120, http://www.mofa.go.jp/region/asia-paci/philippine/epa0609/main.pdf (Accessed, December 10, 2013)
} 
Philippine workers overseas. Japan has been the biggest source of financial aid to the Philippines, contributing $\$ 9.4$ billion over the past 23 years. This contribution amounts to $51 \%$ of all foreign loans into the country. ${ }^{234}$

The free trade agreement (FTA) between the two countries has also facilitated the employment of Philippine workers in Japan, particularly in the health industry. This is due to the fact that Japan's aging population have raised the costs of healthcare, something which has forced Japan to open its doors to foreign workers to care for the elderly. Out of the 667,226 overseas foreign workers (OFW) deployed by the Philippines around the world, 77,870 have gone to Japan. Out of that number, 68, 257 work as domestic helpers while 7,683 were employed as professional nurses in the year $2000 .^{235}$ Remittances from these OFWs in Japan are also a key source of income for the Philippine government. These remittances have grown steadily over the years and in 2005 amounted to roughly $\$ 300$ million. This represented a significant increase from the $\$ 122$ million that was sent in $1997 .^{236}$

Japan-Philippine security relations have also seen positive developments, particularly in recent years as both countries have found a common cause against China. Numerous summits have occurred between the two sides in an effort to expand the scope of their bilateral relations into the security sphere. In 1998 Japan helped the Philippines create a civilian coast guard, and has continued to provide training to its personnel ever

\footnotetext{
${ }^{234}$ Cortez, Michael Angelo A., "Japan-Philippines Free Trade Agreement: Opportunities for the Movement of Workers,” Ritsumeikan International Affairs 7 (2009), Pg. 126, http://www.ritsumei.ac.jp/acd/re/k-rsc/ras/04_publications/ria_en/7_05.pdf (Accessed December 11, 2013)

${ }^{235}$ Ibid. Pg. 129

${ }^{236}$ Ibid. Pg. 130-131
} 
since. ${ }^{237}$ In a 2011 summit between Philippine President Aquino and then Prime Minister Noda the two agreed to dispatch JCG vessels to the Philippines in order to strengthen the training for the Philippine Coast Guard (PCG). The two leaders also agreed to

"promote and cooperation between their defense authorities, such as reciprocal visits between the Chief of Staff of Japanese Maritime Self Defense Forces (JMSDF) and the Flag Officer of the Philippine Navy, port calls in the Republic of the Philippines by JMSDF vessels, and the holding of the Japan-Philippines Maritime Chief of Staff Meeting."238

Furthermore, in a similar summit in 2013 between President Aquino and Prime Minister Abe, Japan stated that it would provide 10 patrol vessels to the PCG through its ODA program. This would help bolster Philippine maritime patrol capabilities. ${ }^{239}$ The 10 patrol ships are 40 meters long and are equipped with modern electronics. It is reported that two additional larger vessels are being considered for transfer to the PCG under a similar grant. $^{240}$

In a landmark summit between Japanese Defense Minister Itsunori Onodera and Philippine Defense Secretary Voltaire Gazmin in 2013, the two men discussed many topics including the importance of the rule of maritime law, the American rebalance to Asia, and possible Japanese access to Philippine naval bases. Regarding the rule of law,

${ }^{237}$ Sato, Yoichiro, “Japan Aid to the Philippines a Warning to China,” East Asia Forum, 2013, http://www.eastasiaforum.org/2013/08/29/japan-aid-to-the-philippines-a-warning-to-china/ (Accessed, November 1, 2013)

238 "Japan-Philippines Joint Statementon the Comprehensive Promotion of the "Strategic Partnership" between Neighboring Countries Connected by Special Bonds of Friendship,” Kantei, 2011, http://www.kantei.go.jp/foreign/noda/diplomatic/201109/27philippines_e.html (Accessed October 12, 2013)

239 “Japan-Philippines Summit Meeting,” Ministry of Foreign Affairs of Japan, 2013, http://www.mofa.go.jp/region/page6e_000121.html (Accessed, October 12, 2013)

${ }^{240}$ Hong, Zhao, “China-Philippines Relations Stunted by South China Sea Dispute,” Institute of Southeast Asian Studies SEAS Perspective 17 (2013), Pg. 3, http://www.iseas.edu.sg/documents/publication/ISEAS\%20Perspective\%202013_17.pdf (Accessed November 11, 2013) 
Onodera commented that current situation in the SCS should not be changed with the use of force; he was clearly alluding to the recent Chinese encroachment on the Scarborough Shoal. ${ }^{241}$ Onodera also remarked that he and Gazmin agreed that Japan and the Philippines should work together to make the American rebalance in the region a reality. ${ }^{242}$ In a more significant development, Secretary Gazmin indicated that Japan could potentially be offered access to naval bases in the Philippines in the same manner as the United States. He said that "as far as Japan is concerned, we do welcome other countries - particularly Japan since Japan is a strategic partner — in accordance with our existing protocols.” ${ }^{243}$ However, it is important to note that if the Philippine government is serious about providing Japanese forces access to its bases, it would need to negotiate a Visiting Forces Agreement (VFA) in the same manner as it has done with the United States. ${ }^{244}$

The pattern has been very clear. As the ECS and SCS disputes with China have escalated, Japan and the Philippines have found common ground to expand their bilateral cooperation from the economic into the security realm. The two countries share common interests in protecting the SLOC in the SCS, and while Japan professes neutrality on the SCS disputes, it appears that it has opted to balance against China by providing assistance

${ }^{241}$ Dizon, Nikko, PH, Japan Defense Chiefs Welcome Deepening Ties,” Philippine Daily Inquirer, 2013, http://globalnation.inquirer.net/78899/ph-japan-defense-chiefs-welcome-deepening-ties (Accessed October 5, 2013)

${ }^{242}$ Ibid.

${ }^{243}$ Keck, Zachary, “Made in China: A US-Japan-Philippines Axis?” The Diplomat, 2013, http://thediplomat.com/2013/06/made-in-china-a-us-japan-philippines-axis/ (Accessed October 5, 2013)

${ }^{244}$ Amador III, Julio S., “The Philippines’ Security Cooperation with the United States and Japan,” East-West Center, Asia Pacific Bulletin 227 (2013), http://www.eastwestcenter.org/sites/default/files/private/apb227.pdf (Accessed October 10, 2013) 
to the Philippines in the form of monetary aid, coast guard training, and the provision of patrol vessels. To further highlight these developments, Defense Minister Onodera expressed his concerns with the deteriorating situation in the SCS and the potential effects this could have on the ECS. In a telling statement to his counterpart, Defense Secretary Gazmin, Onodera said that:

\begin{abstract}
"in the East China Sea and the South China Sea, we are both facing common concerns, and those issues of concerns should be based on the rule of law and we agreed on that. We agreed that Japan and the Philippines, as good neighbors, to further strengthen our defense cooperation.",245
\end{abstract}

Although it is certain that the two countries have come closer as a result of China’s increasingly assertive policy towards its maritime territorial disputes, Japan still hopes that ASEAN solidarity on the SCS disputes will pave the way for a united front to China and ultimately result in a peaceful resolution to the conflict. However, in order to make that happen, Japan feels that it must increase its security commitments in the SCS in order to convey to both China and ASEAN that as a regional power, Japan is interested in the amicable resolution to the disputes. ${ }^{246}$ Therefore, the growing number of economic and defense cooperation agreements between Japan and Southeast Asian countries are considered a tool to provide a proper balance to China and ensure a more equitable negotiation process.

\footnotetext{
${ }^{245}$ Dizon, Nikko, PH, Japan Defense Chiefs Welcome Deepening Ties,” Philippine Daily Inquirer, 2013, http://globalnation.inquirer.net/78899/ph-japan-defense-chiefs-welcome-deepening-ties (Accessed October 5, 2013)

${ }^{246}$ Sato, Yoichiro, “Japan Aid to the Philippines a Warning to China,” East Asia Forum, 2013, http://www.eastasiaforum.org/2013/08/29/japan-aid-to-the-philippines-a-warning-to-china/ (Accessed, November 1, 2013)
} 


\section{Chapter V: Socialist Republic of Vietnam Case Study}

\section{Background}

Like the Philippines, Vietnam has endured centuries of colonization by foreign powers. However, Vietnam is the only country in Southeast Asia to have ever been part of the Chinese Empire. This began with the annexation of the northern territories of Vietnam by Han Imperial troops in 111 BCE. However, as the Tang Dynasty collapsed in $907 \mathrm{CE}$, the Vietnamese began a 20 year struggle that would eventually gain them independence for the first time in nearly a thousand years. ${ }^{247}$ From this point forward Vietnamese rulers sought to preserve their hard-won independence by accepting a tributary status to their former colonial masters. These agreements would at times be broken due to repeated Chinese attempts to reconquer the area during the Yuan, Ming and Qing Dynasties; however, no invasion of Vietnam would be successful until the French formally made it a colony in 1885. Its colonial status would be preserved until the devastating French defeat at Dien Bien Phu in 1954. The resulting Geneva conference split the country in two at the $17^{\text {th }}$ parallel, a situation which would endure until 1976 . In 1976 the country was reunified to under the Socialist Vietnamese Republic (SRV). ${ }^{248}$

As previously mentioned, Vietnam lost control of the Paracels to China after a naval battle in 1974; however, the country controls the largest number of features in the Spratly archipelago, which it calls Truong Sa. The 21 features are:

(Vietnamese Name/International Name)

1. Da Lat or Ladd Reef

2. Dao Truong Sa or Spratly Island

\footnotetext{
${ }^{247}$ Storey, Ian, Southeast Asia and the Rise of China: The Search for Security (New York: Routledge, 2011), Pg. 101-102

${ }^{248}$ Ibid. Pg. 102-106
} 
3. Da Tay or West London Reef

4. Da Giua or Central Longdon Reef

5. Dao Dong or East London Reef

6. Dao An Bang or Amboyan Reef

7. Thuyen Chai or Barque Canada Reef

8. Da Phan Vinh or Pearson Reef

9. Bai Toc Tan or Alison Reef

10. Da Nui Le or Cornwallis South Reef

11. Da Tien Nu or Tennent Reef

12. Da Lon or Great Discovery Reef

13. Da Len Dao or Landsdowne Reef

14. Da Hi Gen

15. Dao Sinh Ton or Sin Cowe Island

16. Da Gri-san

17. Dao Nam Yet or Namyit Island

18. Dao Son Ca or Sand Cay

19. Da Nui Thi or Petley Reef

20. Dao Song Tu Tay or Southwest Cay

21. Da Nam or South Reef ${ }^{249}$

In addition to its substantial holdings in the Spratlys, Vietnam, in stark contrast to the

Philippines, has some of the most heavily fortified structures in the area. The largest

feature in the group it controls is Spratly Island proper (See Figure 8). The island has a

“solid runway, a pier, at least 35 building structures, around 20 storage tanks, at least 20 gun emplacements, at least 5 battle tanks and some parabolic disk antennas and a spoon rest radar. In April 2009, Philippine aerial surveillance found a two newly-constructed two-story building in the Lagos Island with 12 newly-installed light posts and 12 wind mills.",250

Southwest Cay is also heavily fortified, sporting gun emplacements, bunkers, barracks, a helipad, and polarized dipole array antennas. ${ }^{251}$

\footnotetext{
${ }^{249}$ Laserna Jr., Manuel J., "The Spratlys: Legal Basis of the Claim of the Socialist Republic of Vietnam,” Paracel and Spratly Islands Forums, 2008, http://paracelspratlyislands.blogspot.com/2008/01/legal-basis-of-vietnams-claims.html (Accessed December 12, 2013)

${ }^{250}$ Banlaoi, Rommel C., Philippines-China Security Relations: Current Issues and Emerging Concerns (Quezon City: Philippine Institute for Peace, Violence and Terrorism Research, 2012), Pg. 59

${ }^{251}$ Ibid. Pg. 60
} 


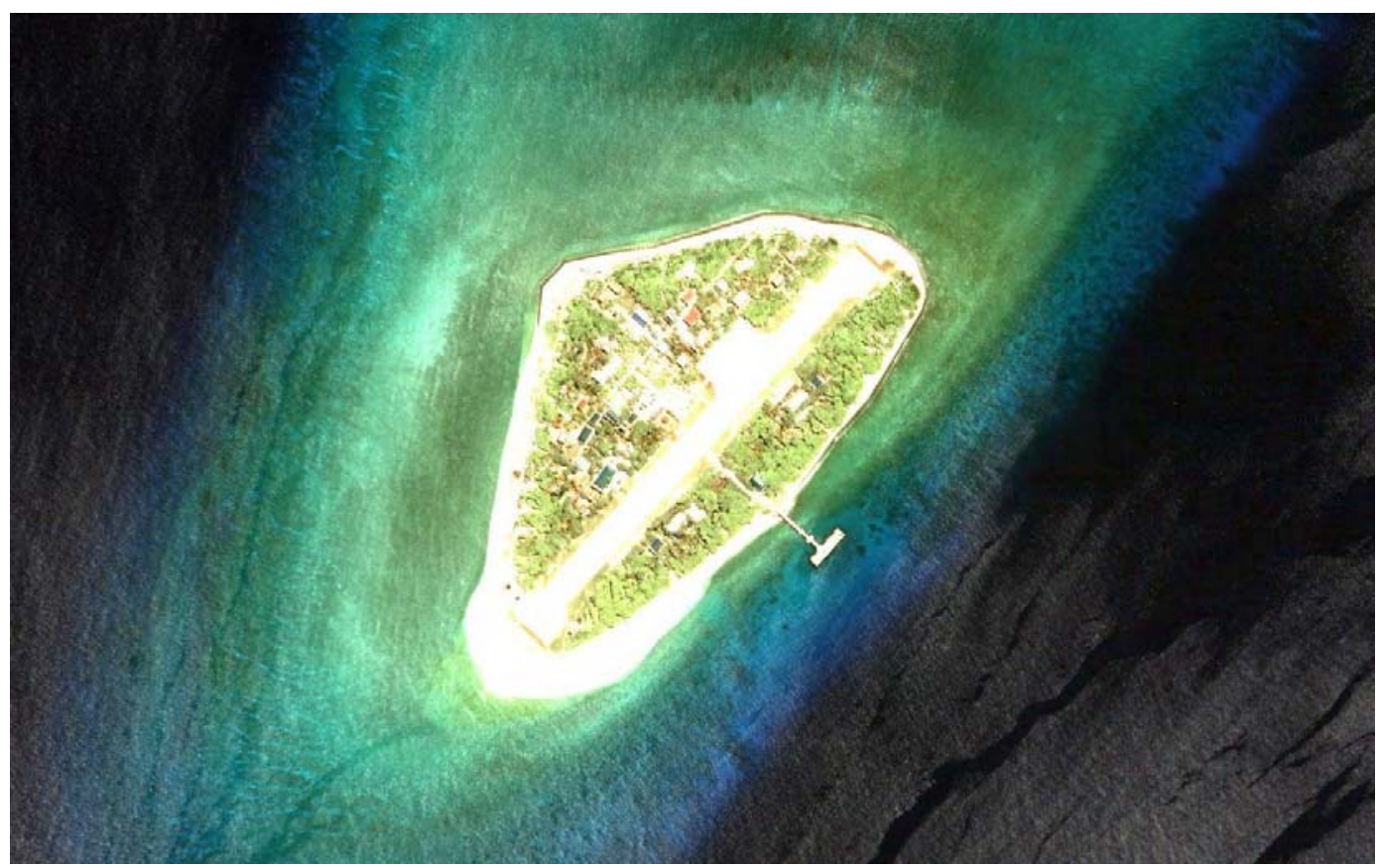

Figure 8: Spratly Island proper. Source Google Maps

Much like the Philippines, Vietnam has economic and security interests in the SCS. The SCS continues to provide a significant amount of energy for the country, and potential reserves could all but guarantee energy security for decades to come. Likewise, the marine resources of the SCS continue to provide a vital role in the Vietnamese economy. Because much of Vietnam's economic security relies on the bounty of the SCS, it is among the most politically active in pursuing its claims in the region.

\section{Energy Resources}

Vietnam is currently one of the top oil producers in the area. State-owned company PetroVietnam singularly accounts for $26 \%$ of Vietnams' total production by producing 24.4 million tons of oil annually. ${ }^{252}$ Unfortunately oil production has been

\footnotetext{
${ }^{252}$ Buszynski, Leszek, “The South China Sea: Oil, Maritime Claims, and U.S.-China Strategic Rivalry,” The Washington Quarterly 35:2 (2012), Pg. 141, https://csis.org/files/publication/twq12springbuszynski.pdf (Accessed November 3, 2013)
} 
declining since 2004, which has motivated Vietnam to extend exploration contracts to foreign firms in an effort to locate and exploit new fields. This has directly led to confrontations with China over disputed areas in the SCS.

Nevertheless, there have been positive developments in recent years which could potentially ensure Vietnamese energy security for the foreseeable future. In 2013, successful exploration led to an increase in proven reserves from 0.6 billion barrels to 4.4 billion barrels. Much of Vietnam's waters remain underexplored as a result of its ongoing disputes with China, which leads the EIA to predict that further exploration may result in larger proven reserves. This discovery places Vietnam as the third largest holder of proven oil reserves in Asia. ${ }^{253}$ Vietnam's current oil consumption is estimated to be around 387,880 bpd; a figure that is projected to grow at roughly 2.6\% annually. In 2012 domestic oil production was roughly 364,000 bpd, which brings Vietnam close to energy self-sufficiency. For the short term Vietnam is expected to remain a net oil importer due to the fact that its current fields have already peaked, as well as the fact that its refining capacity is only $140,000 \mathrm{bpd}$; although there are plans to expand this capacity to at least 200,000 bpd. Vietnam now faces the challenge of trying to exploit its newly discovered reserves while simultaneously trying to deter Chinese obstruction in developing these fields. $^{254}$

The SRV is currently self-sufficient in natural gas, although it is projected to fall short of supply by 2025. With 24.7 tcf of proven natural gas reserves, Vietnam is not

\footnotetext{
253 “Vietnam: Overview/Data,” Energy Information Administration, 2013, http://www.eia.gov/countries/country-data.cfm?fips=vm (Accessed November 3, 2013) ${ }^{254}$ Ibid.
} 
lacking the resources to exploit. ${ }^{255}$ Rather, it lacks the expertise to do so. As with its oil industry, Vietnam has relied on granting exploration and extraction contracts to numerous foreign firms. Nevertheless, Vietnam faces the same dilemma with its natural gas fields as it does with the oil fields. That is, the threat of Chinese obstruction in disputed maritime areas.

\section{Marine Resources}

Having a coastline of $3,260 \mathrm{~km}$ and an EEZ of more than 1 million $\mathrm{km}^{2}$, marine sources are a vital component of the Vietnamese economy and its food security. ${ }^{256}$ In 2010 seafood exports accounted for 7\% of Vietnam's total exports; providing the second largest amount of foreign exchange. ${ }^{257}$ The SRV also has the second largest amount of fishers in the region after China. ${ }^{258}$ The steady growth of the fishing sector has allowed Vietnam to become one of one the largest seafood exporters in the world. In 2007 Vietnam ranked $12^{\text {th }}$ in fishing yields, $7^{\text {th }}$ in fishing export value, and $3^{\text {rd }}$ in aquatic species farming. ${ }^{259}$ It is believed that there are about 3.4 million people in Vietnam who

\footnotetext{
${ }^{255}$ Ibid.

256 “Vietnam’s Fishery Products Export in the First 9 Months of 2012,” Vietnam Trade Promotion Agency, 2012, http://www.vietrade.gov.vn/en/index.php?option=com_content\&view=article\&id=1622:vietnams-fishery-products-export-in-the-first-9-months-of-2012\&catid=270:vietnam-industrynews\&Itemid=363 (Accessed November 10, 2013)

${ }^{257}$ Bouchat, Clarence J., Dangerous Ground: The Spratly Islands and U.S. Interests and Approaches,” U.S. Army War College Press, 2013, Pg. 4, http://www.strategicstudiesinstitute.army.mil/pdffiles/PUB1187.pdf (Accessed November 10, 2013)

${ }^{258}$ Khemakorn, Pakjuta, "Sustainable Management of Pelagic Fisheries in the South China Sea Region," United Nations - The Nippon Foundation, 2006, Pg. 29, http://www.un.org/depts/los/nippon/unnff_programme_home/fellows_pages/fellows_papers/khem akorn_0607_thailand.pdf (Accessed November 12, 2013)

259 “The Stages in the Development of Vietnam Fisheries Sector,” Directorate of Fisheries, 2012,
} 
are directly involved in aquaculture activities and in capture fisheries. ${ }^{260}$ In the first 9 months of 2012 Vietnam exported roughly $\$ 4.5$ billion worth of seafood. The U.S., E.U., and Japan are the main importers. Japan in particular has been increasing its purchases of seafood from Vietnam which was reflected by a $19 \%$ growth on a year by year basis during this period. Seafood exports to Japan were valued at \$795 million and were $17.53 \%$ of the total Vietnamese seafood export in 2012. ${ }^{261}$

Like the Philippines, Vietnam relies on fisheries and aquatic products for its food consumption. It is estimated that fish provide 30-40 percent of the protein in Vietnamese diets. In 1995, the National Institute of Nutrition in Hanoi estimated that the annual fish consumption per capita in Vietnam was $18.5 \mathrm{~kg} .{ }^{262}$ Therefore, access to the SCS in order to secure its food and economic needs is vital. Repeated clashes between Chinese maritime vessels and Vietnamese fishermen are among the top concerns for the Vietnamese government as it tries to expand an already lucrative industry.

\section{Sino-Vietnamese Disputes}

Sino-Vietnamese security relations are among the most complex and conflict prone in the region. In effect:

http://www.fistenet.gov.vn/introduction/about-directorate-of-fisheries/history-of-fisheriesdevelopment (Accessed November 10, 2013)

${ }^{260}$ Huu Dung, Nguyen, "Status of Fish Trade and Food Security in Viet Nam," Food and Agriculture Organization, 2003, http://www.fao.org/docrep/006/y4961e/y4961e0k.htm (Accessed November 10, 2013)

261 “Vietnam’s Fishery Products Export in the First 9 Months of 2012,” Vietnam Trade Promotion Agency, 2012, http://www.vietrade.gov.vn/en/index.php?option=com_content\&view=article\&id=1622:vietnams-fishery-products-export-in-the-first-9-months-of-2012\&catid=270:vietnam-industrynews\&Itemid=363 (Accessed November 10, 2013)

${ }^{262}$ Huu Dung, Nguyen, "Status of Fish Trade and Food Security in Viet Nam," Food and Agriculture Organization, 2003, http://www.fao.org/docrep/006/y4961e/y4961e0k.htm (Accessed November 10, 2013) 
"Two millennia of Chinese overlordship, combined with an intense relationship over the past 60 years characterized by extremes of amity and enmity, have shaped Vietnam's China psyche to deeply ambivalent: respect for a fraternal socialist country whose economic reforms Hanoi seeks to emulate, coexisting with deep resentment, bordering hatred, of Chinese condescension, bullying and perceived attempts to control the country's political destiny.,263

The amity that existed between the CCP and the Communist Party of Vietnam degenerated almost as soon as the SRV was founded in 1976 as a result of the PRC takeover of the Paracels two years prior. Hanoi’s earlier position supporting PRC claims to the SCS were repudiated as the SRV restated its claims to the Paracels and the Spratly archipelagos. ${ }^{264}$ Vietnam's loss of the Paracels resulted in its first occupation of six Spratly Island features as a form of retaliation against China. Although the occupation was initially conducted by South Vietnamese forces, upon reunification SRV troops seized control of the islets and continued to occupy 15 more. $^{265}$

The disputes between the two countries in the SCS remained relatively stable until 1988. In 1988 Chinese and Vietnamese naval forces clashed in the Spratly Islands over Fiery Cross Reef. The battle would end with the withdrawal of Vietnamese forces after incurring heavy losses. Three Vietnamese naval vessels and 72 sailors were lost in that battle. ${ }^{266}$ This event marked China's first occupation of a Spratly Island feature. The 1974 seizure of the Paracel Islands by China, as well as the 1988 battle that allowed China to

${ }^{263}$ Storey, Ian, Southeast Asia and the Rise of China: The Search for Security

(New York: Routledge, 2011), Pg. 101

${ }^{264}$ Emmers, Ralf, Geopolitics and Maritime Territorial Disputes in East Asia (New York: Routledge, 2010), Pg. 69

${ }^{265}$ Ibid.

${ }^{266}$ Burgess, J. Peter, “The Politics of the South China Sea: Territoriality and International Law," Security Dialogue 34:1 (2003), Pg. 9, http://community.middlebury.edu/ scs/docs/Burgess,\%20Politics\%20of\%20the\%20South\%20Chi na\%20Sea-Territoriality\%20and\%20.pdf (Accessed December 5, 2013) 
gain a foothold in the Spratly Islands were facilitated by the changing power dynamics in the region.

The events of 1974 were made possible partly because of Sino-American rapprochement and because of U.S. troop withdrawal from Vietnam in 1973. "The U.S. role was confined to helping the South Vietnamese escape from the islands. ${ }^{267}$ In the case of the 1988 events, the Chinese were aided by the fact that the Soviet Union had begun to withdraw aid to Vietnam and was pursuing a normalization of relations with the PRC after decades of growing enmity between the two former allies. The Soviet Union's position as a military ally for Vietnam had effectively ended, giving China the opportunity to enforce its claims militarily. ${ }^{268}$ The Chinese reasoned that neither power would be concerned over the SCS disputes. Their calculations would be proven correct by the relatively muted response from both the U.S. and the U.S.S.R. in the aftermath of the Fiery Reef clash.

The disputes remained heated through 1992 when the Vietnamese government accused China of drilling for oil in Vietnamese waters and landing troops in a reef. In that same year the Chinese government seized 20 Vietnamese cargo ships which were transporting goods from Hong Kong. ${ }^{269}$ Even though military clashes between the two countries have not been commonplace since the early 1990s, the confrontations have merely switched to the civilian sphere. The numerous Chinese maritime enforcement

${ }^{267}$ Emmers, Ralf, Geopolitics and Maritime Territorial Disputes in East Asia

(New York: Routledge, 2010), Pg. 69

${ }^{268}$ Ibid. Pg. 69-70

${ }^{269}$ Burgess, J. Peter, “The Politics of the South China Sea: Territoriality and International Law,” Security Dialogue 34:1 (2003), Pg. 9, http://community.middlebury.edu/ scs/docs/Burgess,\%20Politics\%20of\%20the\%20South\%20Chi na\%20Sea-Territoriality\%20and\%20.pdf (Accessed December 5, 2013) 
agencies have been accused of harassing fishermen and oil exploration ships in the disputed seas. Vietnam claims that since 2005 the Chinese have seized 63 fishing boats along with 725 crew members. These fishermen are then required to pay exorbitant fines for their release. ${ }^{270}$ In similar fashion, Vietnam accuses these agencies of obstructing its energy companies from conducting oil and natural gas exploration in its waters. In a recent event, Chinese vessels cut the seismic cables of a ship belonging to Vietnam's state-owned energy company, PetroVietnam. ${ }^{271}$ Although China and Vietnam have settled on the demarcation of their respective EEZs and marine borders along the Gulf of Tonkin, the territorial disputes in the SCS remain unresolved issues between the two neighbors.

It is clear that Sino-Vietnamese security relations have been largely unstable due to Vietnamese perception of a "China threat.” During the Shangri-La Dialogue in 2013, Vietnamese Prime Minister Nguyen Tan Dung delivered the keynote address in which he made his security perception of China very clear by stating that "somewhere in the region, there have emerged preferences for unilateral might, groundless claims, and actions that run counter to international law and stem from imposition and power politics." ${ }^{272}$ The

\footnotetext{
${ }^{270}$ Buszynski, Leszek, “The South China Sea: Oil, Maritime Claims, and U.S.-China Strategic Rivalry,” The Washington Quarterly 35:2 (2012), Pg. 143, https://csis.org/files/publication/twq12springbuszynski.pdf (Accessed November 3, 2013)

${ }^{271}$ Cronin, Patrick M., China's Global Quest for Resources and Implication for the United States,” Center for a New American Security, 2012, http://www.cnas.org/files/documents/publications/CNAS\%20Testimony\%20Cronin\%20012612_1 .pdf (Accessed December 20, 2013)

${ }^{272}$ Dung, Nguyen Tan, "Shangi-La Dialogue 2013 Keynote Address," Shangri-La Dialogue: The IISS Asia Security Summit, 2013, http://www.iiss.org/en/events/shangri\%20la\%20dialogue/archive/shangri-la-dialogue-2013c890/opening-remarks-and-keynote-address-2f46/keynote-address-d176 (Accessed December 5, 2013)
} 
statement was made in clear reference to the PRC. China's military modernization and increasingly assertive SCS policy has been a major concern for Vietnamese leaders, not only because of their proximity to mainland China, but also because Vietnam's military capabilities are significantly inferior to those of the PLA. Nonetheless, while Vietnam neither possess the resources to match Chinese military expenditure, nor is it able to meet a serious PLA challenge on the SCS, it has been pursuing a strategy of minimum credible defense in order to deter further Chinese incursions into what it believes are its territorial waters. This has led to increasing defense budgets and modernization programs for the Vietnamese military.

\section{VPA Modernization}

The Vietnam People's Army (VPA) is the official name for the active military services of Vietnam. Like the PLA it encompasses the three main services: the ground forces, navy, and air force. Through the late 80s and early 90s the VPA saw a significant decrease in funding. This was due to the suspension of financial assistance from the U.S.S.R. as well as the fact that Vietnam's economy was unable to support any substantial acquisitions. However, increased Chinese activities in the SCS as well as economic growth prompted the SRV to begin modernizing its armed forces. The Stockholm International Peace Research Institute (SIPRI) estimated that by 2012 the SRV spent roughly $\$ 3.36$ billion in defense annually. ${ }^{273}$

Because the focus of Vietnam's security agenda has been the SCS, its modernization program concentrates on acquisitions that enhance its naval and air

\footnotetext{
273 “SIPRI Military Expenditure Database”, Stockholm International Peace Research Institute,(2012), http://www.sipri.org/research/armaments/milex/research/armaments/milex/research/armaments/mi lex/milex_database (Accessed April 11, 2013)
} 
capabilities. Russia has been the main benefactor of Vietnam's foreign purchases. Since 1995 the VPA has acquired 12 SU-27S/Flanker-B and 4 SU-30MK fighters to enhance its air wings. ${ }^{274}$ The four SU-30MKs are to be supplemented by an additional 16 in the coming years. ${ }^{275}$ Vietnam's geographical proximity to the Spratly Islands, where it maintains roughly 600 troops, allows these fighters to conduct longer sorties than their counterparts based in Southern China. These fighters come equipped with modern Russian anti-ship and anti-air missiles, which significantly increase Vietnam's air force which has relied on obsolete MIG 21 fighters for decades. To enhance its defenses Vietnam has also acquired two S-300 SAM platforms and two K-300 Bastion-P Coastal defense systems. ${ }^{276}$

In addition to enhancing its air capabilities, the VPA has been procuring a substantial amount of naval hardware. The most significant of these acquisitions has been the purchase of six Kilo-class submarines from Russia in a deal valued at $\$ 1.8$ billion. ${ }^{277}$ Another important purchase has been the Gepard-3 frigates, also procured from Russia. The VPA believed that acquiring the "stealthy Gepard Class light frigates will add surface warfare and patrol punch, alongside new Molniya/ Project 12418 missile-armed Fast Attack Craft. ${ }^{, 278}$ While the first two Gepards were built for surface warfare, the next

\footnotetext{
274 “Trade Registers,” Stockholm International Peace Research Institute, 2012, http://portal.sipri.org/publications/pages/transfer/trade-register (Accessed, October 15, 2013)

${ }^{275}$ Todore, Greg, "Vietnam’s Military Growth Raising Eyebrows in the Region,” South China Morning Post, 2012, http://www.scmp.com/article/991004/vietnams-military-growth-raising-eyebrows-region (Accessed, October 15, 2013)

276 “Trade Registers,” Stockholm International Peace Research Institute, 2012, ${ }^{277}$ Ibid. http://portal.sipri.org/publications/pages/transfer/trade-register (Accessed, October 15, 2013)

278 “Vietnam’s New Military Buys,” Defense Industry Daily, 2014, http://www.defenseindustrydaily.com/vietnam-reportedly-set-to-buy-russian-kilo-class-subs05396/ (Accessed January 23, 2013)
} 
two will optimized for anti-submarine warfare; clearly indicating Vietnam's fear of China’s growing submarine capabilities. ${ }^{279}$

Even though Vietnam has been predominantly reliant on Russian weapons to modernize its inventory, it appears that it has made efforts to diversify and acquire hardware from western firms. In a recent event the SRV concluded a deal to purchase four SIGMA-class ships from the Netherlands. These ships are modular and can be modified to fit the specifications of the client state. Vietnam's SIGMA 9814 vessels will measure about 98 meters and weigh slightly less than the 2,100-ton Gepard at 1,950 tons. The ships come equipped with ASMs, torpedo launchers and air-defense missiles. ${ }^{280}$ Vietnam is also in negotiations with India to purchase its BrahMos supersonic cruise missile to enhance its missile capabilities. ${ }^{281}$

There are also indications that Vietnam is attempting to develop a domestic shipbuilding capability. Roughly " $\$ 3.8$ billion is reported to have been invested to build 30-40 400-ton warships.” ${ }^{282}$ Another investment has been made to construct a large military harbor at Haiphong. When completed, it will be the second largest naval base in the country after Cam-Ranh Bay. This harbor will have the capacity to dock 40,000-ton

${ }^{279}$ Ibid.

280 "More than the Sum of its Parts: Dutch SIGMA ships for Vietnam,” Defense Industry Daily, 2013, http://www.defenseindustrydaily.com/more-than-the-sum-of-its-parts-dutch-sigma-ships-forvietnam-07173/ (Accessed December 5, 2013)

${ }^{281}$ Todore, Greg, "Vietnam’s Military Growth Raising Eyebrows in the Region," South China Morning Post, 2012, http://www.scmp.com/article/991004/vietnams-military-growth-raising-eyebrows-region (Accessed, October 15, 2013)

${ }^{282}$ Hong, Nong, UNCLOS and Ocean Dispute Settlement: Law and Politics in the South China Sea (New York: Routledge, 2012), Pg. 25 
warships and about 40-60 naval vessels and submarines. ${ }^{283}$ It is reported that "a fast patrol boat and a troop carrier were completed by a shipyard at Haiphong in September and October” of $2012 .^{284}$

While few details exist about Vietnam's military doctrines, it appears that its acquisitions program indicates a similar approach to the one taken by the PLA. In essence, it might be pursuing an A2/AD against China in regards to the SCS. Due to the fact that China borders the SCS and possesses military capabilities far exceeding those of its Southeast Asian neighbors, Vietnam may find it difficult to put such a stratagem in play. However, a modernized and capable VPA could present a credible enough force to deter further encroachment into the SCS by China, or at the very least safeguard its current possessions in the Spratlys. Considering that China's own SLOC must pass through Vietnam’s periphery, it may be a viable strategy to pursue.

\section{Japan-Vietnamese Relations}

Like many Southeast Asian countries, Vietnam endured Japanese Imperial occupation during WWII. However, since the 1973 when the Japanese officially recognized the Democratic Republic of Vietnam (DRVN), the government that would eventually reunify the country in 1976, the two sides have enjoyed relatively stable relations. Japan has been a top trading partner with Vietnam since the 1970s. By 1976 Japan had become the SRV's second largest trading partner after the Soviet Union. ${ }^{285}$

\footnotetext{
${ }^{283}$ Ibid.

${ }^{284}$ Todore, Greg, "Vietnam's Military Growth Raising Eyebrows in the Region," South China Morning Post, 2012, http://www.scmp.com/article/991004/vietnams-military-growth-raising-eyebrows-region (Accessed, October 15, 2013)

${ }^{285}$ Shiraishi, Masaya, Japanese Relations with Vietnam, 1951-1987 (Southeast Asia Program Publications: 1990), Pg. 45 \& 53.
} 
Japan became the largest contributor of foreign aid to the new Vietnamese government outside of the communist bloc; this aid took the form of grants that were essentially war reparations to the SRV. ${ }^{286}$

Today Japan continues to be a major trading partner of the SRV. As of 2012, Japan is the second largest export partner at $11.8 \%$ and third largest import partner at $10.4 \%$ of Vietnam. ${ }^{287}$ In 2009 the two countries signed the "Agreement Between Japan and the Socialist Republic of Viet Nam for an Economic Partnership." ${ }^{288}$ The trade agreement is expected to lower tariffs and promote economic cooperation between the two countries. ${ }^{289}$ Economic cooperation could deepen in the energy field as well. In an effort to increase LNG imports, Vietnam has sought assistance from the Tokyo Gas Company "to develop the Thi Vai LNG terminal in the Vung Tau province." 290 Japan has also agreed to aid Vietnam in developing a nuclear energy industry. In 2011 the "JapanViet Nam Nuclear Cooperation Agreement” came into force. This would be a mutually beneficial venture as Japan possesses expertise in nuclear reactor design and maintenance,

\footnotetext{
${ }^{286}$ Ibid. 55

287 "Vietnam,” The CIA World Factbook, https://www.cia.gov/library/publications/the-world-factbook/geos/vm.html (Accessed, September 12, 2013)

288 "Joint Press Statement on the Occasion of the entry into force of the Agreement between Japan and the Socialist Republic of Viet Nam for an Economic Partnership,” Ministry of Foreign Affairs of Japan, 2009, http://www.mofa.go.jp/region/asiapaci/vietnam/epa0910/joint.html (Accessed September 12, 2013)

289 “Agreement between Japan and the Socialist Republic of Viet Nam for an Economic Partnership,” Ministry of Foreign Affairs of Japan, 2009, Pg. 7, http://www.mofa.go.jp/region/asia-paci/vietnam/epa0812/agreement.pdf (Accessed September 12, 2013)

290 “Vietnam: Overview/Data,” Energy Information Administration, 2013, http://www.eia.gov/countries/country-data.cfm?fips=vm (Accessed November 3, 2013)
} 
allowing Vietnam to export more of its oil and natural gas resources in order to increase its GDP. ${ }^{291}$

In addition to the growing economic ties, much progress has also been achieved in the security sphere. Mutual concerns over China's assertive posture on the ECS and SCS have brought both countries closer in discussions over the security of the SLOC and the territorial disputes they have with China in their respective areas. In a 2011 meeting between former Japanese "Defense Minister Yasuo Ichikawa and his Vietnamese counterpart, Phung Quang Thanh,” the two sides “signed Memorandum on Defense Cooperation and Exchange." ${ }^{292}$ During the summit Ichikawa told Thanh that "The relationship between Japan and Vietnam [had] entered a new stage of development” and that Vietnam was a "strategic partner for peace and stability in Asia, and we want to deepen our partnership."293 Under the provisions of this memorandum the JSDF and the VPA will conduct military exchanges and Vice-Minister-level officials from each country will have regular dialogue. ${ }^{294}$

As with the Philippines, the Japanese have indicated that they are interested in providing Vietnam coast guard patrol vessels. In a 2013 summit Japanese Prime Minister Abe and Vietnamese Prime Minister Nguyen Tan Dung discussed their concerns over

\footnotetext{
291 "Notification for the Entry into Force of the Japan-Viet-Nam Nuclear Cooperation Agreement," Ministry of Foreign Affairs of Japan, 2011, http://www.mofa.go.jp/announce/announce/2011/12/1222_02.html (Accessed September 20, 2013)

${ }^{292}$ Kurashige, Nanae, “Japan, Vietnam Agree on Defense Cooperation,” The Asahi Shimbun, 2011, http://ajw.asahi.com/article/behind_news/politics/aj2011102515718 (Accessed September 20, 2013)

${ }^{293}$ Ibid.

${ }^{294}$ Ibid.
} 
maritime peace and stability, particularly the SCS. ${ }^{295}$ Prime Minister Abe chose Vietnam as his first destination after taking office, indicating the importance of Vietnam as a strategic partner for Japan in the region. In a sign of reciprocity the Vietnamese invited Japanese Defense Minister Itsunori Onodera to visit the naval facilities in Cam Ranh Bay. According to the Vietnamese, Onodera was the first foreign defense or military related official to ever be invited at the base. ${ }^{296}$ In a conference after his visit to the naval base, Onodera was asked about future security cooperation with the Vietnamese. He indicated that the two countries had been performing field exercises in diving medicine; furthermore, there were future exercises scheduled that would concentrate on submarine rescue. ${ }^{297}$ Since the Kilo-class submarines are the first significant submarines that Vietnam has operated, Japans' assistance in this area is considered vital.

As Vietnam's military modernizes it may look increasingly to Japan as a source of hardware and training. China's substantial marine mine inventory could prompt the Vietnamese to purchase MCM vessels from Japan, while simultaneously securing training from one of the most capable MCM forces in the world. This particular arrangement would not contravene Japan's strict weapons trade guidelines since these vessels do not have offensive capabilities. In a more challenging prospect, former Japanese Defense Minister Toshimi Kitazawa pointed out that Vietnam may be among the countries to which Japan would allow the sale of its state of the art diesel

\footnotetext{
295 “Japan-Viet Nam Summit Meeting,” Ministry of Foreign Affairs of Japan, 2013, http://www.mofa.go.jp/region/page23e_000033.html (Accessed October 1, 2013)

${ }^{296}$ Onodera, Itsunori, “Extra Press Conference by the Defense Minister,” Ministry of Defense, 2013, http://www.mod.go.jp/e/pressconf/2013/09/130917.html (Accessed October 1, 2013)

${ }^{297}$ Ibid.
} 
submarines. ${ }^{298}$ Although no further official statements have been made in regards to this subject, should conditions in the ECS and SCS continue to deteriorate, Japan could be prompted to remove even more restrictions on its military transfer guidelines.

\section{Chapter VI: Conclusion}

\section{Japan and Southeast Asia}

Although Japan has been more politically active in Southeast Asia in recent years as a result of its fear of growing Chinese influence, it remains restricted in large part by its constitution. That being said, amending Article IX of the Japanese constitution may not be necessary for Japan to play a more proactive security role in its own backyard. If Japan were able to participate in collective security agreements it would most likely only sign one with the United States. The fact is that creating any collective security agreement with a third party would have to involve the United States and would only escalate the existing tensions with China. If Japan were to sign collective security agreements with China's neighboring countries it would all but confirm Chinese fears of a U.S.-Japan strategy of encirclement and containment. Therefore, a more proactive Japan does not necessarily mean military security guarantees to its Southeast Asian neighbors, but rather a clear alternative to China by providing political and material support.

By pursuing deeper economic integration and relaxing its weapons export guidelines Japan can position itself as a credible strategic partner to Southeast Asian countries. Through its ODA programs Japan would be able to subsidize weapon

\footnotetext{
${ }^{298}$ Fackler, Martin, “Japan is Flexing its Military Muscle to Counter Rising China,” The New York Times, November 26, 2012, http://www.nytimes.com/2012/11/27/world/asia/japan-expands-its-regional-militaryrole.html?pagewanted=all (Accessed September 20, 2013)
} 
purchases of China's smaller neighbors in the same manner it has done for the Philippines with the provision of coast guard vessels. By facilitating military capacity building in the Philippines and Vietnam, Japan would be assisting these countries in their efforts to build a minimum credible defense against growing Chinese capabilities and therefore make sure that its SLOC is not completely dominated by the PLA. At the same time, by limiting its agreements to economic and capacity building, Japan can ensure that it does not become a party to an armed conflict in the SCS unless it chooses to do so on its own terms.

\section{China and Japan: Growing Enmity}

Despite significant economic interdependence between China and Japan, a pattern of growing enmity has emerged in recent years. Mutual suspicion between the two powers in the East Asian RSC have fostered an environment of rising nationalism and increasing securitization language towards each other. China's military modernization has done much to give an impetus to Japan's normalization process. Japanese Prime Minister Shinzo Abe ran on a nationalist campaign and on a promise to be tougher on China. Japanese leaders perceive that China's increasingly assertive stance in its territorial disputes is a result of the substantial military expenditures of the PRC as well as the patriotic education to which Chinese students are exposed. In the 2014 World Economic Forum at Davos, Abe explicitly stated that he perceived China’s 10\% annual increases in defense spending as a provocation. He further indicated that a reduction of tensions between the two countries would not occur so long as China continued its military build-up. The Prime Minister went as far as likening Sino-Japanese relations to 
that of Germany and Great Britain on the eve of World War I; explaining that despite deep economic ties the two countries ultimately went to war with each other. ${ }^{299}$

Abe's confrontational approach towards China appears to be informed by his belief that the Chinese educational system is essentially “anti-Japanese.” He believes that the emphasis on patriotic education in China creates a "'deeply ingrained' need to spar with Japan and other Asian neighbors over territory. This is due to the fact that the ruling Communist Party uses the disputes to maintain strong domestic support.”300 Abe, who enjoys a 71\% approval rating in his home country, has promised to make revisions to the pacifist constitution and increase the defense budget. Thus far he has delivered on defense spending. In 2013 he approved the first defense budget increase in 11 years. The JSDF and the JCG will receive a $0.8 \%$ and a $1.9 \%$ increase respectively. ${ }^{301}$ In that same year Abe’s cabinet promulgated Japan’s first ever national security strategy (NSS). The document explicitly identified China as a potential threat; stating that:

"China has been rapidly advancing its military capabilities in a wide range of areas through its continued increase in its military budget without sufficient transparency. In addition, China has taken actions that can be regarded as attempts to change the status quo by coercion based on their own assertions, which are incompatible with the existing order of international law, in the maritime and aerial domains, including the East China Sea and the South China Sea. In particular, China has rapidly expanded and intensified its activities in the seas and airspace around Japan, including intrusion into Japan's territorial waters and airspace around the Senkaku Islands. Moreover, China has shown the move

299 Yueh, Linda, “Japanese Prime Minister Shinzo Abe Urges Asia Military Restraint,” BBS News Asia, 2014, http://www.bbc.co.uk/news/world-asia-25851960 (Accessed, January 23, 2013)

${ }^{300}$ Harlan, Chico, “Japan’s Prime Minister Shinzo Abe: Chinese Need for Conflict is 'Deeply Ingrained,’” The Washington Post, 2013, http://www.washingtonpost.com/world/japans-prime-ministershinzo-abe-chinese-need-for-conflict-is-deeply-ingrained/2013/02/20/48adbc80-7a87-11e2-9a75dab0201670da_story.html (Accessed September 20, 2013)

${ }^{301}$ Reynolds, Isabel, “Japan Defense Budget to Increase for First Time in 11 Years,” Bloomberg, 2013, http://www.bloomberg.com/news/2013-01-29/japan-s-defense-spending-toincrease-for-first-time-in-11-years.html (Accessed October 1, 2013) 
that appears to unduly infringe the freedom of overflight above the high seas by establishing its own “Air Defense Identification Zone” over the East China Sea.”302

The document also calls for strengthening the unity of ASEAN and promotes progress towards the formulation of a CoC in the SCS. Furthermore, the reinforcement of the U.S.Japan alliance is viewed as a key priority to maintaining peace and security in the region..$^{303}$

Chinese officials have responded in kind. They see Japanese military normalization as a dangerous development and often equate it with a return to militarism and fascism. In response to a recent visit to the controversial Yasukuni Shrine by Prime Minister Abe, Chinese Foreign Ministry Spokeswoman Hua Chunying commented that the visit was proof of lingering militarism in Japan, declaring that "militarist aggression is the darkest demon in the country's history. Japan will truly regain trust from its Asian neighbors and the international society only if it dares to face and beat the demon in its history and its mind, or it will remain in the dock of history. ${ }^{304}$ Chinese Foreign Minister, Wang Yi echoed Mrs. Hua's statements by saying that the Yasukuni Shrine was a "symbol of Japanese militarism." The minister also stated that the world "should never allow fascist and militarist ideas to revive themselves in any shape or form." ${ }^{305}$ The reference to Japan’s imperialist period was implicit.

\footnotetext{
302 “National Security Strategy,” Kantei, 2013, Pg. 12-13, http://www.kantei.go.jp/foreign/96_abe/documents/2013/_icsFiles/afieldfile/2013/12/18/NSS.pdf (Accessed December 22, 2013)

${ }^{303}$ Ibid. Pg. 20-24

${ }^{304}$ Li Xiaokun and Ren Qi, “Tokyo Urged to End Militarism,” China Daily USA, 2014, http://usa.chinadaily.com.cn/world/2014-01/08/content_17221802.htm (Accessed, January 5, 2013)

${ }^{305}$ Browne, Andrew, “China Criticizes Japanese Leader's Visit to a War Memorial,” The Wall Street Journal, 2014, http://online.wsj.com/news/articles/SB10001424052702303448204579340831650070194
} 
Tokyo’s recent military budget increases and actions in Southeast Asia have also been a concern for Beijing. In response to Japan’s NSS, state-run Xinhua published an article declaring that Japan's new role as a "proactive contributor to peace" is merely a "phony coat" to "conceal Japan's wild ambition to become a military power." ${ }^{306}$ The authors claim that "in military terms, being "proactive" means acting proactively or even

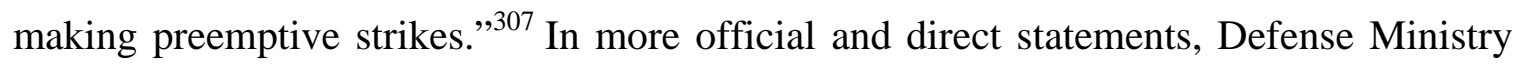
spokesman Geng Yansheng said that “China is firmly opposed to Japan’s relevant actions,” referring to Japan’s NSS. ${ }^{308}$ Spokesman Geng claimed that Japan was playing up “China’s military threat” and that this would increase regional tensions. He went on to express that:

"On the one hand, Japan claimed that it is a peace-loving country, and that it adheres to a defensive defense policy and will not be a military power. On the other hand, Japan is peddling the so-called "proactive pacifism."

On the one hand, Japan claimed that it respects freedom, democracy, human rights and the rule of law, but on the other hand, it repeatedly denied its history of aggression during the Second World War, challenged the post-war international order and hurt the feeling of the people of the war-victim countries.

Japan has on the one hand claimed to strengthen international coordination, safeguard peace and stability in the Asia-Pacific region, and make efforts to ensure security and prosperity of the international community, but on the other hand it sticked to the Cold War mentality and beefed up military alliance with relevant countries.”309

(Accessed January, 2014)

${ }^{306}$ Zhu Chao and Feng Wuyong, “’Abe-Military’ on State, Region on Alert,” Xinhua, 2013, http://news.xinhuanet.com/english/world/2013-12/17/c_125875313.htm (Accessed December 22, 2013)

${ }^{307}$ Ibid.

${ }^{308}$ Xuequan, Mu, “Chinese Military Lashes Out at Japanese Defense Documents,” Xinhua, 2013, http://news.xinhuanet.com/english/china/2013-12/21/c_125893931.htm (Accessed December 22, 2013)

${ }^{309}$ Ibid. 
The spokesman also noted that Japan has been proactively wooing other countries in order to create regional confrontation and roil the regional situation. ${ }^{310}$ Japan's defense cooperation agreements with a number of ASEAN countries serve as the basis for this belief.

Using more provocative language, PLA Air Force Colonel, Dai Xu, called on China to wage a short and decisive war against one of the claimants in SCS or Japan. He argued that a border clash like the 1962 war with India would deliver long-term peace. Col. Dai claims that U.S. support for its allies is weak and that China should call this bluff and "respond to these empty provocations with something real." ${ }^{311}$ Dai called Vietnam, the Philippines, and Japan, America’s running dogs in Asia, adding that "we only need to kill one, and it will immediately bring the others to heel." ${ }^{312}$

This escalation of inflammatory rhetoric between the two countries directly impacts the security of the region. Japan sees China's assertiveness on security matters as a threat to its national interests. This inevitably leads Japan to conduct balancing actions in the form of economic and defense cooperation agreements with Southeast Asian countries who share Japan's concerns about China. On the other hand, Beijing sees Tokyo's actions as a move towards militarism and as a containment strategy that aims to encircle China with pro-U.S.-Japan ASEAN members. This results in patterns of growing enmity which consequently lead to deteriorating bilateral relations and increased tensions.

\footnotetext{
${ }^{310}$ Ibid.

${ }^{311}$ Lague, David, “China’s Hawks Take the Offensive,” Reuters, 2013, http://www.reuters.com/investigates/china-military/ (Accessed December 5, 2013) ${ }^{312}$ Ibid.
} 
As a result, the tense political environment has not been conducive to conflict resolution measures or cooperation on security matters.

\section{Securitizing China}

China's geographic centrality as well as its economic and political clout gives it inherent advantages in the East Asian RSC. All ASEAN members as well as Japan are intrinsically connected to China through economic interdependence as well as the security preoccupations of the rising power. Since China's economic reforms in the late 1970s every country in the region has benefitted from increased Chinese investments as well as market opportunities in the mainland. China's "charm offensive" of the early 2000s did much to build good-will among Southeast Asian countries which had been concerned with China’s aggressive SCS policy throughout the 1990s. However, events that have occurred in recent years have done a lot of damage to China's image in the region. A 2013 poll conducted by the Pew Research Center indicated that both Japan and the Philippines' (Vietnam was not polled) view China’s military power negatively. The poll showed that $96 \%$ of Japanese and 68\% of Philippine respondents considered China’s growing military power as a "bad thing" ${ }^{313}$ The same poll asked "how big are territorial disputes between China and your country?” to which $82 \%$ of Japanese and 90\% of Philippine respondents answered it was a "big problem.,314

The negative downturn in China's image has not gone unnoticed in Beijing. The Global Times, a pro-government publication, conducted its own poll and found similar

\footnotetext{
313 “America’s Global Image Remains More Positive than China’s,” Pew Research Center, 2013, http://www.pewglobal.org/2013/07/18/chapter-3-attitudes-toward-china/ (Accessed October 1, 2013)

${ }^{314}$ Ibid.
} 
results. The poll involved more than 14,400 respondents from 14 countries which included the U.S., Russia, Japan, India, Vietnam, and South Korea. ${ }^{315}$ The data showed "that the closer you are to China, the more likely you are to have a negative view of it. Some 25.4 percent of respondents from the neighboring countries said they like China, 10.6 percent lower than those from the non-neighboring countries."316 According to the poll some $29.4 \%$ describe China as "belligerent” and 28.1\% say it is “complicated." Only 13.3\% of the respondents thought of China as peaceful. Perhaps even more troubling was the fact that people from neighboring countries believed that their country would have a competitive or confrontational relationship with China within the next 10 years; indicating that China is viewed as a threat by the citizens of neighboring countries ${ }^{317}$

Regional tensions have recently spiked as a result of China's unilateral declaration of an air defense identification zone (ADIZ) in the ECS. This move has sparked fears among Southeast Asian countries that China may soon do the same in the SCS. The Chinese Defense Ministry has reinforced such fears by stating that it will “establish other air defense identification zones at an appropriate time after completing preparations. ${ }^{318}$ Due to the fact that neither Vietnam nor the Philippines possess the capabilities to deter China from adopting an ADIZ in the SCS, they find the prospect of a SCS ADIZ as a serious threat to their claims in the region. Philippine Foreign Secretary,

\footnotetext{
315 Bai Tiantian and Wen Ya, “Arrogant or Confident?” Global Times, 2013, http://www.globaltimes.cn/content/831108.shtml\#.UvGb_ldViZ (Accessed December 20, 2013)

316 Ibid.

${ }^{317}$ Ibid.

${ }^{318}$ Heydarian, Richard Javad, “ADIZ Stirs Fears for South China Sea,” Asia Times, 2013, http://www.atimes.com/atimes/Southeast_Asia/SEA-01-061213.html (Accessed December 20, 2013)
} 
Albert Del Rosario, has stated that a SCS ADIZ presents the threat that "China will control the air space [in the South China Sea] ... It transforms an entire air zone into China's domestic air space." ${ }^{\text {319 }}$

Philippine President Aquino has be one of the staunchest critics of China since taking office. In a 2014 interview he made an international plea by asking the nations around the world to support the Philippines in resisting China's assertive claims in the SCS. He likened the situation of his country to that of Czechoslovakia in the late 1930s when the West accepted Germany’s demands for the Sudetenland. He stated: "If we say yes to something we believe is wrong now, what guarantee is there that the wrong will not be further exacerbated down the line?”320 He went on to say: “At what point do you say, 'Enough is enough'? Well, the world has to say it - remember that the Sudetenland was given in an attempt to appease Hitler to prevent World War II.”321 His remarks are indicative of his country's concerns for China's military buildup in the SCS. These remarks could have been fueled by reports from China that the PLA has drawn up plans to seize Thitu Island from the Philippines in 2014. The report said that "there will be no invasion into Filipino territories,” negating Philippine sovereignty claims to the island and that "the battle is aimed at recovery of the island stolen by the Philippines from China.,322

\footnotetext{
${ }^{319}$ Ibid.

${ }^{320}$ Bradsher, Keith, "Philippine Leader Sounds Alarm on China,” The New York Times, 2014, http://www.nytimes.com/2014/02/05/world/asia/philippine-leader-urges-international-help-inresisting-chinas-sea-claims.html?_r=0 (Accessed February 5, 2013)

321 Ibid.

${ }^{322}$ Lee-Brago, Pia, “China Preparing to Seize Pag-asa Island,” The Philippine Star, 2014,
} 
Access to vital oil and marine resources has also been an area where China's actions have elevated tensions in the region. China's recent efforts to develop oil and gas in contested territory have led to condemnation from the Vietnamese who see China's actions in the vicinity of the Paracels as illegal. Vietnamese Foreign Ministry Spokesman Luong Thanh Nghi asked China to “cease all activities that violate Vietnam’s sovereignty." ${ }^{323}$ This could be a growing problem for the Vietnamese who have experienced Chinese interference while conducting their own oil and gas surveys. China has also demanded that the Philippines cease giving out contracts to oil companies in the Spratly archipelago as it considers these territories its own. These events directly affect Vietnamese and Philippine energy security and have the potential to lead to further clashes between the claimants.

China's unilateral imposition of fishing bans in the SCS has also met deep criticism from Vietnam and the Philippines whose economies and population are heavily reliant on the fishing industry. The most recent ban took effect on January 1, 2014 and obliges foreign fishing vessels to obtain approval before entering waters which the local Hainan government says are under its jurisdiction. There were instantaneous responses from Vietnam and the Philippines regarding the ban. Vietnamese Foreign Ministry Spokesman Luong Thanh Nghi called the new ban

“illegal and invalid" and seriously violate Vietnam's sovereignty over the Hoang Sa (Paracels) and Truong Sa (Spratlys) islands. "Vietnam demands that China abolish the

http://www.philstar.com/headlines/2014/01/14/1278584/china-preparing-seize-pag-asa-islandreport(Accessed January 18, 2013)

323 “Vietnam Says Cnooc’s South China Sea Bids Violate Territory,” Bloomberg Businessweek, 2012, http://www.businessweek.com/news/2012-03-16/vietnam-says-cnooc-s-south-china-sea-bidsviolate-territory (Accessed September 12, 2013) 
above said wrongful acts, and practically contribute to the maintenance of peace and stability in the region,"324

Furthermore, Philippine Defense Secretary Voltaire Gazmin was quoted saying that “China is projecting itself as a superpower, they have been aggressive lately.” In addition, he stated that "we are not following the rules of China in our own territory, why are we going to follow them if we fish in our own seas.” ${ }^{325}$ Defiance by Vietnam and the Philippines may lead to maritime clashes considering the fact that China has routinely seized or harassed fishing vessels from both of these countries.

Heightened tensions and an increasingly negative opinion of China in the region have led to more frequent use of securitizing language aimed at China by Japan, Vietnam, and the Philippines. This indicates that the PRC is quickly becoming the primary security concern among key East Asian RSC countries. Consequently, many of the smaller states in the region have sought to balance China's influence and power with that of the United States and its primary ally in the region, Japan. America's pivot to the region has been generally welcomed by ASEAN states who have sought to reduce their exposure to China. ${ }^{326}$ At the same time, countries like the Philippines and Vietnam are exploring the possibility of allowing the U.S. greater access to their naval facilities as a way to hedge

\footnotetext{
${ }^{324}$ Dian, An, "Vietnam Dismisses China’s Fishing Curbs," Thanh Nien News, 2014, http://www.thanhniennews.com/index/pages/20140109-516-chinese-fishing-boats-violatedvietnamese-waters-in-2013.aspx (Accessed January 18, 2013)

${ }^{325}$ Lozada, Bong, “Gazmin Calls on Superpowers to Stand up to China,” Philippine Daily Inquirer, 2014, http://globalnation.inquirer.net/96905/gazmin-calls-on-superpowers-to-stand-up-to-china (Accessed January 18, 2014)

${ }^{326}$ Emmerson, Donald K., "Challenging ASEAN: The American Pivot in Southeast Asia," East Asia Forum, 2013, http://www.eastasiaforum.org/2013/01/13/challenging-asean-the-american-pivot-in-southeast-asia/ (Accessed, October 1, 2013)
} 
against China. ${ }^{327}$ As a key ally of the U.S. and as power in its own right, Japan has also been garnering support among ASEAN states in its efforts to maintain freedom of navigation in the region. Japan is increasingly being seen as another possible hedge vis-àvis China by Southeast Asian states who share Japan's concerns about China’s growing military capabilities and its implications for the freedom of navigation in the SCS. ${ }^{328}$

\section{De-securitizing Japan}

Japan has had a tumultuous history with most countries in the East Asian RSC as a result of its actions during WWII. Brutal occupation of most of its neighbors and perceived inadequate apologies for the atrocities it committed have been a serious thorn in Japan's relations with its neighbors, particularly China and the two Koreas. Although the issue of its WWII legacy continue to plague Japan's bilateral relations with China and the Koreas, ASEAN countries have been more forgiving. In 2008 the Ministry of Foreign Affairs of Japan (MOFA) commissioned TNS, a Singapore-based market research company, to conduct an opinion poll in Indonesia, Malaysia, Philippines, Singapore, Thailand, and Vietnam regarding Japan. When asked if Japan was a trustworthy friend for ASEAN countries, 90\% or more of the respondents from all six countries answered yes. ${ }^{329}$ When asked about what they presently thought about Japan's acts during WWII,

\footnotetext{
${ }^{327}$ Whitlock, Craig, "U.S. Eyes Return to Some Southeast Asia Military Bases,” The Washington Post, 2012, http://www.washingtonpost.com/world/national-security/us-seeks-return-to-se-asianbases/2012/06/22/gJQAKP83vV_story.html (Accessed October 1, 2013)

${ }^{328}$ Nguyen, Phuong, “Japan’s Pivot Should be Sustained: View from Southeast Asia,” cogitASIA: CSIS Asia House, 2013, http://cogitasia.com/japans-pivot-should-be-sustained-view-from-southeast-asia/ (Accessed October 5, 2013)

${ }^{329}$ Opinion Poll on Japan in Six ASEAN Countries,” Ministry of Foreign Affairs of Japan, 2008, Pg. 3, http://www.mofa.go.jp/region/asia-paci/asean/survey/qa0803.pdf (Accessed November 18, 2013)
} 
$59 \%$ and or more of the people surveyed in all six countries said that while Japan did some bad things, it was not an issue now. ${ }^{330}$ A Pew Research Center Poll in 2013 reinforced the 2008 findings showing ASEAN countries that were surveyed have a $78 \%$ or more favorable view of Japan (again, Vietnam was not polled). ${ }^{331}$

Japan's image has been slowly repaired in Southeast Asia as a result of its generous ODA packages to ASEAN member countries. Its soft power has also been on the rise due to its constructive participation in the Timor-Leste and Cambodian Peace Keeping Operations as well as its disaster relief assistance to countries struck by natural disasters. In the wake of the 2004 Tsunami Japan provided a total of $\$ 697$ million to the affected countries, almost double of China’s \$379 million contribution. Indonesia and Sri Lanka would receive the largest aid package at \$250 million and \$175 million respectively. ${ }^{332}$ In response to the 2013 Haiyan Typhoon which devastated the Philippines, the Japanese government pledged \$30 million and deployed it largest-ever relief effort overseas. A Japanese flotilla of three vessels made up of a cruiser, a cargo ship, a fuel supply ship and eight helicopters was supplemented by 1,000 JSDF troops on Philippine soil. ${ }^{333}$ In a December summit between Prime Minister Abe and President Aquino that year, Japan raised its contribution for emergency relief in the Philippines to

${ }^{330}$ Ibid. Pg. 13

331 “Japanese Public’s Mood Rebounding, Abe highly Popular,” Pew Research Center, 2013, http://www.pewglobal.org/2013/07/11/japanese-publics-mood-rebounding-abe-strongly-popular/ (Accessed October 1, 2013)

${ }^{332}$ Sisira Jayasuriya and Peter McCawley, The Asian Tsunami: Aid and Reconstruction After a Disaster (Cheltenham: Asian Development Bank Institute and Edward Elgar Publishing 2010), Pg. 46

${ }^{333}$ Mitsuru Obe, Yuka Hayashi and Alexander Martin, “Japan Deploys Self Defense Forces to Aid Philippines,” The Wall Street journal, 2013, http://online.wsj.com/news/articles/SB10001424052702303653004579209830690172474 (Accessed December 1, 2013) 
\$56.1 million. ${ }^{334}$ This was a major upset for Beijing which endured worldwide criticism for its initial $\$ 100,000$ offering. After international condemnation China pledged an additional \$1.6 million and deployed a medical relief ship with a 51-person medical team to assist in the Philippines. ${ }^{335}$

As previously mentioned, Japan has been critical in the provision of capacity building for coast guards in Southeast Asia. It has provided funds and training for many in the region in order to promote safe navigation in the SCS and continues to encourage information sharing about vessels and individuals suspected of committing piracy and armed robbery in the high seas. ${ }^{336}$ Japan has also been mediator for the Mindanao Peace Process between the Philippines and the Moro Liberation Front (MILF). The MILF is one the strongest Islamic separatist groups in the south of the Philippines and has fought the central government for years in order to establish an independent country. In 2012 Japan successfully negotiated a framework between the two sides in which they agreed to work towards a peace settlement that would eventually lead to the creation of the Autonomous Region in Muslim Mindanao (ARMM). ${ }^{337}$ In 2013 Prime Minister Abe reaffirmed Japan’s commitment to the Mindanao Peace Process and pledged "\$2 million of emergency grant aid for the internally-displaced persons arising from the armed conflict

\footnotetext{
334 “Japan-Philippines Summit Meeting, December 13, 2013” Ministry of Foreign Affairs of Japan, 2013, http://www.mofa.go.jp/region/page22e_000048.html (Accessed December 20, 2013)

${ }^{335}$ Ibid.

${ }^{336}$ Sato, Yoichiro, “Southeast Asian Receptiveness to Japanese Maritime Security Cooperation,” Asia-Pacific Center for Security Studies, 2007, http://www.apcss.org/Publications/Maritime\%20security\%20cooperation\%20JapanSE\%20Asia\%20Sato.pdf (Accessed, October 12, 2013)

337 "The Framework Agreement Concerning the Mindanao Peace Process,” Ministry of Foreign Affairs of Japan, 2012, http://www.mofa.go.jp/announce/announce/2012/10/1007_01.html (Accessed November 10, 2013)
} 
in Zamboanga City, Mindanao Island. ${ }^{, 338}$ Additionally, in its efforts to promote stability in Southeast Asia, for the first time since WWII, Japan provided military aid to a foreign country in 2012 when it approved a \$2 million package for its military engineers to train Cambodian and Timor-Leste troops in disaster relief and road building. ${ }^{339}$

Decades of investments, ODA, maritime cooperation, and peacekeeping operations in the region have effectively de-securitized Japan for many of the ASEAN states. This is in contrast to China which while continuing to enjoy the position of top trading partner for most ASEAN members, has increasingly been securitized by many in the region; a development that Japan has been eager to exploit. While economic ties between ASEAN and China continue to grow at a marked pace, and the United States continues to be the region's main stabilizing force and security provider, Japan is in a geostrategic position to fulfill both roles. Poor relations with China have prompted Japan to invest more of its money on ASEAN states. In 2013 Foreign Direct Investment (FDI) from Japan to China plunged by 37\% to $\$ 6.5$ billion. Meanwhile, FDI to Southeast Asia’s “four major economies - Indonesia, Malaysia, Thailand and the Philippines - surged by over $120 \%$ to almost $\$ 7.9$ billion.” 340 Tokyo has also expanded its currency swap

\footnotetext{
338 “Japan-Philippines Summit Meeting, October 13, 2013” Ministry of Foreign Affairs of Japan, 2013, http://www.mofa.go.jp/region/page23e_000006.html (Accessed November 10, 2013)

${ }^{339}$ Fackler, Martin, “Japan is Flexing its Military Muscle to Counter Rising China,” The New York Times, November 26, 2012, http://www.nytimes.com/2012/11/27/world/asia/japan-expands-its-regional-militaryrole.html?pagewanted=all (Accessed September 20, 2013)

${ }^{340}$ Schuman, Michael, “China and Japan May Not Like Each Other, but They Need Each Other,” Time, 2013, http://world.time.com/2013/12/01/china-and-japan-may-not-like-each-other-but-theyneed-each-other/ (Accessed December 5, 2013)
} 
agreements with a number of ASEAN countries in order to help stabilize financial markets in Asia. ${ }^{341}$

There are also signs that the normalization of the JSDF has not been considered a threat by Southeast Asian countries as it has been by China and South Korea. This is evident in the numerous defense cooperation agreements that Japan has concluded with many ASEAN states like Vietnam and the Philippines as well as Indonesia. In an interview with the Financial Times, Philippine Foreign Minister Albert Del Rosario said that his country was "looking for balancing factors in the region and Japan could be a significant balancing factor.” ${ }^{342}$ In a similar fashion, Indonesian Defense Minister Purnomo Yusgiantoro has publicly expressed support for Japan's plans to develop its armed forces, further indicating that many countries in the region are comfortable with Japan's efforts to play a more substantial role in the security of the East Asian RSC. ${ }^{343}$

\section{RSCT and Predictive Scenarios}

In RSCT, processes of securitization and desecuritization as well as patterns of amity and enmity link the actors in the region. ${ }^{344}$ The East Asian RSC certainly exhibits

\footnotetext{
${ }^{341}$ Nakamichi, Takashi, “Japan to Double Indonesia, Philippines Currency Swap Lines,” The Wall Street Journal, 2013, http://online.wsj.com/news/articles/SB10001424052702303497804579241554019250632 (Accessed December 12, 2013)

${ }^{342}$ Magdaraog Cordero, Jean, “Philippines Enhances Alliances with Japan, US,” Asia Pacific Defense Forum, 2012, http://apdforum.com/en_GB/article/rmiap/articles/online/features/2012/12/30/philippines-securityalliance (Accessed December 5, 2013)

343 Nguyen, Phuong, “Japan’s Pivot Should be Sustained: View from Southeast Asia,” cogitASIA: CSIS Asia House, 2013, http://cogitasia.com/japans-pivot-should-be-sustained-view-from-southeast-asia/ (Accessed October 5, 2013)

${ }^{344}$ Barry Buzan and Ole Waever, Regions and powers: The Structure of International Security (Cambridge: Cambridge University Press, 2003), Pg. 45
} 
these attributes. Economic, food, energy, and traditional security interdependence are traits which all states in the RSC share. Furthermore, historical friendships as well as bitter war legacies continue to inform the bilateral relations of many of the actors in the region. Given the information presented above, RSCT can be used to evaluate a number of different scenarios that demonstrate how the region could transform itself in the future which can in turn help predict how the SCS disputes will be resolved.

The emergence of the East Asian RSC was the result of a post-Cold War world. This Supercomplex was a great power bi-polar RSC where China became the militarypolitical center while Japan became the economic center. China's military-political significance stemmed from its long-standing links with Southeast Asian countries. ${ }^{345}$ It would be unable to play a major economic role in its early years as a result of its stillnascent economy. On the other hand, although Japan was experiencing an economic recession beginning with the 1990s it still remained the second largest economy in the world at the time. However, the historical legacy of its brutal occupation of numerous countries in the region during WWII prohibited the Japanese from playing a key militarypolitical role. The evolution of the Supercomplex and its many security concerns hinges on the domestic developments of the two great powers and the relationship between the two. The decade since the publication of Regions and Powers: The Structure of International Security has seen significant developments which allow for more concise predictions.

In the past decade China has become the second largest economy in the world, overtaking Japan, and has become the second largest military defense spender, behind the

${ }^{345}$ Ibid. Pg. 155-156 
United States. While economic reforms continue at a regular pace, political reforms have yet to materialize. China, at least for the foreseeable future, will continue to be governed by a one-party system. Quite significantly, China’s increased military capabilities have also allowed it to become more assertive in the territorial disputes with its neighbors. These developments have led to increased tensions in the ECS and the SCS where the disputes have led to clashes between China and Vietnam, the Philippines and Japan. As a result, China has become the primary security concern for many countries in the region. Although China will continue to enjoy deeper economic integration with neighboring countries, many of the smaller states are now looking at Japanese investment and security cooperation as a way to offset China's influence.

For its part, Japan has been gradually stepping out of nearly two decades of economic stagnation. It continues to be an economic power, ranked number 3 behind China and the United States. It also continues to have the most advanced military in the region, backed by the $5^{\text {th }}$ largest defense budget in the world. More significantly, its normalization process has been sped up in recent years as a result of a perceived "China threat.” Japan's citizens are now more supportive of the constitutional changes required to fully normalize the JSDF status and make Japan a normal power. A more politically active Japan has been pursuing its own aggressive policy in Southeast Asia by redoubling its economic investments in the region and concluding defense cooperation agreements with a number of Southeast Asian countries; particularly Vietnam and the Philippines which it considers its strategic partners for maintaining the freedom of navigation in the SCS. Japan has essentially taken advantage of the mounting fear among neighboring 
states that China's growing military power will have detrimental effects on their security and national interests.

The enmity between China and Japan, which had remained under the surface when the two powers normalized relations, has come to the forefront in recent years. Mutual suspicion and different interpretations of the events that occurred during WWII have plagued the dialogue between the two countries. Furthermore, statements and actions taken by officials from both countries have led to a serious deterioration in bilateral relations. This growing enmity between the two powers has security ramifications for the East Asia RSC. As dialogue and cooperation between the two polar centers in the RSC diminishes, it is unlikely that successful negotiations over disputed territory will occur. Far more likely, each will pursue strategic advantages over the other in all available fields. As previously mentioned, Japan has been apt to exploit China's political missteps in the region as a means to pursue a more active security policy.

Given the information provided, what does RSCT tell us about the evolution of the East Asian RSC? I suggest that there are two most likely scenarios, each giving a different conclusion to the SCS disputes. Although mindful that there are numerous possible outcomes to the evolution of the East Asian RSC, and thus the resolution of the SCS disputes, the following two scenarios appear to be the most likely.

\section{$\underline{\text { Scenario \#1 }}$}

Should Japan continue to 'normalize' and the U.S. Asian pivot fully materialize, the East Asian RSC will become a true bipolar great power RSC. I say 'true' because for the first decade of the $21^{\text {st }}$ century, the East Asian RSC was almost wholly centered on China due to America's preoccupation in the Middle East and Japan's domestic political 
instability. A bipolar Supercomplex in East Asia would have a legitimate counterweight to China's overwhelming geographical, economic, and growing military advantages. China's counterweight would essentially be the U.S.-Japan alliance. America's pivot to Asia would not be very effective without a more proactive Japanese military-political agenda. This is due to the fact that Japan shares geographic links to the region while the U.S., as a superpower, is spread across the globe with no real geographical presence in the East Asian RSC. Conversely, Japan cannot be a pole by itself due to the fact that it does not possess the demographic, economic, and military capability to project power at the same level that China can. Therefore, a truly balanced bipolar RSC in East Asia requires more proactive Japan willing to project beyond its borders as well as the U.S. fully committed to its Asian rebalance.

By creating a true second pole to China, ASEAN would be able to more effectively manage the SCS disputes by presenting a united front. This united front would be made possible by credible Japanese economic as well as military-political engagement in the region. In doing so, a $\mathrm{CoC}$ may be reached and pave the way for a more equitable resolution of the territorial disputes. China could be more successfully socialized within multilateral organizations and agreements to play a more constructive role in the security of the region. A process like this could eventually lead to the desecuritization of China among Southeast Asian countries and potentially lead to more significant integration.

This scenario clearly hinges on the continuation of stable domestic politics of the three powers involved. For this scenario to come to fruition the political establishment of Japan would have to avoid returning to the stagnating years of the post-Koizumi administration. So far this lesson appears to have been learned. This would ensure 
political stability and continued progress on the normalization process. In the U.S., politicians need to be fully committed to the Asian pivot and not be significantly distracted by other issues in another region. The fact of the matter is that short of another devastating financial crisis, the East Asia RSC is poised to continue being the most economically dynamic region in the world while possessing some of the most troublesome territorial disputes. Those factors alone necessitate serious American engagement in the region if it is to secure its interests there. For China the assumption is made that economic growth, while slowing down in recent years, will continue to be robust which would facilitate continued stability. Furthermore, Xi Jinping, the Chairman of the CCP and leader of the PRC, has managed to consolidate more power under his administration than any of his two previous counterparts were able to. ${ }^{346}$ The centralization of power around Chairman Xi Jinping should enable him to tackle the vast domestic challenges that China currently faces and therefore ensure China's continued economic and military growth.

\section{$\underline{\text { Scenario \#2 }}$}

However, if Japan is unable to normalize significantly enough to provide credible security engagement in the region, and the U.S. pivot is undermined, the most likely outcome is a unipolar centered RSC around China. Normalization in Japan needs to reach a level that allows it to project its security concerns beyond its immediate borders. If it fails to do so China will have more room to maneuver and pursue its own militarypolitical agenda independently of the concerns of its neighbors. Likewise, if the U.S. Asia

\footnotetext{
${ }^{346}$ Hatton, Celia, “China’s Xi Jinping: What Has He Achieved in His First Year,” BBC News China, 2014, http://www.bbc.com/news/world-asia-china-26463983 (Accessed March 30, 2014)
} 
pivot is undermined or is not perceived as credible, Japan will not be able to do much on its own even if it continues to normalize due to the fact that China enjoys geographic demographic, economic, and military advantages that Japan simply cannot match despite its economic and military prowess. This would mean that while Japan is completely capable of protecting its own territory, it would be unable to secure its SLOC on the SCS should the region evolve into a unipolar centered RSC.

This scenario may prove detrimental to the states contending with China over the SCS. It would all but ensure that any negotiations that take place to resolve the disputes would be done bilaterally, the way in which China has preferred to conduct them as its advantage as a regional power would diminish the bargaining power of smaller states. In this scenario ASEAN would be too disunited as American and Japanese economic and security guarantees would not be credible and member countries' exposure to China would heavily influence their policies. As a result, ASEAN would be unable to reach a unanimous consensus on the SCS and present a viable platform for negotiation. Therefore, the resolution of the SCS disputes would not occur on equitable grounds.

Again, this scenario assumes that China will continue to have a relatively stable domestic climate which is conducive to economic growth and increasing PLA capabilities. While JSDF power-projection capabilities may be growing, geography and demographics accord China with enough capacity to offset Japanese qualitative military advantages outside of its own territory. This means that Japanese SLOC in the SCS could be at risk without the aid and support of the American military. The U.S. military establishment is certainly aware of the potential threat that China poses to the freedom of navigation in the SCS and its interests in the region. This could at least guarantee that the 
Asian pivot receives significant attention in the political agenda of the U.S.; however, budget constraints and polarized domestic politics could derail the pivot.

\section{Moving Forward}

The situation in the SCS is an ongoing process that continues to evolve on an almost daily basis. It is clear that the two regional powers have interests in the SCS and are pursuing different strategies to meet their economic and security needs. China's military capability has allowed it to push Vietnam and the Philippines on these disputes, but as a consequence motivated them to internationalize the problem by attempting to bring in the U.S. and its main regional ally, Japan, to counter it. The Japanese, galvanized by a popular Prime Minister and motivated by growing tensions with China over the Senkaku/Diaoyu Islands, have been pursuing a more proactive policy in Southeast Asia in order to secure its SLOC and ensure that China's sweeping claims in the SCS do not come to fruition. It would not be in Japan's interest to see China control the SCS.

Although it is highly unlikely that Japan will forge mutual defense agreements with any other nation as a result of its ban on collective defense, it is positioning itself as a viable economic alternative to China and perhaps more importantly, as a provider of political support and military equipment and training. As a result of China's more assertive policies and its subsequent securitization by key states in the region, the prospects of productive negotiations seem unlikely. China, emboldened by its growing capabilities and American neutrality on the SCS disputes, continues to prefer bilateral negotiations. On the other hand, contending states, with Japan's explicit support, continue to advocate for a multilateral framework to resolve the disputes. 


\section{Further Research}

RSCT allows for some measure of prediction on how the region will evolve and how the disputes may be resolved in the coming years. However, due to its realist foundation, it does not adequately address the East Asian RSC pattern of increased economic interdependence with China while simultaneously securitizing it. A liberal or Institutionalist approach to studying this pattern may provide different conclusions on how the region may evolve and how the numerous ongoing territorial disputes could be resolved. Further research regarding the rising number of economic and trade agreements formed between China and its neighbors may provide insight to the growing economic interdependence in the region and its effects on the emergent number of international organizations in the region. By understanding the level of interdependence among countries in the area, it may be possible determine whether economic security and interdependence is sufficient for stronger regional integration, or whether traditional security concerns will continue to dominate the domestic agenda of China's neighboring states.

Another line of research that can be pursued is whether a proper conflict resolution mechanism can emerge in the East Asian RSC. It is clear that historical enmity between the two major powers and the increasing securitization of China among a number of states in the region serve as impediments to effective confidence building among neighboring states. Confidence building measures would be a prerequisite to instituting proper conflict resolution regimes. All parties to the numerous disputes in the region are aware that military conflict amongst them would not be beneficial. Therefore, reaching a certain level of confidence building would necessitate the de-escalation of 
securitization and nationalist rhetoric. This is particularly important in the case of some Southeast Asian countries towards China, Japan and S. Korea towards China, as well as China and the two Koreas towards Japan.

Examining the rising nationalist sentiment among the disputing countries may provide insightful information that would facilitate a better understanding on whether the ruling elites in these countries are capable of reducing nationalist rhetoric or has securitization language been so effectively disseminated that de-escalating would prove to be political suicide, or perhaps whether it's preferable to continue using it as a tool for securing domestic support. This line of research could allow researchers and analysts to ascertain whether confidence building measures are likely to develop, and therefore more likely to evolve into proper conflict resolution regimes, or whether mutual distrust and growing nationalism will continue to be an impediment to the formation of such regimes. 


\section{LIST OF REFERENCES}

“About: Ministry,” Ministry of Defense, http://www.mod.go.jp/e/about/index.html (Accessed April 12, 2013)

“Agreement between Japan and the Republic of the Philippines for an Economic Partnership,” Ministry of Foreign Affairs of Japan, 2006, http://www.mofa.go.jp/region/asia-paci/philippine/epa0609/main.pdf (Accessed, December 10, 2013)

"Agreement between Japan and the Socialist Republic of Viet Nam for an Economic Partnership,” Ministry of Foreign Affairs of Japan, 2009, http://www.mofa.go.jp/region/asia-paci/vietnam/epa0812/agreement.pdf (Accessed September 12, 2013)

“America’s Global Image Remains More Positive than China’s,” Pew Research Center, 2013, http://www.pewglobal.org/2013/07/18/chapter-3-attitudes-toward-china/ (Accessed October 1, 2013)

“Annual Report To Congress: Military Power of the People’s Republic of China 2007.” Department of Defense, 2007, http://www.defense.gov/pubs/pdfs/070523-chinamilitary-power-final.pdf (Accessed November 12, 2013)

"Annual Report To Congress: Military and Security Developments Involving the People's Republic of China 2011,” Department of Defense, 2011, http://www.defense.gov/pubs/pdfs/2011_CMPR_Final.pdf (Accessed November 10, 2013)

“China Starts Annual South China Sea Fishing Ban,” Xinhua, 2013, http://news.xinhuanet.com/english/china/2013-05/16/c_132386383.htm (Accessed September 12, 2013)

“Defense Posture Review Interim Report,” Ministry of Defense, 2013, http://www.mod.go.jp/j/approach/agenda/guideline/2013_chukan/gaiyou_e.pdf (Accessed October 13, 2013)

“Defense Programs and Budget of Japan: Overview of FY 2014 Budget Request,” Ministry of Defense, 2013, http://www.mod.go.jp/e/d_budget/pdf/251009.pdf (Accessed December 13, 2013)

“Digital Gazetteer of the Spratly Islands," The South China Sea, http://www.southchinasea.org/2011/08/19/digital-gazetteer-of-the-spratly-islands/ (Accessed December 12, 2013) 
"East Asia Pacific Economic Update, October 2013 - Rebuilding Policy Buffers and Reinvigorating Growth,”

The World Bank, 2013, http://www.worldbank.org/en/region/eap/publication/eastasia-pacific-economic-update-october-2013 (Accessed November 15, 2013)

"Fish Contribution to the Economy," Bureau of Fisheries and Aquatic Resources, http://www.bfar.da.gov.ph/pages/AboutUs/maintabs/stat-fishcontri_2011.html (Accessed December 5, 2013)

"Flashpoints: Security in East and South China Seas," Center for New American Security, http://www.cnas.org/flashpoints/timeline (Accessed December 5, 2013)

"Foreign Trade Statistics of the Philippines: First Semester 2012,"

National Statistics Office, 2012, http://www.census.gov.ph/content/foreign-trade-statistics-philippines-firstsemester-2012 (Accessed, December 10, 2013)

“Japan-Philippines Summit Meeting,” Ministry of Foreign Affairs of Japan, 2013, July 27, 2013, http://www.mofa.go.jp/region/page6e_000121.html

(Accessed, October 12, 2013)

“Japan-Philippines Summit Meeting, October 13, 2013”

Ministry of Foreign Affairs of Japan, 2013, http://www.mofa.go.jp/region/page23e_000006.html

(Accessed November 10, 2013)

"Japan-Philippines Joint Statement on the Comprehensive Promotion of the "Strategic Partnership" between Neighboring Countries Connected by Special Bonds of Friendship,” Kantei, 2011, http://www.kantei.go.jp/foreign/noda/diplomatic/201109/27philippines_e.html (Accessed October 12, 2013)

“Japan-Philippines Summit Meeting, December 13, 2013”

Ministry of Foreign Affairs of Japan, 2013, http://www.mofa.go.jp/region/page22e_000048.html

(Accessed December 20, 2013)

“Japan-Viet Nam Summit Meeting,” Ministry of Foreign Affairs of Japan, 2013, December 15, 2013, http://www.mofa.go.jp/region/page23e_000033.html (Accessed October 1, 2013)

“JMSDF Hyuga Class Destroyer, Japan,” Naval-Technology.com, http://www.naval-technology.com/projects/hyuga-class/

(Accessed April 12, 2013) 
"Joint Press Statement on the Occasion of the entry into force of the Agreement between Japan and the Socialist Republic of Viet Nam for an Economic Partnership,” Ministry of Foreign Affairs of Japan, 2009, http://www.mofa.go.jp/region/asiapaci/vietnam/epa0910/joint.html (Accessed September 12, 2013)

"More than the Sum of its Parts: Dutch SIGMA ships for Vietnam," Defense Industry Daily, 2013, http://www.defenseindustrydaily.com/more-than-the-sum-of-its-parts-dutchsigma-ships-for-vietnam-07173/ (Accessed December 5, 2013)

“National Security Strategy,” Kantei, 2013, http://www.kantei.go.jp/foreign/96_abe/documents/2013/_icsFiles/afieldfile/201 3/12/18/NSS.pdf (Accessed December 22, 2013)

"Notification for the Entry into Force of the Japan-Viet-Nam Nuclear Cooperation Agreement," Ministry of Foreign Affairs of Japan, 2011, http://www.mofa.go.jp/announce/announce/2011/12/1222_02.html (Accessed September 20, 2013)

"Opinion Poll on Japan in Six ASEAN Countries," Ministry of Foreign Affairs of Japan, 2008, http://www.mofa.go.jp/region/asia-paci/asean/survey/qa0803.pdf (Accessed November 18, 2013)

“Philippines, U.S. Eye Expansion of Joint Military Exercise,” Xinhua, 2013, http://news.xinhuanet.com/english/world/2013-04/17/c_132317138.htm (Accessed, October 5, 2013)

“SIPRI Military Expenditure Database”, Stockholm International Peace Research Institute, (2012), http://www.sipri.org/research/armaments/milex/research/armaments/milex/researc h/armaments/milex/milex_database (Accessed April 11, 2013)

“South China Sea,” Energy Information Administration, 2013, http://www.eia.gov/countries/regions-topics.cfm?fips=scs (Accessed December 20, 2013)

"Statement by the Chief Cabinet Secretary on Guidelines for Overseas Transfer of Defense Equipment etc.,” Kantei, 2011, http://www.kantei.go.jp/foreign/others/201112/_icsFiles/afieldfile/2012/01/31/2 0111227DANWA_e.pdf (Accessed December 5, 2013)

"Territorial Claims in the Spratly and Paracel Islands," Global Security, http://www.globalsecurity.org/military/world/war/spratly-claims.htm (Accessed September 20, 2013) 
"The Framework Agreement Concerning the Mindanao Peace Process,"

Ministry of Foreign Affairs of Japan, 2012, http://www.mofa.go.jp/announce/announce/2012/10/1007_01.html (Accessed November 20, 2013)

"The People's Liberation Army Navy: A Modern Navy with Chinese Characteristics," Office of Naval Intelligence, 2009, https://www.fas.org/irp/agency/oni/pla-navy.pdf (Accessed November 13, 2013)

“The Philippines,” CIA World Factbook, https://www.cia.gov/library/publications/the-world-factbook/geos/rp.html (Accessed December 12, 2013)

"The Stages in the Development of Vietnam Fisheries Sector," Directorate of Fisheries, 2012, http://www.fistenet.gov.vn/introduction/about-directorate-of-fisheries/history-offisheries-development (Accessed November 10, 2013)

"The world needs the Japan Self-Defense Forces (JSDF)," Ministry of Defense, 2011, http://www.mod.go.jp/e/publ/pamphlets/ (Accessed November 18, 2013)

"Towards a Self-Reliant Defense Force: A look into the AFP Modernization Law," National Defense College of the Philippines, 2013, http://www.ndcp.edu.ph/publications/6\%20GAUD\%20Towards\%20a\%20Self\%2 0Reliant\%20Defense\%20Force.pdf (Accessed September 11, 2013)

“Trade Registers,” Stockholm International Peace Research Institute, 2012, http://portal.sipri.org/publications/pages/transfer/trade-register (Accessed, October 15, 2013)

“US, Japan, Australia Plan South China Sea Drill,” Associated Free Press, 2011, http://www.google.com/hostednews/afp/article/ALeqM5ijF5kpgjM_4UmJeWA05Yu1sfKtg?docId=CNG.b25e50471bf7cd80f49ff0b9169e31d 7.121 (Accessed October 5, 2013)

"Vietnam," The CIA World Factbook, https://www.cia.gov/library/publications/the-world-factbook/geos/vm.html (Accessed, September 12, 2013)

“Vietnam: Overview/Data,” Energy Information Administration, 2013, http://www.eia.gov/countries/country-data.cfm?fips=vm (Accessed November 3, 2013) 
"Vietnam’s Fishery Products Export in the First 9 Months of 2012,"

Vietnam Trade Promotion Agency, 2012,

http://www.vietrade.gov.vn/en/index.php?option=com_content\&view=article\&id

=1622:-vietnams-fishery-products-export-in-the-first-9-months-of-

2012\&catid=270:vietnam-industry-news\&Itemid $=363$

(Accessed November 10, 2013)

"Vietnam Says Cnooc’s South China Sea Bids Violate Territory,"

Bloomberg Businessweek, 2012,

http://www.businessweek.com/news/2012-03-16/vietnam-says-cnooc-s-south-

china-sea-bids-violate-territory (Accessed September 12, 2013)

Amador III, Julio S., "The Philippines' Security Cooperation with the United States and Japan,” East-West Center, Asia Pacific Bulletin 227 (2013), http://www.eastwestcenter.org/sites/default/files/private/apb227.pdf (Accessed October 10, 2013)

Andrew S. Erikson, Lyle J. Goldstein, and William S. Murray, "Chinese Mine Warfare: A PLA Navy 'Assassin’s Mace’ Capability,” Naval War College, 2009, http://www.usnwc.edu/Research---Gaming/ChinaMaritime-Studies-Institute/Publications/documents/CMS3_Mine-Warfare.aspx (Accessed November 13, 2013)

Atanassova-Cornelis, Elena, "Political and Security Dynamics of Japan-China Relations: Strategic Mistrust, Fragile Stability and the US Factor,” Political Studies Association, 2010, 5, http://www.psa.ac.uk/Proceedings/2010 (Accessed November 10, 2013)

Bai Tiantian and Wen Ya, “Arrogant or Confident?” Global Times, 2013, http://www.globaltimes.cn/content/831108.shtml\#.UvGb_ldViZ (Accessed December 20, 2013)

Banlaoi, Rommel C., Philippines-China Security Relations: Current Issues and Emerging Concerns (Quezon City: Philippine Institute for Peace, Violence and Terrorism Research, 2012)

Barboza, David, "China Passes Japan as Second-Largest Economy,” The New York Times, August 15, 2010, http://www.nytimes.com/2010/08/16/business/global/16yuan.html?pagewanted=a Il (Accessed October 30, 2013) 
Ben Dolven and others, eds., "Maritime Territorial Disputes in East Asia:

Issues for Congress,” Congressional Research Service, 2013, http://www.fas.org/sgp/crs/row/R42930.pdf (Accessed September 12, 2013)

Bergsten, Fred C. et al., China's Rise: Challenges and Opportunities (Washington D.C.: The CSIS Press 2009)

Blanco Pitlo III, Lucio, “The Philippines and the West Philippine Sea,” The Diplomat, 2013, http://thediplomat.com/2013/10/the-philippines-and-the-west-philippine-sea/ (Accessed December 10, 2013)

Blasko, Dennis J. The Chinese Army Today: Tradition and Transformation for the $21^{\text {st }}$ Century (New York: Routledge 2012)

Bouchat, Clarence J., Dangerous Ground: The Spratly Islands and U.S. Interests and Approaches," U.S. Army War College Press, 2013, http://www.strategicstudiesinstitute.army.mil/pdffiles/PUB1187.pdf (Accessed November 10, 2013

Bradsher, Keith, "Philippine Leader Sounds Alarm on China," The New York Times, 2014, http://www.nytimes.com/2014/02/05/world/asia/philippine-leader-urgesinternational-help-in-resisting-chinas-sea-claims.html?_r=0 (Accessed February 5, 2013)

Browne, Andrew, "China Criticizes Japanese Leader's Visit to a War Memorial," The Wall Street Journal, 2014, http://online.wsj.com/news/articles/SB10001424052702303448204579340831650 070194 (Accessed January, 2014)

Bruzdzinski, Jason E., “Demystifying Shashoujian: China’s Assasin’s Mace Concept,” MITRE, 2005, http://www.mitre.org/publications/technical-papers/demystifying-shashoujianchinas-assassins-mace-concept (Accessed November 12, 2013)

Bonnie Glaser and Alison Szalwinski, "Second Thomas Shoal Likely the Next Flashpoint in South China Sea," The Jamestown Foundation China Brief 13 (2013), http://www.jamestown.org/uploads/media/cb_06_21.pdf (Accessed December 5, 2013) 
Burgess, J. Peter, "The Politics of the South China Sea: Territoriality and International Law,” Security Dialogue 34:1 (2003), http://community.middlebury.edu/ scs/docs/Burgess,\%20Politics\%20of\%20the\% 20South\%20China\%20Sea-Territoriality\%20and\%20.pdf (Accessed December 5, 2013)

Bush, Richard C. The Perils of Proximity: China-Japan Security Relations

(D.C.: Brookings Institution Press, 2010)

Buszynski, Leszek, "The South China Sea: Oil, Maritime Claims, and U.S.-China Strategic Rivalry,” The Washington Quarterly 35:2 (2012), https://csis.org/files/publication/twq12springbuszynski.pdf (Accessed November 3, 2013)

Buzan, Barry and Ole Waever, Regions and powers: The Structure of International Security (Cambridge: Cambridge University Press, 2003)

Cesar Z. Luna and others eds., "Profiling the Status of Philippine Marine Fisheries: A General Introduction and Overview," in In Turbulent Seas: The Status of Philippine Marine Fisheries (Manilla: Department of Agriculture:

Bureau of Fisheries and Aquatic Resources, 2004)

Chan, Minnie, "Major Development Plan for Woody Island Unveiled," South China Morning Post, 2014, http://www.scmp.com/news/china/article/1074996/major-development-planwoody-island-unveiled (Accessed January 29, 2013)

Chang, Amy. "Indigenous Weapons Development in China's Military Modernization." U.S.-China Economic and Security Review Commission Staff Research Report, 2012, http://www.uscc.gov/researchpapers/2012/China-Indigenous-MilitaryDevelopments-Final-Draft-03-April2012.pdf (Accessed November 12, 2013)

Clive Schofield and Ian Storey, The South China Sea Disputes: Increasing Stakes and Rising Tensions (Washington D.C.: The Jamestown Foundation, 2009)

Cordesman, Anthony, Yarosh, Nicolas S. "Chinese Military Modernization and Force Development: A Western Perspective.” Center for Strategic and International Studies, 2012, http://csis.org/publication/chinese-military-modernization-andforce-development-0 (Accessed November 11, 2013)

Cortez, Michael Angelo A., "Japan-Philippines Free Trade Agreement: Opportunities for the Movement of Workers," Ritsumeikan International Affairs 7 (2009), http://www.ritsumei.ac.jp/acd/re/k-rsc/ras/04_publications/ria_en/7_05.pdf (Accessed December 11, 2013) 
Cronin, Patrick M., China's Global Quest for Resources and Implication for the United States, " Center for a New American Security, 2012, http://www.cnas.org/files/documents/publications/CNAS\%20Testimony\%20Cron in\%20012612_1.pdf (Accessed December 20, 2013)

Dian, An, "Vietnam Dismisses China’s Fishing Curbs,” Thanh Nien News, 2014, http://www.thanhniennews.com/index/pages/20140109-516-chinese-fishingboats-violated-vietnamese-waters-in-2013.aspx (Accessed January 18, 2013)

Dawson, Chester, "Japan Lifts Decadeslong Ban on Export of Weapons," The Wall Street Journal, 2011, http://online.wsj.com/news/articles/SB10001424052970203479104577123710031 180408 (Accessed December 5, 2013)

Dizon, Nikko, PH, Japan Defense Chiefs Welcome Deepening Ties,” Philippine Daily Inquirer, 2013, http://globalnation.inquirer.net/78899/ph-japan-defense-chiefs-welcomedeepening-ties (Accessed October 5, 2013)

Dung, Nguyen Tan, "Shangi-La Dialogue 2013 Keynote Address," Shangri-La Dialogue: The IISS Asia Security Summit, 2013, http://www.iiss.org/en/events/shangri\%20la\%20dialogue/archive/shangri-ladialogue-2013-c890/opening-remarks-and-keynote-address-2f46/keynote-addressd176 (Accessed December 5, 2013)

Dutton, Peter, "Three Disputes and Three Objectives, China and the South China Sea," Naval War College Review (2011)

Easton, Ian, "China's Military Strategy in the Asia-Pacific: Implications for Regional Stability,” The Project 2049 Institute, 2013, http://www.project2049.net/documents/China_Military_Strategy_Easton.pdf (Accessed November 13, 2013)

Emma Chanlett-Avery and others, eds., "Sino-Japanese Relations: Issues for U.S. Policy, Congressional Research Service, 2008, https://www.fas.org/sgp/crs/row/R40093.pdf (Accessed September 20, 2013

Emmers, Ralf, Geopolitics and Maritime Territorial Disputes in East Asia (New York: Routledge, 2010)

Emmerson, Donald K., "Challenging ASEAN: The American Pivot in Southeast Asia,” East Asia Forum, 2013, http://www.eastasiaforum.org/2013/01/13/challenging-asean-the-american-pivotin-southeast-asia/ (Accessed, October 1, 2013) 
Espejo-Hermes, Jasmin, “Trends and Status of Fish Processing Technology,” in In Turbulent Seas: The Status of Philippine Marine Fisheries (Manilla: Department of Agriculture: Bureau of Fisheries and Aquatic Resources, 2004)

Fackler, Martin, "Japan is Flexing its Military Muscle to Counter Rising China," The New York Times, November 26, 2012, http://www.nytimes.com/2012/11/27/world/asia/japan-expands-its-regionalmilitary-role.html?pagewanted=all (Accessed September 20, 2013)

Fisher, Richard D. Jr. China's Military Modernization: Building for Regional and Global Reach (Stanford: Stanford University Press 2010)

Fisher, Richard D. Jr., "Defending the Philippines: Military Modernization and the Challenges Ahead," Center for a New American Security, 2012, http://www.cnas.org/files/documents/publications/CNAS_ESCS_bulletin3.pdf (Accessed September 10, 2013)

Goldman, Justin, “President Aquino’s Second Half: Minimum Credible Defense in Contested Waters?” The Jamestown Foundation China Brief 13 (2013), http://www.jamestown.org/uploads/media/cb_06_21.pdf (Accessed December 5, 2013)

Gomez, Edgardo D., "Is the Degradation of Resources in the South China Sea Reversible?: Approaches to Sustainable Management,” International Symposium of Protection and Management of the Coastal Marine Ecosystem, 2000, http://www.emecs.or.jp/2000thai-sympo/pdf/re-gomes.pdf (Accessed December 20, 2013)

Hatton, Celia, “China’s Xi Jinping: What Has He Achieved in His First Year," BBC News China, 2014, http://www.bbc.com/news/world-asia-china-26463983 (Accessed March 30, 2014)

Harlan, Chico, “Japan’s Prime Minister Shinzo Abe: Chinese Need for Conflict is 'Deeply Ingrained,”' The Washington Post, 2013, http://www.washingtonpost.com/world/japans-prime-minister-shinzo-abechinese-need-for-conflict-is-deeply-ingrained/2013/02/20/48adbc80-7a87-11e29a75-dab0201670da_story.html (Accessed September 20, 2013)

Heydarian, Richard Javad, “ADIZ Stirs Fears for South China Sea,” Asia Times, 2013, http://www.atimes.com/atimes/Southeast_Asia/SEA-01-061213.html (Accessed December 20, 2013)

Hong, Nong, UNCLOS and Ocean Dispute Settlement: Law and Politics in the South China Sea (New York: Routledge, 2012) 
Hong, Zhao, "China-Philippines Relations Stunted by South China Sea Dispute," Institute of Southeast Asian Studies SEAS Perspective 17 (2013), http://www.iseas.edu.sg/documents/publication/ISEAS\%20Perspective\%202013_ 17.pdf (Accessed November 11, 2013)

Hughes, Christopher W., Japan's Re-emergence as a 'Normal' Military Power, (London: Oxford University Press, 2004)

Hughes, Christopher W., Japan’s Remilitarization, (Oxon: Routledge, 2009)

Huu Dung, Nguyen, "Status of Fish Trade and Food Security in Viet Nam,” Food and Agriculture Organization, 2003, http://www.fao.org/docrep/006/y4961e/y4961e0k.htm (Accessed November 10, 2013)

Kang, Harnit, "Maritime Issues in South China Sea: A Survey of the Literature,” Institute of Peace and Conflict Studies, 2009, http://www.ipcs.org/pdf_file/issue/SR76-Harneet-Final.pdf (Accessed, October 13, 2013)

Keck, Zachary, “Made in China: A US-Japan-Philippines Axis?” The Diplomat, 2013, http://thediplomat.com/2013/06/made-in-china-a-us-japan-philippines-axis/ (Accessed October 5, 2013)

Keck, Zachary, “Japan’s Unveils “Aircraft Carrier in Disguise,”” The Diplomat, 2013, http://thediplomat.com/2013/08/japans-unveils-aircraft-carrier-in-disguise/ (Accessed September 26, 2013)

Khemakorn, Pakjuta, "Sustainable Management of Pelagic Fisheries in the South China Sea Region," United Nations - The Nippon Foundation, 2006, http://www.un.org/depts/los/nippon/unnff_programme_home/fellows_pages/fello ws_papers/khemakorn_0607_thailand.pdf (Accessed November 12, 2013)

Kurashige, Nanae, “Japan, Vietnam Agree on Defense Cooperation,” The Asahi Shimbun, 2011, http://ajw.asahi.com/article/behind_news/politics/aj2011102515718 (Accessed September 20, 2013)

Lague, David, “China’s Hawks Take the Offensive,” Reuters, 2013, http://www.reuters.com/investigates/china-military/ (Accessed December 5, 2013) 
Laserna Jr., Manuel J., "The Spratlys: Legal Basis of the Claim of the Socialist Republic of Vietnam,” Paracel and Spratly Islands Forums, 2008, http://paracelspratlyislands.blogspot.com/2008/01/legal-basis-of-vietnamsclaims.html (Accessed December 12, 2013)

Lee-Brago, Pia, “China Preparing to Seize Pag-asa Island,” The Philippine Star, 2014, http://www.philstar.com/headlines/2014/01/14/1278584/china-preparing-seizepag-asa-island-report (Accessed January 18, 2013)

Li Jinming and Li Dexia, "The Dotted Line on the Chinese Map of the South China Sea: A Note," Ocean Development \& International Law 34 (2003), Pg. 290, http://community.middlebury.edu/ scs/docs/Li\%20and\%20LiThe\%20Dotted\%20Line\%20on\%20the\%20Map.pdf (Accessed September 11, 2013)

Li Xiaokun and Ren Qi, “Tokyo Urged to End Militarism,” China Daily USA, 2014, http://usa.chinadaily.com.cn/world/2014-01/08/content_17221802.htm (Accessed, January 5, 2013)

Lozada, Bong, "Gazmin Calls on Superpowers to Stand up to China," Philippine Daily Inquirer, 2014, http://globalnation.inquirer.net/96905/gazmin-calls-on-superpowers-to-stand-upto-china (Accessed January 18, 2014)

Magdaraog Cordero, Jean, “Manila Formalizes 'West Philippine Sea’ Name,” Asia-Pacific Defense Forum, 2012, http://apdforum.com/en_GB/article/rmiap/articles/online/features/2012/10/24/phil ippines-sea-name (Accessed December 10, 2013)

Magdaraog Cordero, Jean, "Philippines Enhances Alliances with Japan, US,” Asia Pacific Defense Forum, 2012, http://apdforum.com/en_GB/article/rmiap/articles/online/features/2012/12/30/phil ippines-security-alliance (Accessed December 5, 2013)

Medeiros, Evan S., "Strategic Hedging and the Future of Asia-Pacific Stability," The Washington Quarterly 29:1 (2005)

Mitsuru Obe, Yuka Hayashi and Alexander Martin, "Japan Deploys Self Defense Forces to Aid Philippines," The Wall Street journal, 2013, http://online.wsj.com/news/articles/SB10001424052702303653004579209830690 172474 (Accessed December 1, 2013)

Moss, Trefor, “Japan’s New (Defensive) Attack Force,” The Diplomat, 2013, http://thediplomat.com/2013/11/japans-new-defensive-attack-force/?allpages=yes (Accessed September 26, 2013) 
Nguyen, Phuong, "Japan’s Pivot Should be Sustained: View from Southeast Asia,” cogitASIA: CSIS Asia House, 2013, http://cogitasia.com/japans-pivot-should-be-sustained-view-from-southeast-asia/ (Accessed October 5, 2013)

O’Rourke, Ronald, “Maritime Territorial and Exclusive Economic Zone (EEZ)

Disputes Involving China:

Issues for Congress," Congressional Research Service, 2013,

http://www.fas.org/sgp/crs/row/R42784.pdf (Accessed September 12, 2013)

Onodera, Itsunori, "Extra Press Conference by the Defense Minister,"

Ministry of Defense, 2013,

http://www.mod.go.jp/e/pressconf/2013/09/130917.html

(Accessed October 1, 2013)

Pajon, Celine, "Japan and the South China Sea: Forging Strategic Partnerships in a Divided Region," Institut Francais des Relations Internationales, Center for Asian Studies, 2013, http://www.ifri.org/?page=contribution-detail\&id=7555 (Accessed September 20, 2013)

Phan, Nga, “Shift as Vietnam Marks South China Sea Battle,” BBC News Asia, 2014, http://www.bbc.co.uk/news/world-asia-25709833 (Accessed January, 2014)

Poling, Gregory B., The South China Sea in Focus: Clarifying the Limits of Maritime Dispute,” Center for Strategic \& International Studies, 2013, http://csis.org/files/publication/130717_Poling_SouthChinaSea_Web.pdf (Accessed December 1, 2013)

Pyle, Kenneth B., Japan Rising: The Resurgence of Japanese Power and Purpose (New York: The Century Foundation, 2007)

Rajagopalan, Rajeswari P., "The Emerging Balance of Power in Asia: Conflict or Cooperation?” Centre for Land Warfare Studies 2009, http://www.claws.in/index.php?action=Claws\%20Paper (Accessed October 30, 2013)

Rehman, Iskander, "Deflecting the Assassin's Mace: The Pentagon’s New AirSea Battle Concept and its Strategic Relevance to India," Institute for Defense Studies and Analyses, 2010, http://idsa.in/issuebrief/AirSeaBattleConceptanditsRelevancetoIndia_irehman_07 0710 (Accessed November 12, 2013)

Reynolds, Isabel, “Japan Defense Budget to Increase for First Time in 11 Years," Bloomberg, 2013, http://www.bloomberg.com/news/2013-01-29/japan-s-defensespending-to-increase-for-first-time-in-11-years.html (Accessed October 1, 2013) 
Romero, Alexis, "Pinoy Fishermen Defy New Chinese Fishing Rules in Panatag Shoal," The Philippine Star, 2014, http://www.philstar.com/headlines/2014/01/26/1283092/pinoy-fishermen-defynew-chinese-fishing-rules-panatag-shoal (Accessed February 2, 2014)

Ross, Robert S., "Balance of Power Politics and the Rise of China:

Accommodation and Balancing in East Asia,"

Security Studies 15:3 (2006), http://www.tandfonline.com/doi/abs/10.1080/09636410601028206\#preview (Accessed November 1, 2013)

Rowan, Joshua P., "The U.S.-Japan Security Alliance ASEAN and the South China Sea Dispute,” Asian Survey 45:3 (2005)

Roy, Denny, "Stirring Samurai, Disapproving Dragon: Japan’s Growing Security Activity and Sino-Japan Relations," Asia-Pacific Center for Security Studies, 2003, http://www.jstor.org/discover/10.2307/30172610?uid=3739256\&uid=2129\&uid= 2\&uid=70\&uid=4\&sid=21101516703917 (Accessed November 5, 2012)

Roy, Denny, “China-Japan Relations: Cooperation Amidst Antagonism,” Asia-Pacific Center for Security Studies, 2004, http://www.apcss.org/Publications/SAS/AsiaBilateralRelations/ChinaJapanRelationsRoy.pdf (Accessed November 10, 2013)

Sasahara, Koji, “Philippines Backs Rearming Japan,” CNBC Asia-Pacific News, 2012, http://www.cnbc.com/id/100293527 (Accessed, October 12, 2013)

Sato, Yoichiro, "Southeast Asian Receptiveness to Japanese Maritime Security Cooperation,” Asia-Pacific Center for Security Studies, 2007, http://www.apcss.org/Publications/Maritime\%20security\%20cooperation\%20Japa n-SE\%20Asia\%20Sato.pdf (Accessed, October 12, 2013)

Sato, Yoichiro, "Japan Aid to the Philippines a Warning to China," East Asia Forum, 2013, http://www.eastasiaforum.org/2013/08/29/japan-aid-tothe-philippines-a-warning-to-china/ (Accessed, November 1, 2013)

Schuman, Michael, "China and Japan May Not Like Each Other, but They Need Each Other,” Time, 2013, http://world.time.com/2013/12/01/china-and-japan-may-notlike-each-other-but-they-need-each-other/ (Accessed December 5, 2013)

Shambaugh, David. Modernizing China's Military: Progress, Problems, Prospects (Los Angeles: University of California Press 2004) 
Shearer, Andrew, "Southeast Asia and Australia: Case Studies in Responding to China's Military Power," in Strategic Asia 2012-13: China's Military Challenge (Washington D.C.: The National Bureau of Asian Research, 2012)

Shiraishi, Masaya, Japanese Relations with Vietnam, 1951-1987 (Southeast Asia Program Publications: 1990)

Sisira Jayasuriya and Peter McCawley, The Asian Tsunami: Aid and Reconstruction After a Disaster (Cheltenham: Asian Development Bank Institute and Edward Elgar Publishing 2010)

Soeya, Yoshihida, Masayuki, Tadokoro and Welch, David A., Japan as a 'Normal Country'? (Toronto: University of Toronto Press, 2011)

Sonoda, Koji, “Japan’s New Defense Guidelines Stipulate Amphibious Force,” The Asahi Shimbun, 2013, http://ajw.asahi.com/article/behind_news/politics/AJ201310120038 (Accessed December 13, 2013)

Storey, Ian, Southeast Asia and the Rise of China: The Search for Security (New York: Routledge, 2011)

Storey, Ian, “Japan’s Growing Angst over the South China Sea," Institute of Southeast Asian Studies SEAS Perspective 20 (2013), http://www.iseas.edu.sg/documents/publication/ISEAS_Perspective\%202013_20. pdf (Accessed October 13, 2013)

Storey, Ian, "The South China Sea Dispute (Part 1): Negative Trends Continue in 2013,” The Jamestown Foundation China Brief 13:12 (2013), http://www.jamestown.org/uploads/media/cb_06_09.pdf (Accessed, December 5, 2013)

Takahashi, Toshiya, “Abe and a Japanese National Security Council,” East Asia Forum, 2013, http://www.eastasiaforum.org/2013/07/16/abe-and-ajapanese-national-security-council/ (Accessed December 12, 2013)

Thayer, Carlyle A., "Standoff in the South China Sea,” YaleGlobal, 2012, http://yaleglobal.yale.edu/content/standoff-south-china-sea (Accessed December 5, 2013)

Todore, Greg, "Vietnam's Military Growth Raising Eyebrows in the Region,” South China Morning Post, 2012, http://www.scmp.com/article/991004/vietnams-military-growth-raisingeyebrows-region (Accessed, October 15, 2013) 
Umeda, Sayuri, “Japan Article 9 The Constitution” Library of Congress (2006), http://www.loc.gov/law/help/JapanArticle9.pdf (accessed April 10, 2013)

Whitlock, Craig, "U.S. Eyes Return to Some Southeast Asia Military Bases," The Washington Post, 2012, http://www.washingtonpost.com/world/national-security/us-seeks-return-to-seasian-bases/2012/06/22/gJQAKP83vV_story.html (Accessed October 1, 2013)

Wood, Peter, "Why China Wants the SU-35," The Jamestown Foundation China Brief, 13:20 (2013), http://www.jamestown.org/uploads/media/China_Brief_Vol_13_Issue_20.pdf (Accessed September 12, 2013)

Xinbo, Wu, "The End of the Silver Lining: A Chinese View of the U.S.-Japanese Alliance,” The Washington Quarterly 29:1 (2005), http://www.brookings.edu/ /media/research/files/articles/2006/12/winter\%20chin a\%20xinbo/xinbo20060101.pdf (Accessed September 20, 2013)

Xuequan, Mu, “Chinese Military Lashes Out at Japanese Defense Documents," Xinhua, 2013, http://news.xinhuanet.com/english/china/2013-12/21/c_125893931.htm (Accessed December 22, 2013)

Yang, Jian, “China's Security Strategy Towards Japan: Perceptions, Policies and Prospects," The Centre for Strategic Studies, Victoria University of Wellington, 2001, http://www.victoria.ac.nz/css/docs/working_papers/wp17.pdf (Accessed November 5, 2013)

Yoshibara, Toshi and Holmes, James R., Red Star Over The Pacific: China's Rise and The Challenge to U.S. Maritime Strategy (Annapolis: Naval Institute Press, 2010)

Yueh, Linda, “Japanese Prime Minister Shinzo Abe Urges Asia Military Restraint,” BBS News Asia, 2014, http://www.bbc.co.uk/news/world-asia-25851960 (Accessed, January 23, 2013)

Zhu Chao and Feng Wuyong, “'Abe-Military' on State, Region on Alert,” Xinhua, 2013, http://news.xinhuanet.com/english/world/2013-12/17/c_125875313.htm (Accessed December 22, 2013)

Zhaokun, Wang, “Tokyo Unveils New Carrier,” Global Times, 2013, http://www.globaltimes.cn/content/802056.shtml\#.UuhERPnTmUl (Accessed September 26, 2013) 